\title{
Exploring the potential of special music education in child development
}

Citation for published version (APA):

Dumont, E. (2021). Exploring the potential of special music education in child development: a case study of special music education in the Netherlands. [Doctoral Thesis, Maastricht University]. Ridderprint. https://doi.org/10.26481/dis.20210210ed

Document status and date:

Published: 01/01/2021

DOI:

10.26481/dis.20210210ed

Document Version:

Publisher's PDF, also known as Version of record

\section{Please check the document version of this publication:}

- A submitted manuscript is the version of the article upon submission and before peer-review. There can be important differences between the submitted version and the official published version of record.

People interested in the research are advised to contact the author for the final version of the publication, or visit the DOI to the publisher's website.

- The final author version and the galley proof are versions of the publication after peer review.

- The final published version features the final layout of the paper including the volume, issue and page numbers.

Link to publication

\footnotetext{
General rights rights.

- You may freely distribute the URL identifying the publication in the public portal. please follow below link for the End User Agreement:

www.umlib.nl/taverne-license

Take down policy

If you believe that this document breaches copyright please contact us at:

repository@maastrichtuniversity.nl

providing details and we will investigate your claim.
}

Copyright and moral rights for the publications made accessible in the public portal are retained by the authors and/or other copyright owners and it is a condition of accessing publications that users recognise and abide by the legal requirements associated with these

- Users may download and print one copy of any publication from the public portal for the purpose of private study or research.

- You may not further distribute the material or use it for any profit-making activity or commercial gain

If the publication is distributed under the terms of Article $25 \mathrm{fa}$ of the Dutch Copyright Act, indicated by the "Taverne" license above, 
Exploring the potential of special music education in child development: a case study of special music education

in the Netherlands 
ISBN: 978-94-6416-313-1

Cover and lay-out: Publiss - www.publiss.nl

Printing: Ridderprint B.V - www.ridderprint.nl 


\section{Exploring the potential of special music education in child development: a case study of special music education in the Netherlands}

PROEFSCHRIFT

Ter verkrijging van de graad van doctor aan de Universiteit Maastricht, Op gezag van de Rector Magnificus, Prof.dr. Rianne M. Letschert, Volgens het besluit van het College van Decanen, In het openbaar te verdedigen op woensdag 10 februari 2021 om 13.00 uur

door 


\section{Promotores}

Prof. dr. F.J.M. Feron

Prof. dr. S.A.H. van Hooren

Open Universiteit

\section{Copromotor}

Dr. E.V. Syurina

Vrije Universiteit Amsterdam

\section{Beoordelingscommissie}

Prof. dr. T.A.M.J. van Amelsvoort (Voorzitter)

Prof. dr. J. Jolles

Vrije Universiteit Amsterdam

Prof. dr. X.M.H. Moonen

Universiteit van Amsterdam

Prof. dr. C.M. van Heugten 
Aan Björn, Olivia en Nina 


\section{Table of contents}

Chapter $1 \quad$ General introduction

Chapter 2 Music interventions and child development: a critical review and further directions

Chapter $3 \quad$ Special Music Education:

A Prelude to a New Perspective?

Chapter 4 Special music education and executive functioning: design of a practice-based research

Chapter 5 Beyond the sound of music: an observational study exploring the challenges of music education

Chapter 6 Exploring the effect of special music education on executive functioning in children with special educational needs:

a pilot study

Chapter 7

General discussion

Summary

Samenvatting

Valorisatie

Dankwoord

Curriculum Vitae

195

Publications 
CHAPTER 1

General introduction 


\section{Introduction}

Music is considered an integral part of all human cultures (Schulkin \& Raglan, 2014). Furthermore, music was considered an important element in education within Plato's era (427-347 BC) (Stamou, 2002) and presently, music is a regular subject included in the curriculum from preschool to secondary education in most countries. Besides benefits relating to music education itself, research suggests that it may also have beneficial effects on other, non-musical domains (e.g., academic achievement and cognitive functioning) (Gills \& Rickard, 2012).

School-based music education may not only benefit primary school children in domains other than musical skills (Jascke, Honing \& Scherder, 2018), it may also benefit children with special educational needs. Since music can be adapted to the child's strengths and weaknesses and learning style, it may play an important role in meeting his/her educational needs. Moreover, these children appear to benefit from an inclusive learning environment that recognises not only their musical abilities and difficulties, but also their unique learning issues and specific educational goals. In this dissertation, the role played by a specific type of music education for children with special educational needs, namely special music education (SME), on stimulating the development of these children will be explored.

\section{Children with special educational needs}

The term 'children with special educational needs' refers to children with learning and/or behavioural problems or disabilities that need additional educational support compared to most children of the same age. These children generally have difficulties with learning, having their own learning path for several subjects, and/or they have difficulties with the required level of independence, which means that they require more intensive help to learn the skills they need. Their learning performance may be disturbed by a wide range of problems. Children may have difficulties with processing visual/auditory information efficiently and quickly. These processing problems can interfere with learning skills like reading or math or contribute to (specific) learning problems like dyslexia, dyscalculia or auditory processing disorder (Keil, Miller \& Cob, 2006). Learning problems may also be explained by developmental disabilities, such as autism or language disorder. Furthermore, emotional problems related to the home situation or school can lead to a gap between the child's potential and 
actual achievement for a longer or shorter time. A child may also have an intellectual disability and may therefore be unable to follow the subject matter, which may lead to a reduced learning performance. Besides, children with special educational needs may (also) show behaviour problems, and/or struggle with themselves and others, because of which they learn insufficiently. Learning problems rarely occur in isolation and often coexists with other problems, adversely affecting a child's educational achievement.

Compared to typically developing children, children with special educational needs are a more heterogeneous group, differing greatly in their learning abilities and challenges faced in the classroom. In order to maximize the child's learning potential and optimize his/her learning environment, additional educational support is often required specifically attuned to their educational needs. In the Netherlands, there is a continuum of educational support available, ranging from support offered in regular education to (temporary) placement in special education.

\section{The Dutch special primary educational system}

The Dutch special education policy is, like many other countries, aimed at Inclusive Education [in Dutch: "Passend onderwijs"] (Ainscow \& Cesar, 2006), aspiring to educate as many children with (learning) disabilities in regular education as possible. A child is admissible to special primary education only if the child's needs fall beyond the resources available to the regular primary school (Rijksoverheid, n.d.). In 2010-2011, more than 42.000 children received special primary education. Along with the implementation of Inclusive Education in 2014, there has been a steady decline in the number of children in special primary education, from nearly 37,000 in 2014-2015 to nearly 34,000 in 20172018 (CBS, 2019). In Europe, estimates placed the number of children in special primary education at 3,4000,000 in 2010-2011. However, this estimate should be interpreted with caution as there is no commonly agreed definition of 'special educational needs' in use across the EU (European Commission, 2012).

In Dutch special primary education, the learning objectives, unlike in regular primary education, are more attuned to the individual child. The children are taught in a more structured and supportive environment than children in a regular primary school and there are small classes to optimally support the children. They also get more time to complete primary school (until age 14) (Rijksoverheid, n.d.). In the Netherlands, 
special primary education is divided into 'speciaal onderwijs' [Dutch abbreviation: SO] and 'speciaal basisonderwijs' [Dutch abbreviation: SBO]. Education in SO schools is organized based on the type of special needs. There are four different types of need - visual impairment, hearing/speech impairment, cognitive/physical disabilities and serious behavioural or psychiatric issues. The children in SO schools often do not follow the regular curriculum; instead, they are provided with a differentiated and adapted educational program. Education in SBO schools is considered as the lighter form of special primary education for children, with less severe problems compared to the problems experienced in SO. This type of education is especially meant for children who have learning difficulties, low IQ scores, and/or behavioural problems. The children follow the regular curriculum and have the same key objectives as regular primary schools. The need for special primary education services as well as the (in) capacity to address the needs of a child in regular primary education are factors used to determine the sort of support instead of the behavioural/learning disorder or problems per se. This means that a child with ADHD, for example, is eligible for either special primary education (SBO or SO) or regular primary education with additional support, depending on characteristics of the child and the setting.

\section{A broader perspective on the role of music in education}

In addition to the (conventional) didactic approach, evidence suggests that a child's educational needs may also be supported through music education. Music education has a positive impact on the child's musical development. Furthermore, it contributes to the development of their motor skills, their hearing, and helps to increase their sense of rhythm and to improve their (singing) voice, thereby improving their ability to analyse sounds and to discern meaning from what they hear (SLO, n.d.). Besides improving musical abilities, studies have indicated that music training and education may have a wider impact on a child's cognitive, social and emotional development. Studies have shown that music training and education may have academic benefits (Petress, 2005; Schlaug, Norton, Overy, \& Winner, 2005), can boost processes such as reasoning ability (Forgeard, Winner, Norton, \& Schlaug, 2008), cognitive development (Piro \& Ortiz, 2009), motivation to learn (Portowitz \& Klein, 2007), fine motor skills (Costa-Giomi, 2005), and social skills, such as emotion recognition (Lima \& Castro, 2011) and empathy and collaboration (Hallam, 2010). It has also been shown to enhance cognitive functions, such as attention and memory (Ho, Cheung, \& Chan, 
2003; Strait, Parbery-Clark, Hittner, \& Kraus, 2012). These functions, also called executive functions, receive much attention when the effects of music in child development are considered.

A potential explanation for such non-musical findings could be that engagement in music and musical activities provides multisensory stimulation, thereby activating widely distributed networks of subcortical and cortical brain areas that mediate general cognitive, motor and language function (Zimmerman \& Lavah, 2012). Musical activities imply the activation of visual, auditory, tactile and motor systems, among others, thereby (implicitly) engaging and appealing to many of the sensory strengths and/or needs of a child. It may also involve memorization, as a child has to be able to play the correct notes on an instrument or recall the lyrics of a song. These processes may benefit overall memory. In addition, musical activities may stimulate the child's ability to pay attention, which is essential for school performance (Neville et al., 2008). Music education in school can be highly valuable to children with special educational needs as both activities and the role of the child can be adapted to meet their individual strengths and needs. Children with special educational needs usually perform worse academically than regular students, and music lessons may enable them to feel successful and to participate equally in/at the same level of a group rather than standing out in a negative way (Chamberlain \& Gallegos, 2006). Musical activities are a joint effort, supporting the processes involved in teamwork and working towards shared goals. Furthermore, the joy that music brings to the child can motivate him/ her to participate actively. This motivation may then be transferred to other, nonmusical learning situations (Portowitz \& Klein, 2007). Music can be used to improve communication and interaction skills as well (Bunt, 2003), which might be helpful for children who have learning, emotional, and/or behavioural difficulties, particularly for children with autistic spectrum disorder (Chamberlain \& Gallegos, 2006).

Research on the effect of music lessons on children with special educational needs has (up to now) mainly concentrated on music therapy or music interventions aimed at specific problems (Legutko \& Trissler, 2012; Kim, Wigram \& Gold, 2008). Although the results suggest that music interventions and music therapy provided to children with special educational needs may result in development outside of the field of music, little is known about the use of music as a potential resource for children in special primary education in the Netherlands. 


\section{Special music education}

In Dutch primary school curriculum, music education is not generally placed within the framework of educational aims. There is, however, one particular type of music education that provides opportunities for music to be used as a device to stimulate a child's developmental and learning goals. In the Netherlands, this form of music education is known as special music education (SME) (Rutten \& Stuijts, 2014). SME is provided in several special primary schools and is focused on helping the child to be able to achieve musical goals together with stimulating a child's cognitive, motor, sensory, and/or emotional skills. The teaching of SME requires a broad range of skills and competencies, drawing on a combination of musical, (ortho)pedagogical and (ortho)didactic knowledge as well as interpersonal skills. In the Netherlands, these competencies are taught during a two-year specialization course at the Maastricht academy of music, which is aimed at teaching music in special education. Systematic observations during SME lessons enables an SME teacher to gain more insight into a child's musical and non-musical behaviour and to define individual as well as class learning goals. These observations are considered as the starting point for tailoring musical activities, teaching methodology, attitude towards students, and level of participation according to the diverse educational needs of the individual child as well as the class (Rutte \& Stuijts, 2014). Special music education should not be confused with music therapy. Though music is the common denominator, music therapy is focused on using music to facilitate a change in physical, psychological, cognitive and/ or social functioning. Provided by a trained therapist, the purpose of music therapy is to achieve therapeutic, non-musical goals, but not to teach musical skills. Special music education, on the other hand, is under the education heading. Provided by a trained teacher, it is integrated in a general curriculum and typically does address both the musical and non-musical development of a child within his/her ability level.

Central to the practice of SME is the use of music as an accessible medium for children to non-verbally express themselves, to make choices, giving them a sense of autonomy and to stimulate (non-)musical learning. Children with special educational needs may quickly feel unable to perform a musical task because of a lack of selfconfidence. By letting a child, for example, choose between different instruments to play, or experiment with different kinds of music, he/she may start to feel confident in who he/she is and/or more confident to perform in front of others. SME may boost the child's ability to pay attention, for example through active listening or remain focused 
on a (adapted) musical task for some time. Likewise, it may also help strengthen memory skills through the learning and repetition of songs or recognizing the cue to begin singing or performing. Movement to music or performing on (carefully selected) instruments during SME lessons may also help children build motor skills. The types of musical activities and the teaching approach in SME lessons also provide opportunities to interact with other children; working and musically performing together as a group enables the child (to learn) to cooperate and collaborate which may boost their self-esteem and social skills.

In educational practice, SME teachers and students report that SME seems to have a positive influence on children with special educational needs. In view of these experiences, as well as research findings on the wider potential of music, SME may be beneficial to children with special educational needs. However, there remains a gap within scientific evidence in the field of special music education.

Many interrelated factors can influence the practice as well as the investigation of SME, including child characteristics, teacher characteristics, the learning environment and the music, as is illustrated by the following example.

Jeffrey is a six-year-old boy who just started special education. In the SME lessons, he is experienced as a dominant, somewhat impulsive boy. He cannot deal with criticism. Whenever the SME teacher makes a remark on his behaviour, he gets defensive and says that he does not understand what the big deal is. He is also very creative and likes to be in the spotlight. He loves to move to music and to sing songs. However, if tasks are assigned to small groups during the lesson, he cannot adapt. Classmates grow increasingly irritated by his behaviour. The SME teacher decides to do a series of five observations to have a better understanding of his behaviour. Based on these observations, it became obvious that Jeffrey is a smart child who has difficulties following instructions and who does not always pay attention to what is being explained. The classroom teacher describes him as a smart but distracted, creative and visually oriented student; his academic performance is poor. Despite his low rank within the peer group, he behaves as though he is in control.

The SME teacher develops a plan for the music lessons intended to have a positive influence on his behaviour. With regard to teaching methods, the SME teacher decides to present extra tasks to him to provide a wide variety of short movement activities, that become increasingly longer. He also decides to present the lessons at a lively pace in order to prevent him becoming distracted or taking the lead. Instructions, both verbally and visually, are 
presented in a calm way, enabling Jeffrey to follow these instructions and to understand what is expected of him.

With regard to musical domains, the SME teacher decides to work on the domains of movement and listening. During one task, all children have to move around the room as he plays the guitar. When he stops, they must freeze. Before they start, the teacher gives clear instructions to the group; they are not allowed to run. Starting with a short time frame allows Jeffrey's attention to outlast the task gives him a sense of success in that task. The teacher makes this task more challenging by creating longer stops while observing his reaction. In another task, the teacher plays the drums while all children play small percussion instruments. Whenever the teacher plays soft or loud or suddenly stops playing, he expects the children to do likewise. Next, several children, including Jeffery, take a turn in playing the drums and the group has to act accordingly. As a variation of the task, the dynamics are more exaggerated and/or children work in pairs, taking turns in leading and following. The teacher can let Jeffrey work together with another, quiet child. Only if this goes well, the teacher may choose to work in groups again. On another occasion, he decides to work with the child himself while briefly mirroring his behaviour during tasks.

As can be seen in the example, many factors, e.g., child behaviour, teacher attitude, class dynamics, type of task, play a role in this situation, both separately and collaboratively. Consideration of all relevant factors is required in order to enhance our understanding of relevant key concepts of SME lessons as well as the impact on the child's functioning. The dynamic biopsychosocial model, providing such a holistic view, is used as a point of reference.

The dynamic biopsychosocial model of health (Lehman, David \& Gruber, 2017) can be viewed as an extended version of the biopsychosocial model (BPS) developed by Engel (1977). The BPS model considers three factors - biological (physical factors), psychological (cognitive, emotional and behavioural factors) and social (social contacts, social support) - and their reciprocal influence to understand health and illness. The dynamic biopsychosocial model of health expands on the BPS model by also considering contextual aspects (broad-range culture, values) and the way these four components interact with each other and influence each other as well as taking into consideration that these components can change over time (Lehman et al., 2017). Leaving the framework of the model intact, we adapted the content of the proposed factors to suit the specific characteristics of SME. The model is represented in Figure 1. 
The biological domain represents the child's physical skills and circuits of brain areas involved in musical learning, from primary senses, to motor functions, to association networks such as multisensory integration in networks responsible for cognitive functions. Besides a strong biological component, brain development is influenced by the social and physical environment of the child (Evans, 2006).

The psychological domain represents a variety of cognitive processes that are involved in SME lessons. Among these are coping styles, expectations, motivation and executive functions. These functions refer to a set of cognitive abilities that control and regulate other abilities and behaviours (Hallam, Cross \& Thaut, 2011). These functions play an important role in learning in school and social interaction (Diamond, 2016).

The interpersonal domain represents the interactions between an SME teacher, the (individual) child (ren) and the music. These interactions cannot be seen as isolated events. Research has shown that teacher-child relationships can influence the child's interactions with peers in the classroom (Ladd, Birch \& Buhs, 1999) as well as classroom climate (Pianta, Steinberg \& Rollins, 1995), which, in turn, can impact a child's academic achievement and learning motivation among other aspects (Zedan, 2010). Both the child and the SME teacher interact with the music itself. By exploring (independently or socially) with sounds, pitches, tones, and rhythms, a child is able to create his/her own musical experience and to express his/her feelings.

Contextual factors represent components both inside and outside the SME lessons. Factors inside the SME lessons may include classroom dynamics, i.e. the interaction between children and the SME teacher in the music classroom, as well as musical material, i.e. the materials and equipment needed for an SME lesson and the setting i.e. the available space to allow for an SME lesson. External factors may include a child's friends and the parent-child relationship.

It can be seen from the model that development in one domain influences and is influenced by the development in the other domains. For example, the development of cognition (psychological domain) is dependent on the maturation of neural networks in the brain (biological domain) (London, 2011). Problems in cognitive development can cause problems in getting along with other children in the class (interpersonal domain) and/or might result in emotional difficulties when struggling to find social support (contextual factors), which can impact a child's motivation (psychological domain).

This adapted model allows for exploring in more depth both (a) the relevant key 
concepts and their interaction, and (b) their potential impact on the child's functioning within the context of SME lessons. Since this thesis is not intended to explore neurological aspects involved in music making and music education, the biological domain will not be considered. Instead, the focus will be on the psychological and interpersonal domain.

\section{SME lesson}

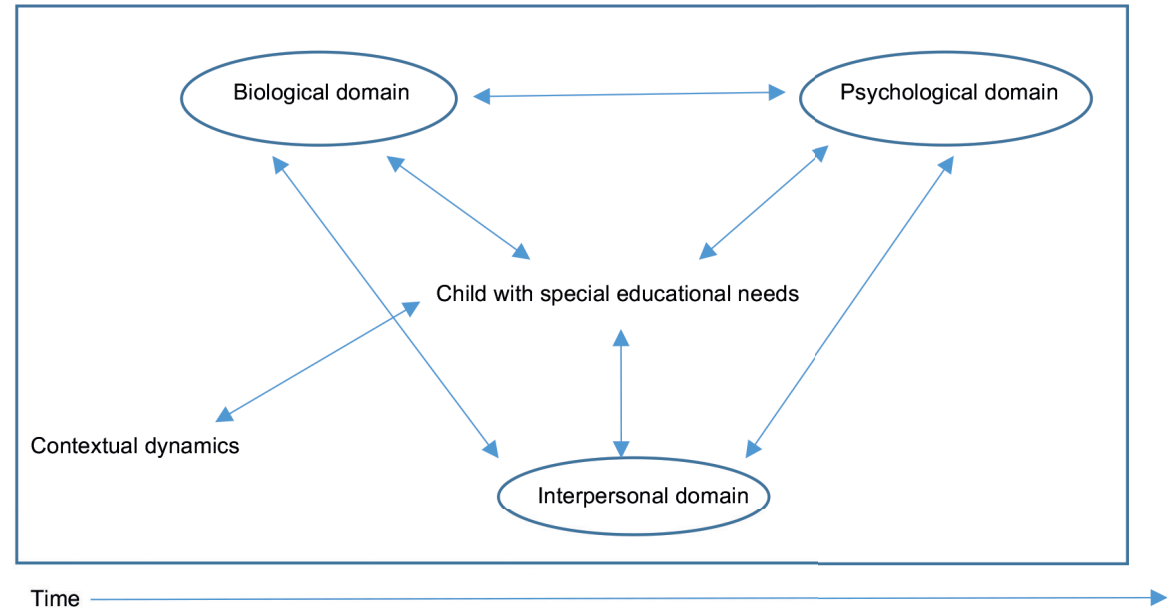

Figure 1 Adapted from the dynamic biopsychosocial model (Lehman et al., 2017) showing the interaction of biological, psychological and interpersonal factors of SME lessons.

\section{Aim of this thesis}

As a first step in exploring the potential impact of special music education, this thesis aims to provide insight into what constitutes these SME lessons and their potential in stimulating development in children following these lessons from a practice-based perspective. Outcomes will contribute to a better understanding of the significance of SME within the special educational context. In order to decide which area(s) SME could have a beneficial impact on, the study was conducted in two phases. The first phase involved conducting a literature review as well as focus groups consisting of SME students and SME teachers. In the second phase of the research, which involved a quasi-experimental study conducted in special primary and regular primary schools, the impact of special music education on executive functioning was explored. By collecting neuropsychological and behavioural data on children and conducting 
observations of music lessons as well, we were able to integrate the qualitative and quantitative information to provide insight into and further understanding of the value of special music education.

\section{Research questions}

In this thesis, the following questions are addressed:

1. What are the effects of music training and education on learning and development of children, described in the literature?

2. What are methods and lines of reasoning used in special music education and what potential may it hold for children with special educational needs?

3. How is special music education and regular music education offered in (special) primary schools in the Netherlands presently and what factors influence this provision?

4. What is the potential of special music education on executive functioning in children with special educational needs, compared to regular music education?

\section{Structure of this thesis}

Chapter 2 describes the literature review, summarizing the effects of music training and education on learning and development in primary school-aged children. The methodological quality of the included studies as well as possible influencing factors that might contribute to the outcome(s) are reviewed.

Chapter 3 presents the findings of two focus groups, formed of SME teachers and SME students to answer the question: 'What are methods and lines of reasoning used in SME and what potential may it hold for children with special educational needs?' This qualitative study aims to explore the concept of SME in more detail and the potential it may hold for children in special primary education. In this chapter, both focus groups discuss their (shared) experiences, observed effects, underlying views as well as their role therein. The results are input for chapter 4, 5 and 6.

Chapter 4 describes the design of a quasi-experimental study. It consists of a mixed method design, in which both quantitative and qualitative methods are used to explore 
the effect of SME on executive functioning in children with special educational needs within the complexity of the school context. The theoretical and practical implications of the proposed design are discussed.

Chapter 5 addresses the question 'How is special music education and regular music education offered in (special) primary schools in the Netherlands nowadays and what factors influence this provision?' This study focusses on the current situation of music education and identification of good practices. Children and teachers in firstgrade and/or second-grade classes of three special primary schools and two regular primary schools are observed during the music lessons on several occasions during one school year to gather data around content of music lessons, teacher behaviour and teacher-child interactions as well as the context in which they occurred.

Chapter 6 addresses the question: 'What is the effect of special music education on executive functioning in children with special educational needs, compared to regular music education?'. The aim of this study is to investigate if special music education benefits the development of executive functioning using a quasi-experimental design. Attention, working memory and flexibility were examined using neuropsychological tests in 6-9 year old children who received special music education as part of the school curriculum versus those who received regular music education. Parents and teachers of participating children fill out questionnaires asking about (executive function) behaviour of the child in the school and home environment.

Chapter 7 summarizes and discusses the main findings of this study. The qualitative and quantitative results will be integrated and the effects as well as the significance of special music education will be discussed as well. Finally, recommendations for further research and practice will be presented. 


\section{References}

Ainscow, M., \& César, M. (2006). Inclusive education ten years after Salamanca: Setting the agenda. European Journal of Psychology of Education, 21(3), 231-238.

Bunt, L. (2003). Music therapy with children: a complementary service to music education? British journal of music education, 20(02), 179-195. DOI: 10.1017/S0265051703005370

Chamberlain, S. P., \& Gallegos, J. (2006). Judith A. Jellison: Music and Children with Special Needs. Intervention in School and Clinic, 42(1), 46-50. DOI: 10.1177/10534512060420010801

Centraal Bureau voor de Statistiek. (2019). Onderwijsinstellingen; grootte, soort, levensbeschouwelijke gronds/ag. https://opendata.cbs.nl/statline/\#/CBS/nl/dataset/03753/table?dl=1063F

Costa-Giomi E. (2005). Does music instruction improve fine motor abilities? Annals of the New York Academy of Sciences, 1060: 262-264. DOI: 10.1196/annals.1360.053

Diamond, A. (2016). Why improving and assessing executive functions early in life is critical. Executive function in preschool-age children: Integrating measurement, neurodevelopment, and translational research, 11-43. DOI: $10.1037 / 4797.00$

Engel, G. L. (1977). The need for a new medical model: A challenge for biomedicine. Science, 196, 129-136. DOI: 10.1126/science.847460

Evans, G. W. (2006). Child development and the physical environment. Annual Review of Psychology, 57, 423-451. DOl:10.1146/annurev.psych .57.102904.190057

European Commission (2012), 'Special Needs Children and Disabled Adults Still Getting a Raw Deal from Education, says report', Commission Press Release.

Forgeard, M., Winner, E., Norton, A., \& Schlaug, G. (2008). Practicing a musical instrument in childhood is associated with enhanced verbal ability and nonverbal reasoning. PLOS ONE, 3(10), e3566. DOl:10.1371/journal.pone.0003566

Gill, A., \& Rickard, N. S. (2012). Non-music benefits of school-based music training. In N. S. Rickard \& K. McFerran (Eds.), Lifelong engagement with music: Benefits for mental health and well-being (pp.57-72). New York, NY: Nova Science Publishers.

Jaschke, A. C., Honing, H., \& Scherder, E. J. (2018). Longitudinal analysis of music education on executive functions in primary school children. Frontiers in neuroscience, 12, 103. DOI: 10.3389/ fnins.2018.00103

Hallam, S. (2010). The power of music: Its impact on the intellectual, social and personal development of children and young people. International Journal of Music Education, 28(3), 269-289. DOI: 10.1177/0255761410370658

Hallam, S., Cross, I., \& Thaut, M. (Eds.). (2011). Oxford handbook of music psychology. Oxford University Press.

Ho, Y. C., Cheung, M.C., \& Chan, A. S. (2003). Music training improves verbal but not visual memory: cross-sectional and longitudinal explorations in children. Neuropsychology, 17(3), 439. DOI: 10.1037/0894-4105.17.3.439

Keil, S., Miller, O., \& Cobb, R. (2006). Special educational needs and disability. British Journal of Special Education, 33(4), 168-172. DOI: 10.1111/j.1467-8578.2006.00435.x 
Kim, J., Wigram, T., \& Gold, C. (2008). The effects of improvisational music therapy on joint attention behaviors in autistic children: A randomized controlled study. Journal of Autism and Developmental Disorders, 38, 1758-1766. DOI: 10.1007/s10803-008-0566-6

Ladd, G. W., Birch, S. H., \& Buhs, E. S. (1999). Children's social and scholastic lives in kindergarten: Related spheres of influence?. Child development, 70(6), 1373-1400.

Legutko, R. S., \& Trissler, T. T. (2012). The effects of background music on learning disabled elementary school students' performance in writing. Current Issues in Education, 15(1), 1-8.

Lehman, B. J., David, D. M., \& Gruber, J. A. (2017). Rethinking the biopsychosocial model of health: Understanding health as a dynamic system. Social and personality psychology compass, 11(8), e12328. DOI: 10.1111/spc3.12328

Lima, C. F., \& Castro, S. L. (2011). Speaking to the trained ear: Musical expertise enhances the recognition of emotions in speech prosody. Emotion, 11(5), 1021-1031. DOI: 10.1037/ a0024521

London, M. (Ed.). (2011). The Oxford handbook of lifelong learning. New York, NY: Oxford University Press Inc.

Neville, H., Andersson, A., Bagdade, O., Bell, T., Currin, J., Fanning, J., Klein, S., Lauinger, B., Pakulak, E., Paulsen, D., Sabourin, L., Stevens, C., Sundborg, S., \& Yamada, Y. (2008). Effects of music training on brain and cognitive development in underprivileged 3-to 5-year old children: Preliminary results. In: C. Asbury \& B. Rich (Eds.), Learning, arts, and the brain: The Dana Consortium report on arts and cognition (pp.105-116). New York/Washington, DC: Dana Press.

Petress, K. (2005). The importance of music education. Education, 126(1), 112-115.

Pianta, R. C., Steinberg, M. S., \& Rollins, K. B. (1995). The first two years of school: Teacherchild relationships and deflections in children's classroom adjustment. Development and psychopathology, 7(2), 295-312. DOI: 10.1017/S0954579400006519

Piro, J. M., \& Ortiz, C. (2009). The effect of piano lessons on the vocabulary and verbal sequencing skills of primary grade students. Psychology of Music, 37(3), 325-347. DOI: $10.1177 / 0305735608097248$

Portowitz, A., \& Klein, P. S. (2007). MISC-MUSIC: a music program to enhance cognitive processing among children with learning difficulties. International Journal of Music Education, 25(3), 259271. DOI: $10.1177 / 0255761407087263$

Rijksoverheid. (n.d.). Speciaal onderwijs. https://www.rijksoverheid.nl/onderwerpen/passendonderwijs/speciaal-onderwijs

Rutten, M., \& Stuijts, M. (2014). Muziekstragie [Music strategy]. Maastricht, Nederland: Conservatorium Maastricht.

Schlaug, G., Norton, A., Overy, K., \& Winner, E. (2005) Effects of music training on the child's brain and cognitive development, Annals New York Academy of Science, 1060, 219-230. DOI: 10.1196/annals.1360.015

Schulkin, J., \& Raglan, G. B. (2014). The evolution of music and human social capability. Frontiers in neuroscience, 8, 292. DOI: 10.3389/fnins.2014.00292

SLO. (n.d.). Leerplankader kunstzinnige oriëntatie. http://kunstzinnigeorientatie.slo.nl/ 
Stamou, L. (2002). Plato and Aristotle on music and music education: Lessons from ancient Greece. International Journal of Music Education, (1), 3-16. DOI: 10.1177/025576140203900102

Strait, D. L., Parbery-Clark, A., Hittner, E., \& Kraus, N. (2012). Musical training during early childhood enhances the neural encoding of speech in noise. Brain and language, 123(3), 191-201. DOI: 10.1016/j.bandl.2012.09.001

Zedan, R. (2010). New dimensions in the classroom climate. Learning Environments Research, 13(1), 75-88. DOI: 10.1007/s10984-009-9068-5

Zimmerman, E., \& Lavah, A. (2012). The multisensory brain and its ability to learn music. Annuals of the New York Academy of Sciences. Issue: The Neurosciences and Music IV: Leaning and Memory, 1252, 179-184. DOI: 10.1111/j.1749-6632.2012.06455 


\section{CHAPTER 2}

\section{Music interventions and child development: a critical review and further directions}

\section{Published as:}

Dumont, E., Syurina, E. V., Feron, F. J., \& van Hooren, S. (2017). Music interventions and child development: a critical review and further directions. Frontiers in 


\section{Abstract}

Research on the impact of music interventions has indicated positive effects on a variety of skills. These findings suggest musical interventions may have further potential to support educational processes and development of children. This paper reviews the latest evidence on the effect of musical interventions on the development of primary school-aged children. Four electronic databases were searched from January 2010 through June 2016 using music, music instruction, music education, music lesson, music training, development, child, student, and pupil as key words for the search. Two reviewers independently evaluated the studies to determine whether they met the stated inclusion criteria. Studies were compared on study setup, methodological quality, intervention components, outcome variables, and efficacy. A review of these selected studies ( $n=46$ ) suggested beneficial effects of music intervention on development of children, although clear conclusions cannot be drawn. Possible influencing factors that might contribute to the outcome of intervention are reviewed and recommendations for further research are made. 


\section{Introduction}

Music interventions are often said to have an influence on motor, language, social, cognitive, and academic abilities (Ho et al., 2003; Costa-Giomi, 2004; Schellenberg, 2004; Forgeard et al., 2008; Standley, 2008; Jentschke \& Koelsch, 2009; Southgate \& Roscigno, 2009; Yazejian \& Peisner-Feinberg, 2009; Strait et al., 2010). Music may play an important role in meeting a child's educational needs as it provides a means of self-expression, giving the child an outlet for feelings and emotions. Music, aside from being a source of enjoyment, is also a means of communication with others (Suthers \& Niland, 2007). Music may expose the child to challenges and multi-sensory experiences which enhance learning abilities and encourage cognitive development. In particular, music can also engage cognitive functions, such as planning, working memory, inhibition, and flexibility. These functions are known as executive functions (EF). Although there is no consensus on conceptualization, there is agreement on the complexity and the importance of EF for learning and development (Gioia et al., 2000). Music education may be a promising tool in improving EF as it activates multiple cortical and subcortical brain areas, including the prefrontal cortex, which is linked to EF (Särkämö et al., 2014). Musical interventions may become an appealing approach for schools that are increasingly facing a challenge of supporting education processes and development of children with varied degrees of learning and behavioural difficulties. However, before an extended use can be introduced into practice, we need to have a clearer, more systematic understanding of the known effects musical interventions have. The current study builds on the results of previous reviews of literature examining the impact of music training and education including, among others, those of Jaschke et al. (2013), Cogo-Moreira et al. (2012), Besson et al. (2011), Maloy \& Peterson (2014), and Miendlarzewska \& Trost (2014). Jaschke et al. (2013) found mixed evidence of far transfer effects between music education and other cognitive skills. Cogo-Moreira et al. (2012) aimed to review RCTs to investigate the effectiveness of music education on reading skills in children and adolescents with dyslexia but were unable to find such studies. In a meta-analysis, Maloy \& Peterson (2014) concluded that there was a minimal effect of music as an intervention to increase task performance in children and adolescents with ADHD. Miendlarzewska \& Trost (2014) found that musical training in childhood has a positive impact on many cognitive functions and is associated with neuroplastic changes in brain structure and function. The transfer of training from music to speech was evaluated by Besson et al. (2011), who pointed to positive transfer of training effects from musical expertise 
to speech processing. When interpreting the results, it is important to take into consideration that these reviews in general yielded mixed results and were limited in their focus: specific skills (Cogo-Moreira et al., 2012), a specific developmental domain (Miendlarzewska \& Trost, 2014), specific designs and age groups (Cogo-Moreira et al., 2012; Jaschke et al., 2013), or a specific target group (Maloy \& Peterson, 2014). Bearing these in mind, the purpose of this article is to provide a comprehensive summary of the existing research in the field by collecting and analysing the latest evidence on the effect of music interventions across different domains of development of the primary school-aged children. It aims to report on the effectiveness of a broad range of music interventions, describe relevant contextual factors, to evaluate the general level and quality of evidence in the field and to provide implications for future research.

\section{Methods}

Due to a broad scope of this study, we decided to do a systematic search and a "critical review," which aims to "extensively research the literature and critically evaluate its quality" (Grant \& Booth, 2009). Several steps were taken in order to ensure high scientific quality of the work. Search Procedure The search for relevant articles was conducted via three routes. First, PubMed, EMBASE (Ovid), Psyclnfo, and EBESCO databases were systematically searched. The search covered 6 years (January 2010 to June 2016) and the following search terms were included: music, music education, music instruction, music lesson, music training, development, child*, student, pupil. The key words were combined in various ways using Boolean terms AND and OR. Second, reference lists of the identified relevant systematic reviews and key articles (referenced by more than 1 paper) were examined in order to identify additional studies. The last route included a manual search of the tables of contents of relevant journals: International Journal of Music Education and British Journal of Music Education. A flowchart describing these processes is reported in Figure 1.

\section{Inclusion and Exclusion Criteria}

Identified studies were considered eligible for inclusion if they met the following a priori defined criteria. The studies had to (a) involve training, teaching, or providing intervention using music; (b) utilize outcome measures targeting child's development; (c) focus on the (pre)school-aged children up to 13 years without physical disabilities; 
(d) be published in a peer reviewed journal between January 2010 and June 2016; (e) be written in English. We excluded studies that (a) examined use of music psychotherapy interventions; (b) focused only on imaging techniques, (c) had musical outcomes only; (d) were not based on empirical data: qualitative reviews, commentaries, case studies or studies without an accurate methodological description.

\section{Screening and Study Selection}

Upon removal of the duplicates, the literature search yielded 1,092 results. All identified studies were subjected to multilevel screening, executed independently by two co-authors (ED and EVS). First, the titles and abstracts of identified studies were screened. At this stage, the titles and abstracts that did not

meet at least one inclusion criteria (non-English language, commentaries) were omitted. Based on this first screening, 126 potentially relevant articles were obtained as full texts. Next, these articles were further reviewed by ED and EVS independently to determine whether or not they met the stated inclusion

criteria. All exclusion decisions were documented. Each reviewer made a selection list, which were then compared. In cases of disagreement, the articles in question were discussed by all co-authors and a consensus decision was made. Our final selection included 46 articles. 


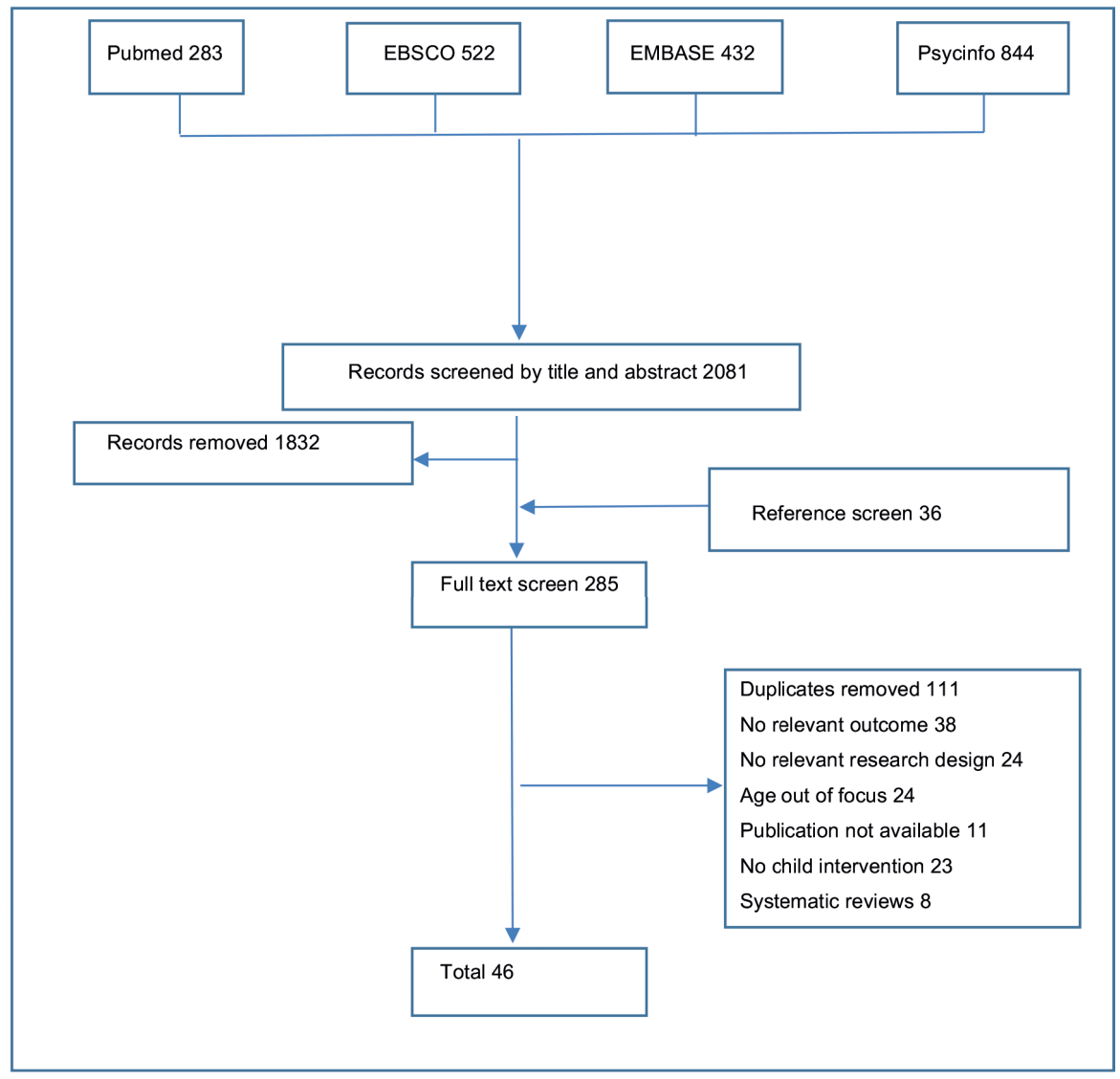

Figure 1 Flow diagram of article identification and inclusion

\section{Data Analysis}

Studies that met at least one inclusion criteria, but did not meet any of the exclusion criteria, have been reported according to a list of five variables in order to extract data in a comparable way. The methodological quality of the studies was assessed using the guidelines of the Dutch Institute for Health Care Improvement (CBO). The following elements were evaluated: randomization, allocation concealment, baseline comparability, blinding of participants or providers, blinding of outcome assessors, reporting of attrition rate, the use of intent-to-treat analyses and the use of validated tools. The level of evidence of each study was determined according to the guidelines of Melnyk \& Fineout-Overholt (2005). 


\section{Results}

The main results of selected studies are reported in Table 1. All studies involved participants of 4-13 years-old, but some were not limited to this range: two studies chose a broad age range of 6-25 years [35] and 6-59 years [32]. Sample sizes varied between 10 [1] and 352 [35]. In general, studies employed both genders. One study [40] and one sub-experiment of a study [42] included males only. Although the type of design was not explicitly mentioned in all studies, most studies implemented $a(n)$ (quasi-) experimental, longitudinal, or correlational design. Only three of the 46 studies used a randomized control trial (RCT) [21] [29] [17]. The reviewed articles have spawned a broad range of approaches to and considerable heterogeneity in music interventions. In general, music interventions consisted either of structured musical instruction/activities, i.e., use of instruments, singing, moving, listening, improvising, music notation, rhythm training, composing music, instrumental classes, or private instrumental training. Only in several studies, the music intervention was especially designed for the acquisition of specific non-musical skills [10] [11]. Length of the intervention varied across studies, ranging from seven and a half minutes [31] to 11 semesters [43]. Music interventions were mostly provided two or three times per week. In three studies, interventions were delivered on a daily basis [15] [16] [25]. All but two studies [32] [40] used live music as opposed to recorded music. Four studies used a specific pedagogical approach for music instruction: the Orff method, which refers to a way of teaching children about music that engages their mind and body through a mixture of singing, dancing, acting, and the use of percussion instruments or the Kodaly method, in which children are first introduced to concepts of music through experiences such as singing, listening or movement. Only after the child becomes familiar with the concept of music do they learn how to compose it [8] [15] [28] [45]. Interventions were either performed in (small) groups or individual (in case of instrumental training). The authors conducted studies either in the school/ classroom environment, where music interventions would be regularly conducted; or used locations outside school i.e., music schools or specific center for music teaching. Information about the person who delivered the music intervention was mentioned in 30 studies. In most studies a professionally trained music teacher was employed. In two other studies, the intervention was delivered by parents/teachers [4] who received training or by trained research assistants [11]. In four studies, the intervention was either computer-based [16] [25] or delivered via CD/radio [32] [40]. The reviewed articles used varied outcome measures affected by music interventions. Outcome 
measures can be grouped in the following categories: motor skill development, social and emotional development, language, cognitive development, academic performance and other, non-musical, related skills.

\section{Motor Skill Development}

We identified no studies that focused particularly on the association between music training and gross motor skill development. Two studies explored, among others, the beneficial impact of music activity on specific motor skills. Using a nonrandomized design, Brodsky \& Sulkin (2011) [1] (which presented results of three experiments) focused on hand-clapping songs. In the first experiment, the association of performance quality of handclapping songs with academic achievement was evaluated among a class of 18 children (mean age 7 years). Two handclapping songs were taught by rote via live demonstration by the second author during a 3-week period and both performance quality and achievement of all 18 children were assessed. Results indicated that children who were more skilful in performing handclapping songs, were also more efficient learners. In a second experiment, the authors measured bimanual rhythmic patting and aural diction in 10 children aged 8-8.5 years, five children who self-reported engagement in handclapping songs activity, and five children from the same classroom who self-reported not to engage in handclapping songs were recruited. Self-reports were confirmed by the second author through observations. The authors found that children who spontaneously engaged in hand clapping songs had an advantage in aural diction and accuracy performance of eye-hand motor sequences. The third experiment took place over 8 weeks. Twenty-four children received classroom handclapping intervention (HCST) while another 27 received the music appreciation guided listening curriculum (MAGL). Children who received HCST were more effective in developing bimanual coupling, writing proficiencies and handwriting compared to children who received MAGL (Brodsky \& Sulkin, 2011 [1]). Janzen et al. (2014) [2] investigated whether formal music training enhances precision in discrete and continuous movements. The study included 32 children enrolled in music classes who had at least 2 h of weekly musical activities. Twenty-five children who were not involved in any musical activity were also included. All were 10-14 years-old. Results showed that musically trained children had a significantly more accurate performance in the discrete movement task compared to controls. Findings suggest performance was positively associated with the number 
of years of formal music training. Musically trained children also tended to be more precise in the continuous movement task (Janzen et al., 2014). Although reporting positive results, a limitation of abovementioned, quasi-experimental studies was the lack of randomization. In a sub-experiment of one study only (sub experiment 3) [1], participants were matched socioeconomically and an active control group was included. In the second study of another sub-experiment, performance of the music group was compared to control groups who were not involved in music training [2] or who did not receive any additional activity (sub experiment 2) [1]. Therefore, caution should be used making inferences about the observed effects of the music interventions on specific motor skills. 


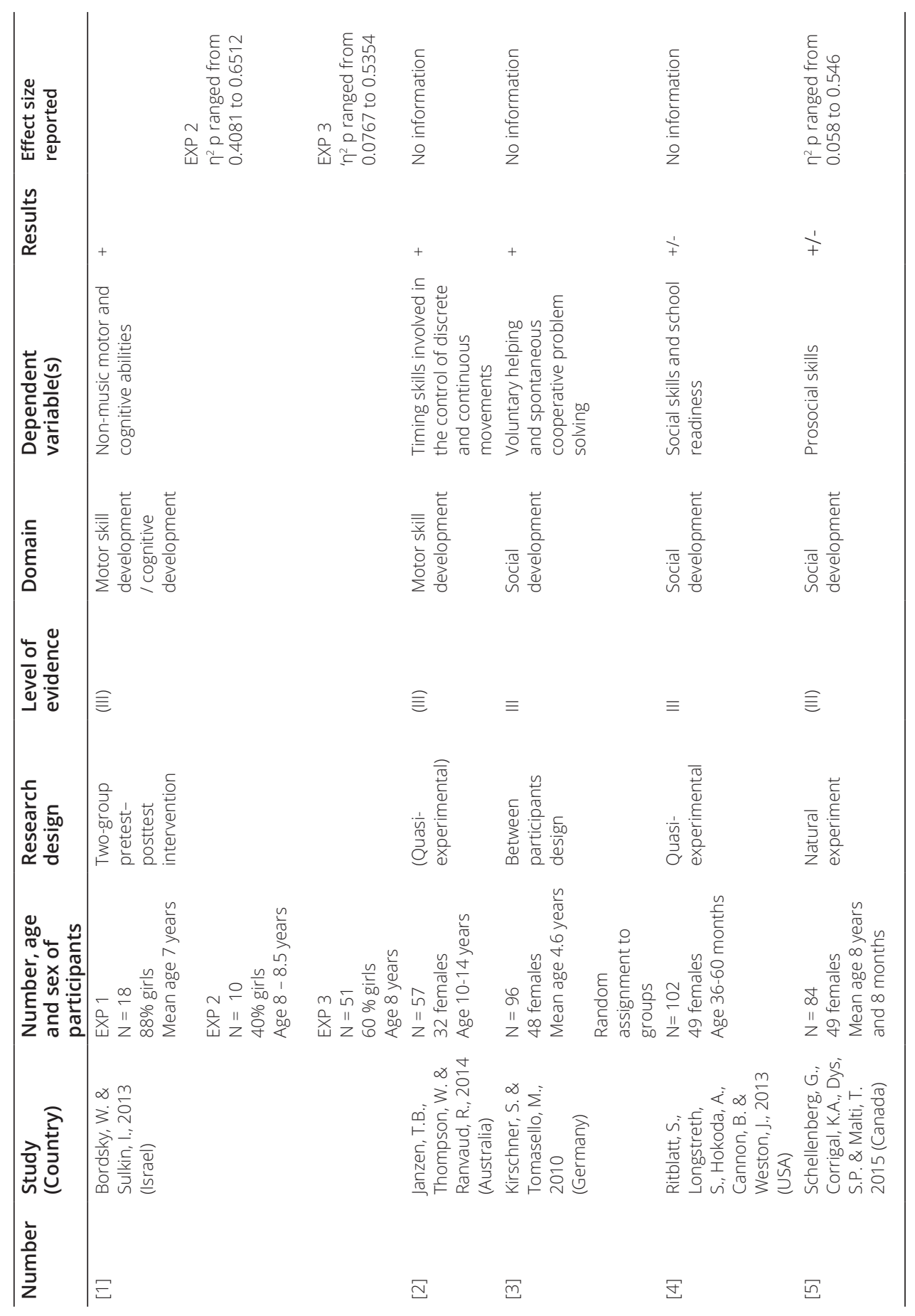




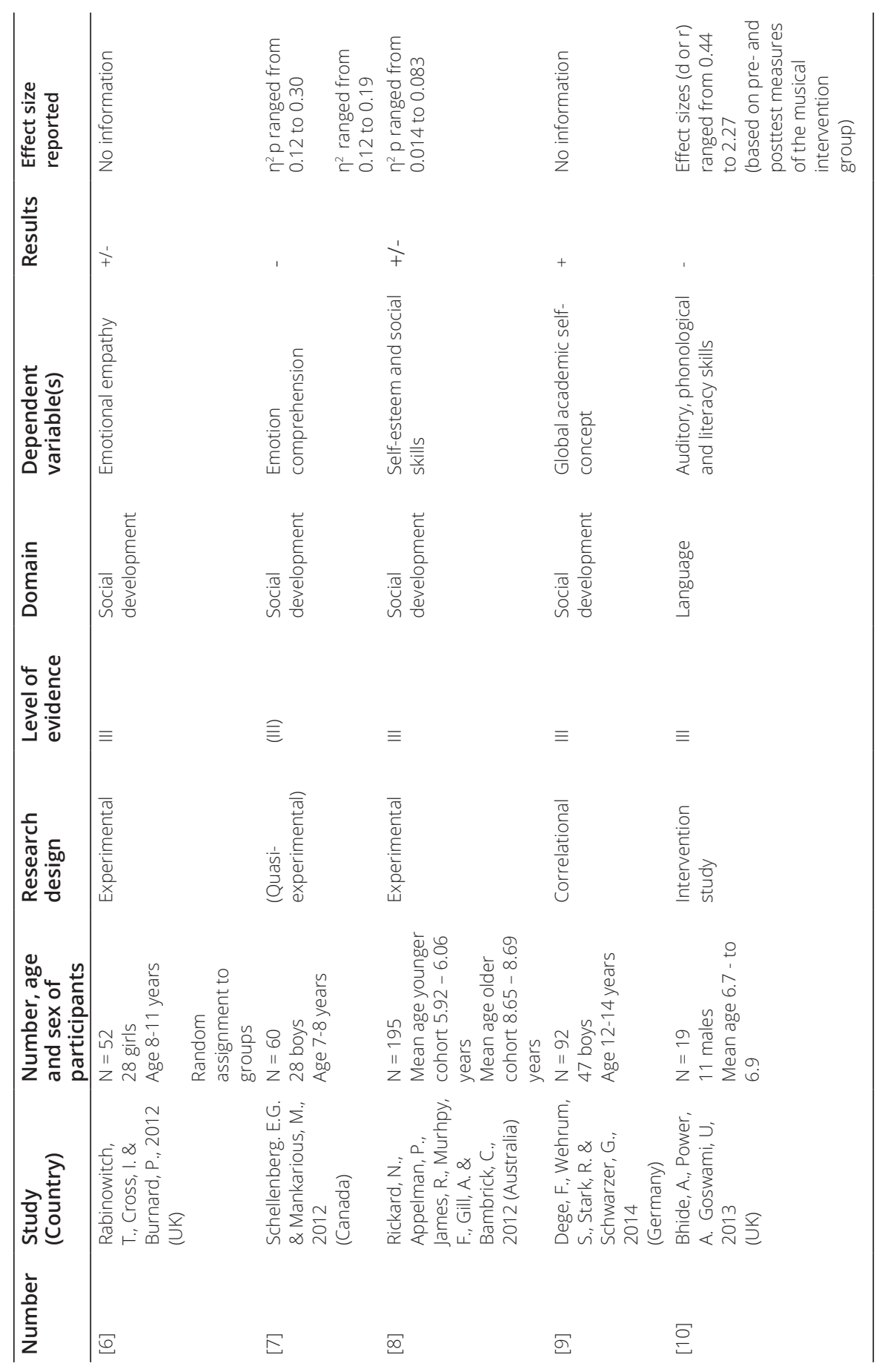




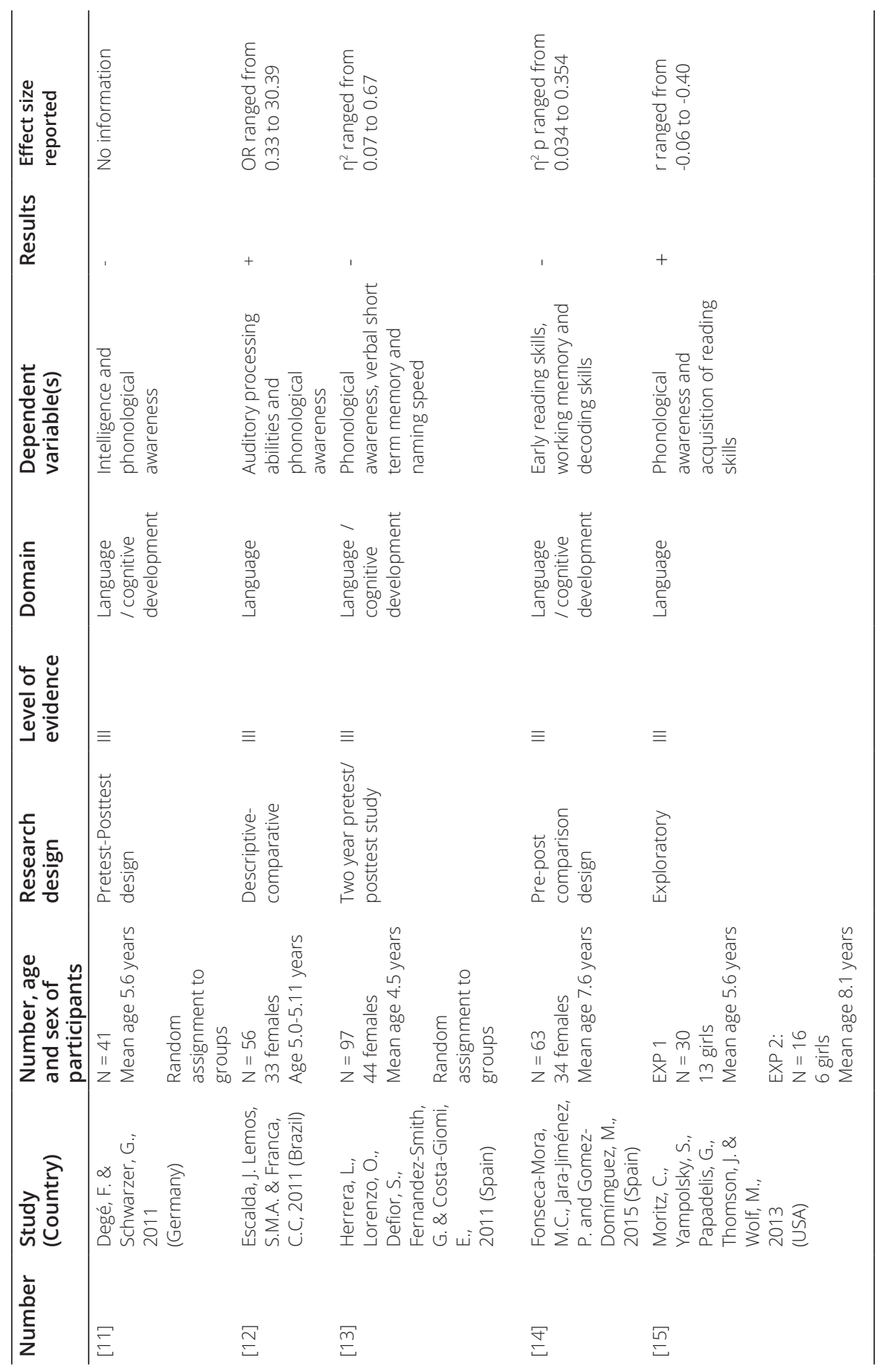




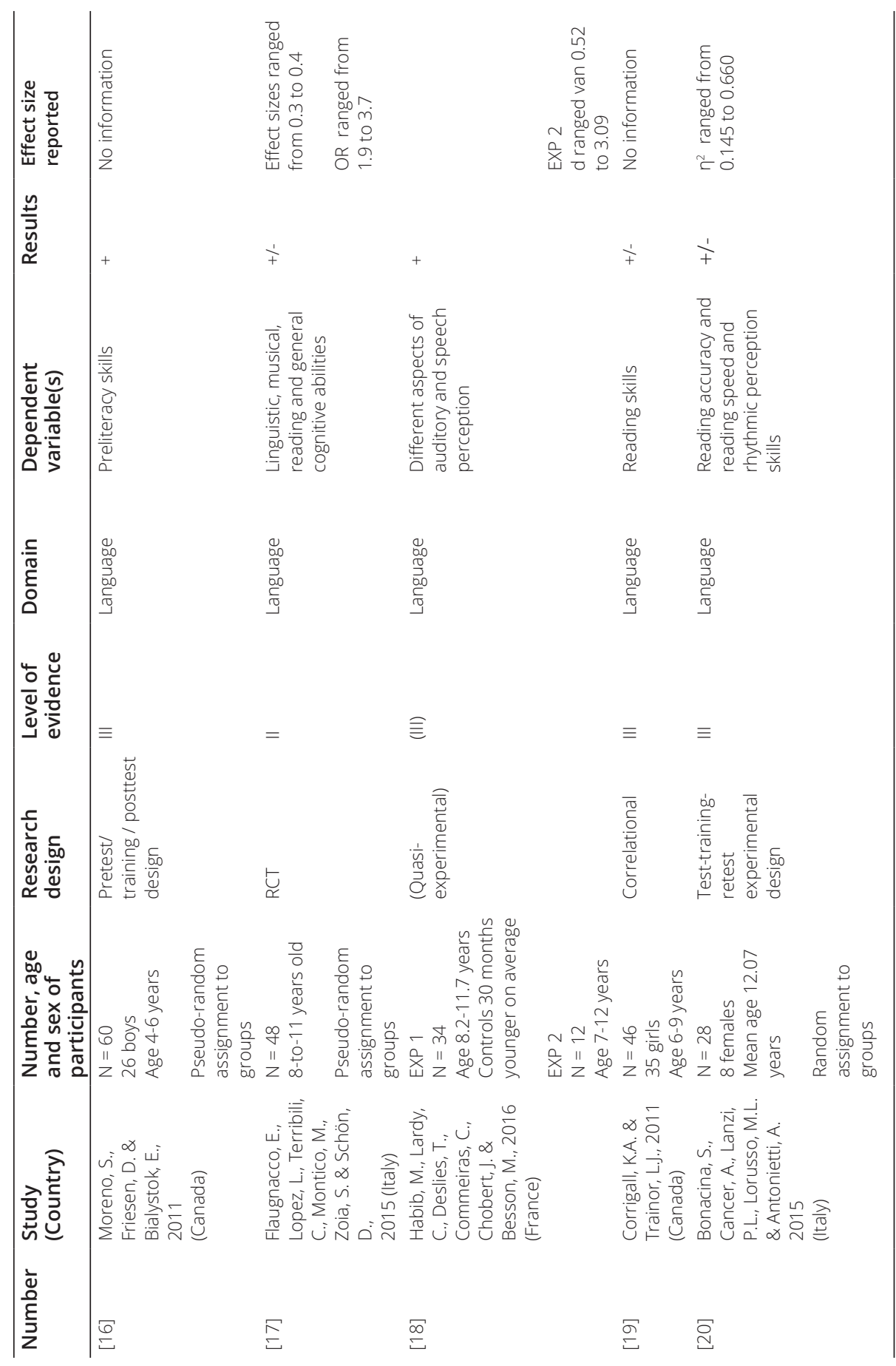




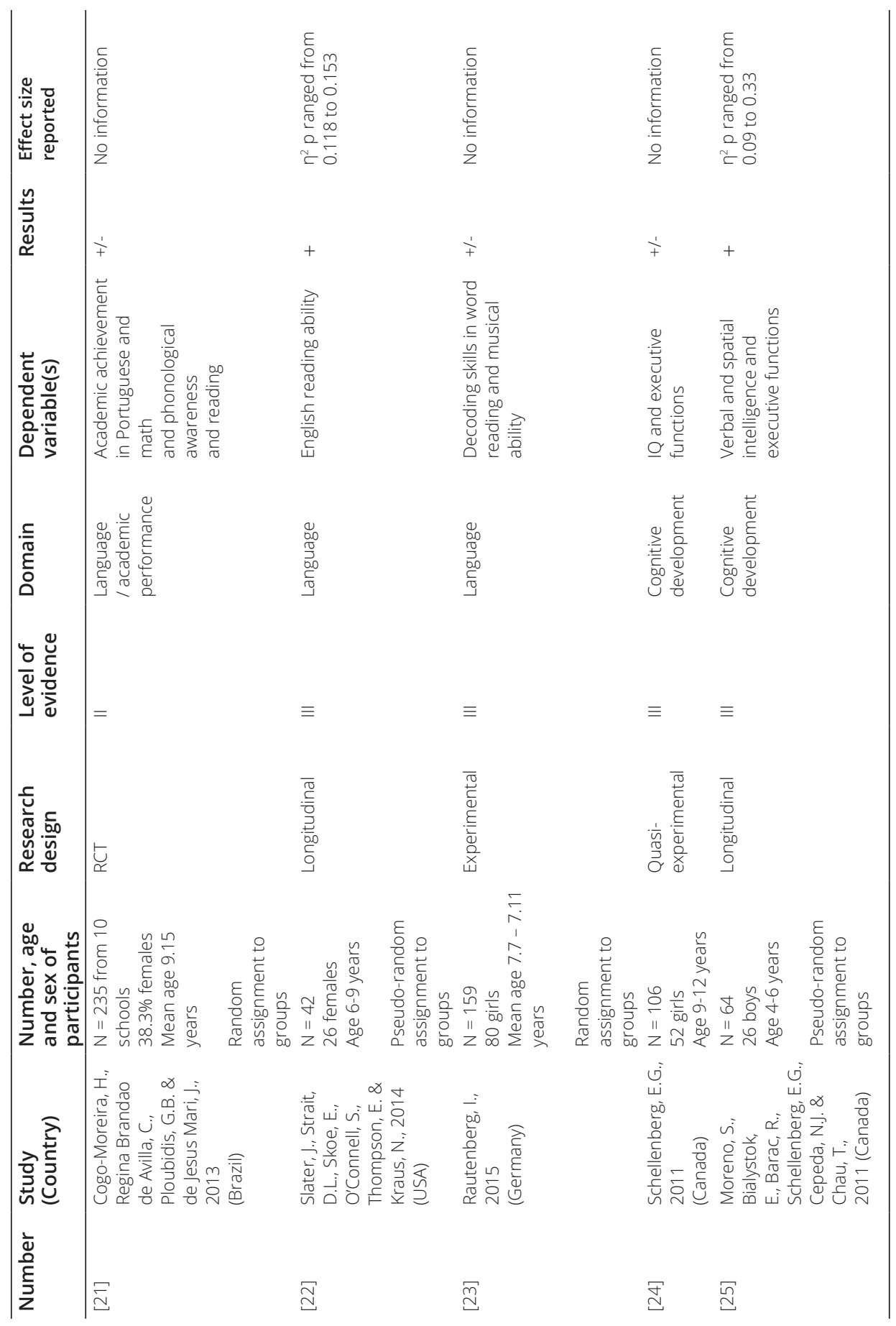




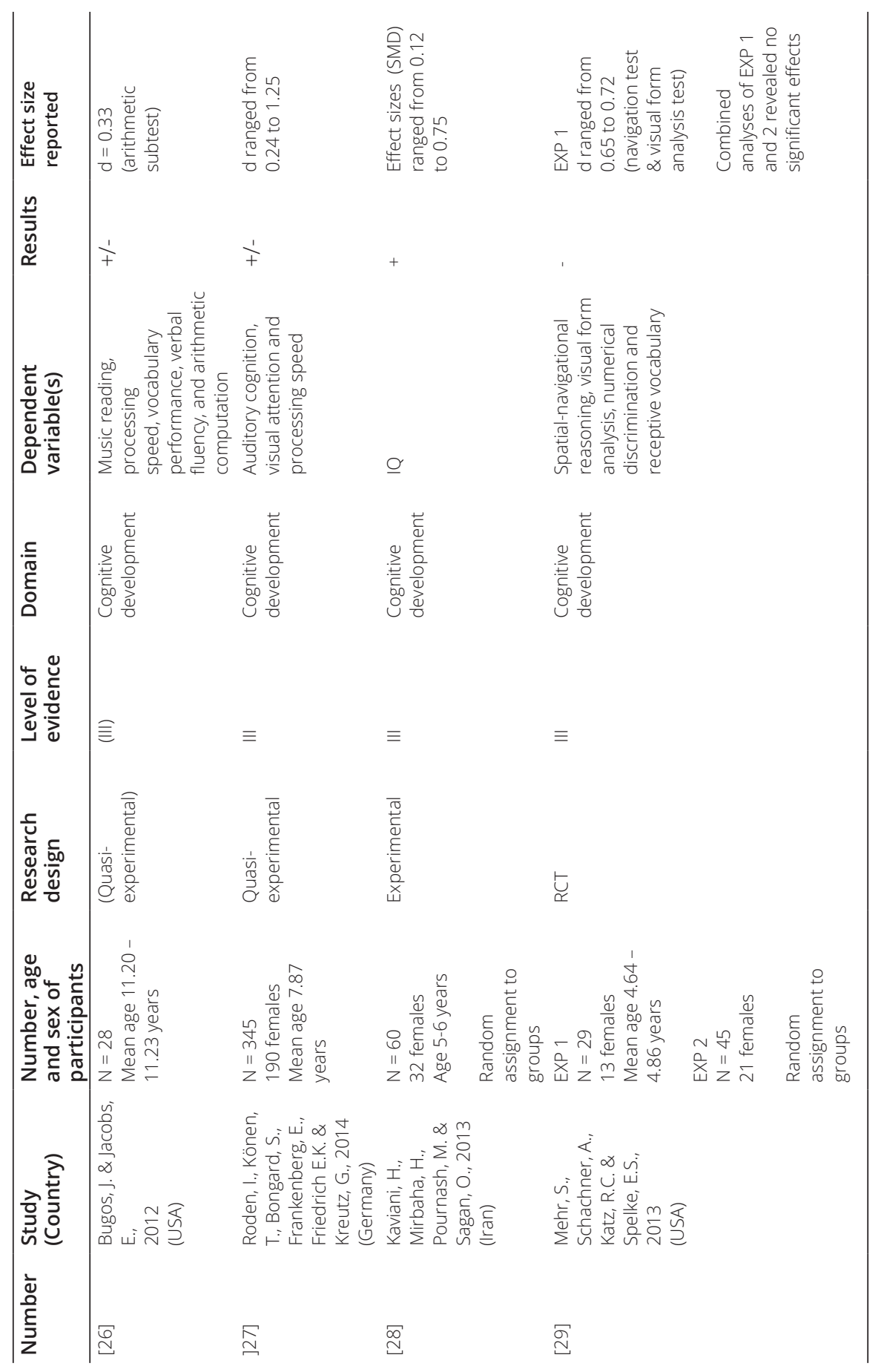




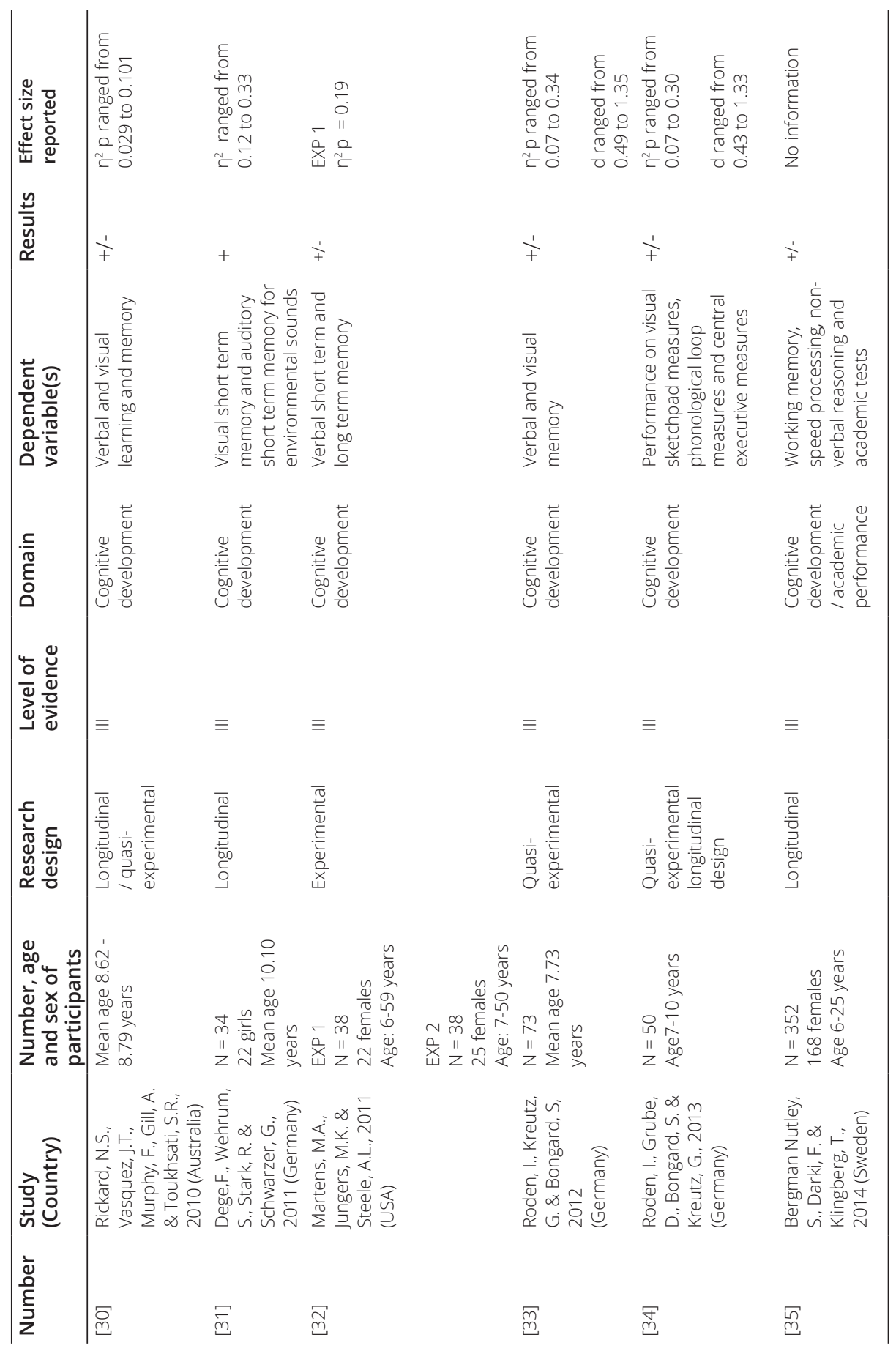




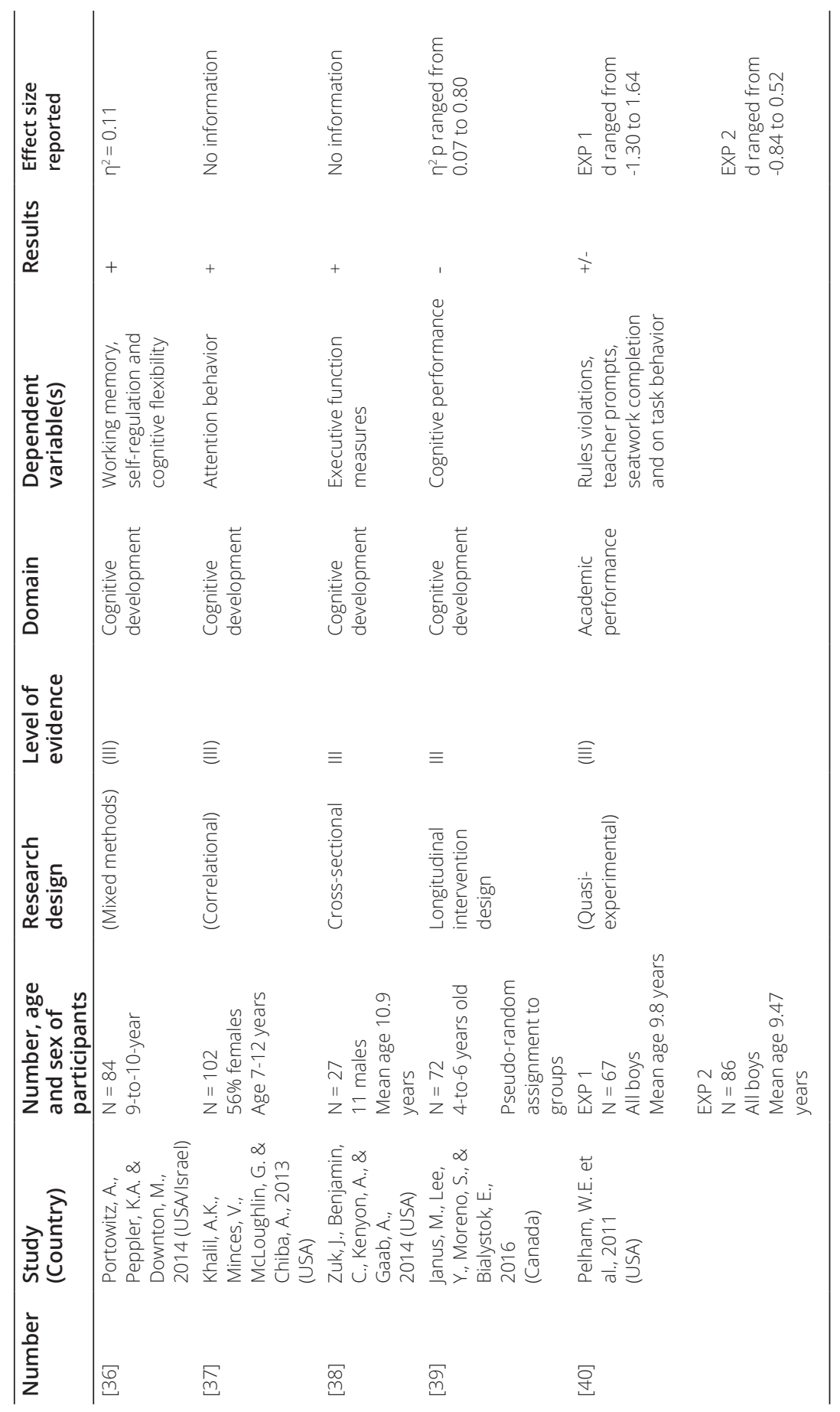




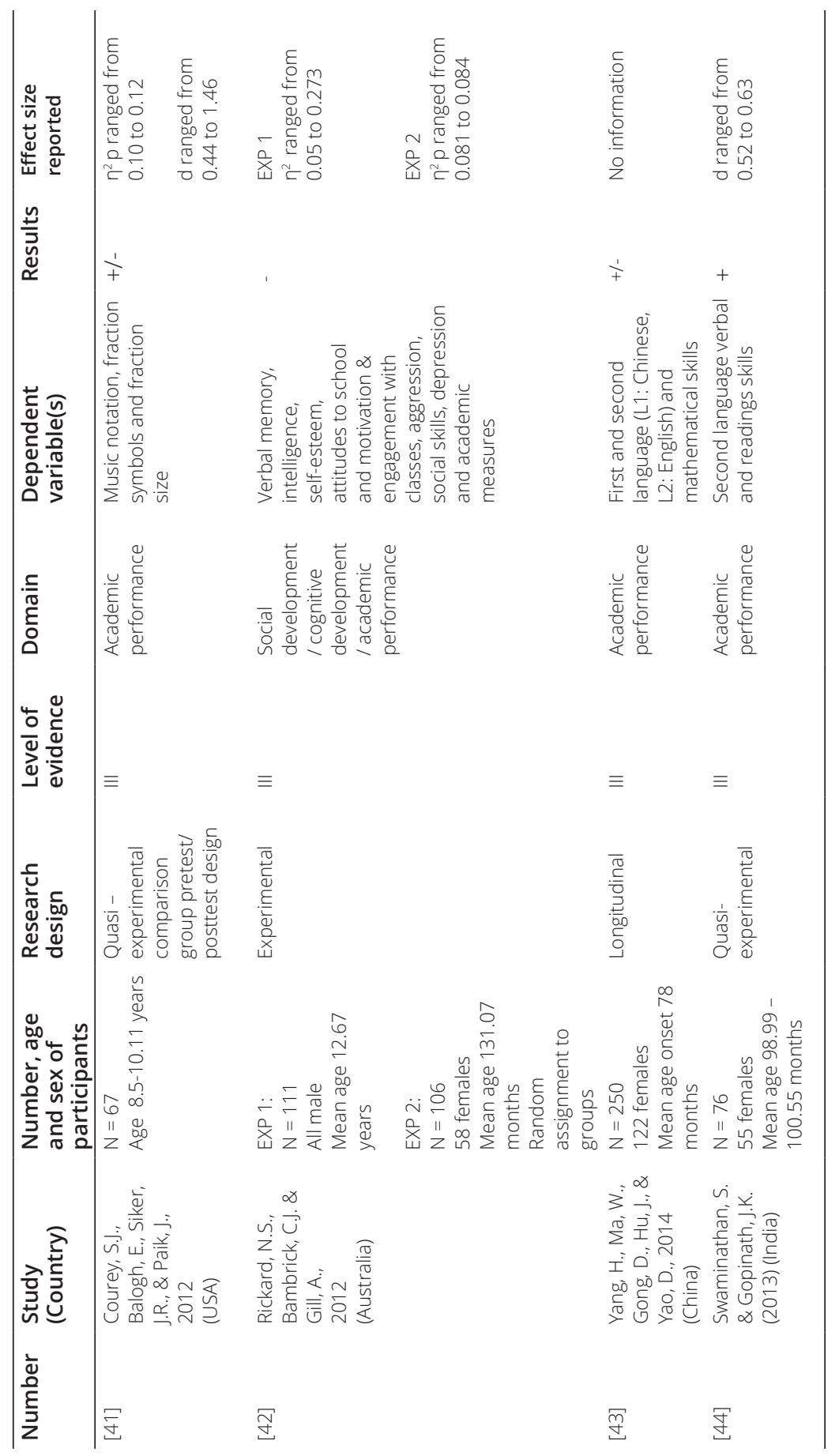




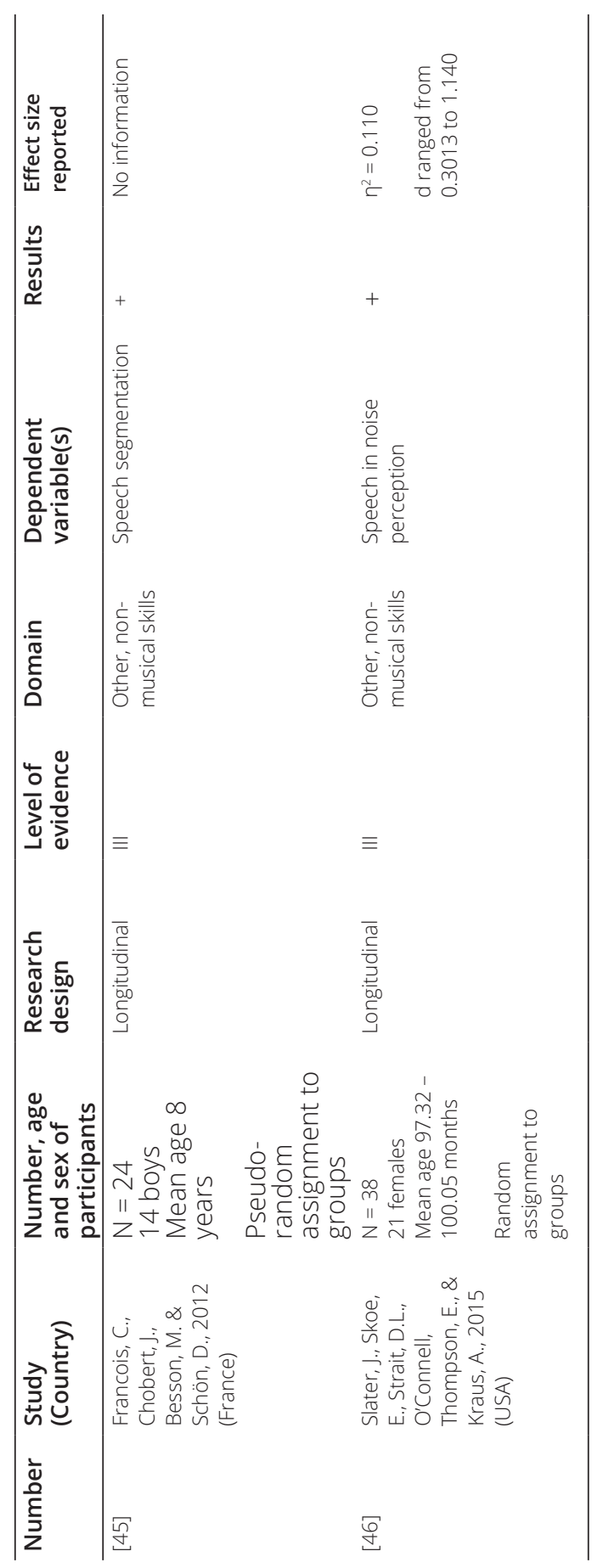

2 


\section{Social and Emotional Development}

\section{Social Skills}

Four studies reported mixed evidence of the influence of music interventions on social skills. Using a quasi-experimental design, Ritblatt et al. (2013) [4] found that 55 children, aged 3-5, who received a music intervention program focused on socioemotional skills, demonstrated a positive change in these skills compared to a wait-list control group $(n=47)$ who did not receive the music intervention. These changes occurred over the course of an 8-month period. It's important to note that these effects were reported by teachers and not parents. Schellenberg et al. (2015) [5] investigated whether social benefits were accrued from an existing group music training program that was designed with music pedagogy as its focus in 84 8-9 yearold children. Results showed that children in the music group ( $n=38)$, who

attended schools that incorporated an enhanced group music program into the curriculum, had larger increases in sympathy and prosocial behaviour compared to children in the control group ( $n=46$ ), who attended schools without the enhanced music program, but this effect was limited to children who had

poor prosocial skills before the lessons began. Evidence from a between-participants study of the effects of joint music making in 48 pairs of 4 year-old children [3] who were randomly assigned either to the music condition (i.e., episode of interactive play with joint music making) or the non-music condition (i.e., episode of interactive play without music), demonstrated an increase in willingness to help one another and to cooperate on a problem solving task in children in the music condition compared to non-music condition (Kirschner \& Tomasello, 2010) [3]. However, in an experimental study, Rickard et al. (2013) [8] assigned 195 5-8 year-old children to either a music education ( $n=122$ ) or a control group ( $n=73$ ) based on the school they were attending. Children receiving a music education received age-specific, specialized music programs on top of the pre-existing, general school music program, while children in the control group did not receive these specialized music programs but continued with their regular school music program. The authors found no benefits of the specialized music program on children's social skills compared to children in the control group. In sum, three studies [3] [4] [5] reported partially positive results, whereas one study [8] reported no effects. One study reporting a beneficial impact of music [3] is of high quality i.c. incorporating random assignment to conditions, 
blinding the outcome assessors and incorporating an active, matched control program without music. The intervention lasted, however, for $20 \mathrm{~min}$. The partially positive findings of Ritblatt et al. (2013) [4] and Schellenberg et al. (2015) [5] should be interpreted with caution due to the design used [5], the lack of randomization, the fact the sample may not be representative of the target population (i.e. higher SES and higher educational level) [4] and teacher/parent expectations which may have influenced the results [4]. In the

experimental study [8] of Rickard et al. (2012) [8], reporting no effects of a specialized music program on top of the general school music program, randomization was absent. However, the relatively large sample size, the duration of the study and the inclusion of an active control group are strengths of this study. Results of above mentioned studies are mixed and demonstrate the need for further research.

\section{Emotional Development}

Two studies addressed the influence of music on emotional development and reported mixed results. A study of Schellenberg \& Mankarious (2012) [7] assessed 60 children, ranging from 7 to 8 years-old, on a test of emotion comprehension (TEC). The musically trained group included 30 children who had at least 8 months of formal music lessons taken outside the school, whereas the untrained group consisted of 30 children who had no music training outside the school. Musically trained children demonstrated significantly higher TEC scores than the ones without music training. The effect remained even after accounting for demographic variables. However, the link appeared to be a consequence of high level cognitive functioning of the musically trained group. No group differences were present when IQ scores were accounted for. Using an experimental study, Rabinowitch et al. (2013) [6] tracked 52 children aged 8-11 after they were randomly assigned to either a musical group interaction program ( $n=23)$, a games group ( $n=8)$, receiving a similar program without the use of music or a control group ( $n=21$ ), not receiving any special activity. Children in the music group showed an increase in empathy scores on two out of three measures compared to children in the games group and children in the control group. While both studies reported positive results, the findings of the study of Schellenberg \& Mankarious (2012) [7] turned out to be a related to the level of cognitive functioning of participants in the music group. The experimental study of Rabinowitch et al. (2013) [6] permits, at least to some extent, for causal inference. The authors used randomization to allocate participants to conditions, 
thereby reducing the risk of bias from confounding. The small sample size and the fact that the active and the passive control group were merged into one control group before comparison with the music group, should, however, be taken into consideration. Based on findings from both studies, no definitive conclusions can be drawn yet and more research is needed in this area to achieve conclusive results.

\section{Academic Self-Concept, Psychosocial Wellbeing, and Self-Esteem}

Three studies reported mixed effects of music on academic self-concept, which refers to the cognitive representation and appraisal of one's own abilities in academic performance (Degé et al., 2014), psychosocial wellbeing and self-esteem, which describes one's overall sense of self-worth. In a correlational study, Degé et al. (2014) [9] revealed that duration of music lessons was positively associated with academic self-concept in 92 12-14 year-old children, even after controlling for demographic variables and IQ. In a 3-year experimental study, Rickard et al. (2013) [8] showed that increase in school-based music lessons prevented a decline in global self-esteem measures experienced by the control group in both the younger and older cohorts across the first year of the study. However, effect sizes were generally modest in the second year. In another study, Rickard et al. (2012)

[42] investigated the effect of increasing existing music education (study 1) and the effect of introducing a novel high-quality music education program(study two) on various psychosocial measures in 111 10-13 year-old children (all males). One hundred eleven 10-13 year-old children in study one were pseudo-randomly assigned to additional music classes ( $n=47)$, art classes $(n=27)$, or drama classes $(n=37)$. One hundred six children in study two (mean age 131.07 months) were randomly allocated to a music group ( $n=38$ ), a drama group ( $n=37$ ) or control group, receiving no $\operatorname{program}(n=31)$. No significant effects were found. Degé et al. (2014) [9], using a correlational design, was the only one reporting positive results. However, these results do not allow for any conclusions to be drawn about causality. Two experimental studies of Rickard et al. (2012) [8] [42] found modest effects and no effects, respectively music interventions on top of the pre-existing school music education. The (relatively) large sample sizes [8] [42] and the duration of one the studies [8] can be considered as strengths. Both studies, did not, however, randomize participants to the intervention or control groups. In one of the two experimental studies [42], active control groups were included, who continued their regular school music 
program. The other study [8] included both passive and active control groups, which better allowed for comparison of the increased music education. In summary, although one study reported positive correlations, two studies suggest little or no beneficial effect. Further research is needed to clarify whether music can positively impact self-concept, self-esteem, and psychosocial wellbeing.

\section{Language}

Studies that link music intervention to language acquisition can be clustered into two groups: (1) focus on phonological awareness and auditory processing and (2) reading.

\section{Phonological Awareness and Auditory Processing}

Several studies assessed the influence of music on auditory and phonological skills with mixed findings. Some suggest that musical activities have a beneficial effect on these skills. Using a descriptive-comparative design, Escalda et al. (2011) [12] examined the relationship between musical experience, auditory processing abilities and phonological awareness skills of 56 five year-old children. Results showed that 26 children, with musical experience, performed significantly better on auditory processing and phonological awareness than 30 children without musical experience. In an exploratory study, Moritz et al. (2013) [15] investigated whether musical activity could enhance the acquisition of reading skill, potentially before formal reading instructions began in 30 children (mean age 5.6 years). Children

in the music group ( $n=15$ ) received daily 45 min music lessons whereas children in the control group $(n=15)$ received weekly 35-min music lessons. Correlational results showed that rhythm ability was related to phonological segmentation skills at the beginning of kindergarten and that end-of-year phonological awareness skills of children who received daily music lessons were better than skills of children in the control group who received music lessons once a week. Using a pragmatic RCT, Cogo-Moreira et al. (2013) [21] included 235 participants with reading problems, aged 8-10 years, in 10 schools, to compare the effectiveness of music education for the improvement of among other, reading skills. Five schools were randomly chosen to incorporate music classes $(n=114)$ and five schools, who

were not encouraged to offer musical activities, served as controls ( $n=121$ ). There was no improvement in phonological awareness when comparing the two groups. 
Flaugnacco et al. (2015) [17], also using an RCT, pseudo-randomly assigned 8-11 yearold dyslexic children to a music group $(n=24)$ or a painting group $(n=24)$. Both groups also received conventional rehabilitation program. After 7 months of training, the music group outperformed the painting group in tasks assessing rhythmic abilities and phonological awareness. Using a pretest/training/posttest design, Moreno et al. (2011b) [16] focused on the effects of an intensive computerized training in music or visual arts on pre-literacy skills in 60 4-6 year-old children, who were pseudo-randomly assigned to the music or visual arts condition. They reported comparable improvements in both groups in rhyme awareness and in ability to map unfamiliar symbols to known words. However, when the two groups were statistically equated at pretest, the magnitude of improvement was found to be larger in the music group. Herrera et al. (2011) [13] on the other hand, used a 2 year pretest-posttest study in which 97 children (mean age 4.5 years) at two preschools were allocated following stratified randomization procedures into a group that received phonological training with music $(n=32)$, a group that received phonological training with no music $(n=34)$ and a control group who did not receive any specialized training $(n=31)$. Phonological training was

effective regardless of whether it included music and whether the children were foreign Spanish speakers or native speakers. Both experimental treatment groups outperformed the control group in the posttests on phonological awareness tasks and speed in naming objects. However, the phonological training with music group outperformed the phonological training without music group on phonological awareness of ending sounds. In general, the foreign Spanish speakers were significantly slower in the naming task than their Spanish counterparts, those who had participated in the training with musical activities outperformed their peers in the control group by the end of the treatment. Bhide et al. (2013) [10] compared the effects of a musical intervention for poor readers $(n=10)$ with a software intervention of known beneficial effects based on rhyme training and phoneme-grapheme learning $(n=9)$ in 6-7 year old children, all of them identified by their class teachers as struggling readers. The authors found that both interventions were equally effective for literacy acquisition and phonological skills. Habib et al. (2016) [18] examined the effectiveness of a specially-designed Cognitivo-musical training (CMT) in two

studies. In study one, 12 children with a diagnosis of severe dyslexia (mean age 10.7 years) received daily 6 hours of CMT on 3 consecutive days while 22 readingage matched normal-reading children (30 months younger on average) served as 
controls, receiving no CMT. The authors found that dyslexic children were impaired in the identification test of categorical perception, but their performance reached the level of control children after 3 days of CMT. Significant improvement in performance of dyslexic children was also noticed in the syllabic lengthening task. In study two, 12 dyslexic children, grouped according to the severity of their problems received CMT training sessions at school. The 3-hour weekly sessions were provided over a period of 6 weeks. Results showed a positive influence of the CMT program on categorical perception and the temporal aspects of speech processing. Also, additional improvements in auditory attention, phonological awareness (syllable fusion) were found. Fonseca-Mora et al. (2015) [14], using a pre-post comparison design, tested the efficacy of a phonological training program aimed at improving early reading skills in 7-8 year-old Spanish children learning English as a foreign language in three groups: an experimental group with phonological non-musical intervention ( $\mathrm{n}=$ $22)$, an experimental group with musical intervention $(n=18)$ and a control group receiving the traditional teaching program $(n=23)$. The results clearly pointed to the beneficial effects of the phonological teaching approach, but the further impact of the music support was not demonstrated. In a longitudinal, experimental study, Degé \& Schwarzer (2011) [11] investigated the effect of a music program on phonological awareness in preschoolers. Forty-one children (mean age 5.6 years) were randomly assigned to a music program $(n=13)$, a phonological skills program $(n=13)$, or a sport group $(n=14)$. Results indicated that 26 children who followed either the music program or the phonological program significantly improved in phonological awareness of large phonological units (words) compared to the sport group who received no intervention. All three groups showed similar development in phonological awareness of small phonological units. Of the two RCTs reviewed, one found beneficial effects of a music intervention on phonological awareness [17] while the other found no effects [21]. Two experimental studies [11] [13], using (stratified) randomization and including two active control groups [11] and an active and passive control group [13], respectively, reported no beneficial effects of

music. Of the four studies that used a quasi-experimental design without randomization, two studies, including an active [10] or both an active and passive control group [14], also found no benefits of music interventions One out of these four studies, reporting positive results, used pseudo-random allocation, included an active control group and blinded outcome assessors [16]. Another study, also describing positive results, matched participants, but did include a passive control group only 
[18]. Positive results were also reported by two correlational studies [12] [15]. However, these results do not allow for any conclusions to be drawn about causality. Although findings suggest music can positively affect phonological awareness and auditory processing in some situations, clear conclusions cannot be drawn.

\section{Reading}

Eight studies addressed the association between music-related activities and a range of reading skills with inconsistent findings. The results of the study of Cogo-Moreira et al. (2013) [21] indicated no improvement in word accuracy, in-text accuracy and non-word accuracy of children in the music intervention schools compared to the children in control ones. In contrast, the RCT results of Flaugnacco et al. (2015) [17] showed better performance of the music group on reading skills in comparison to the control group. Using an experimental design, Bonacina et al. (2015) [20] randomly assigned 11-14 year-old children to a computer-assisted, rhythmic reading training (RRT) $(n=14)$ or a control group $(n=14)$, for which no specific activity addressed to improve reading skills was carried out. Results indicated that RRT had a positive effect on both reading speed and accuracy. The effect of RRT seemed to be specifically on reading skills, as no difference in rhythm perception between the two groups was found. Moritz et al. (2013) [15] found that kindergarteners' rhythm ability was significantly correlated to their phonological awareness and basic word identification skills in second grade. Using a longitudinal design, Slater et al. (2014) [22] compared reading ability of 42 low-income, Spanish-English bilingual children aged 6-to-9, pseudo-randomly assigned to a group music instruction program outside school or a waiting list control group. Twenty-three children in the music group maintained their age-normed performance on the composite reading measure after 1 year, whereas the performance of 19 children in the matched control group deteriorated over the same period of time, consistent with expected declines in this population. Rautenberg (2013) [23], in an experimental study, measured the correlations between musical skills and decoding skills and the effects of musical training on word-level reading abilities. One hundred fifty-nine seven year-old children were randomly allocated to a special music training program $(n=33)$, a visual arts training program $(n=41)$, or no training program for the period of the study $(n=85)$. Results showed the special music training had a significant effect on reading accuracy in word reading. Additionally, positive correlations were found between rhythmical ability and decoding skills. Tonal skills were not correlated with reading skills. In a correlational study of Corrigall \& 
Trainor (2011) [19], it was shown that duration of music training (i.e., the number of years of training on their primary instrument, plus the number of years of training on any additional instruments) was associated with reading comprehension, but not with word decoding among 46 6-9 year-olds. The findings are in contrast to a longitudinal study from Bergman Nutley et al. (2014) [35] which revealed that practising a musical instrument was not associated with reading comprehension. Of the eight studies measuring the effects on reading, two studies used an RCT design with pseudo randomization [17] [21] and blinded outcome assessors [17]. Their findings are contradictory; Flaugnacco et al. (2015) [17] found a positive

influence of music, whereas the results of Cogo-Moreira et al. (2013) [21] indicated no effect. Results of two studies that used an experimental design with randomization [20] [23] illustrated potential benefits of a music training program. Of these two studies, one included a passive control group, offering no music training program [20] while the other included both a passive and active control group [23], allowing for a more comprehensive comparison. The results of the longitudinal study of Slater et al. (2015) [46] also point to beneficial effects. However, an active control group could not be included. (Partially) positive correlations were shown by two studies [15] [19]. However, correlational studies do not allow for causal inferences. In another longitudinal study [35], participants were compared to themselves. Attrition rate and practice effects might, however, have influenced the results. As results of above-mentioned studies are both positive and negative, findings in this area are inconclusive.

\section{Cognitive Development}

In this review, studies focusing on the effects of music on children's cognitive abilities were subdivided into three categories, reflecting different aspects of cognitive development: (1) intelligence, (2) memory, and (3) attention and other executive function skills.

\section{Intelligence}

Several studies have explored the effects of music intervention on intelligence. Results from these studies suggest little or no beneficial effects. In an experimental design, Kaviani et al. (2014) [28] randomly allocated 60 5-6 year-old children to two groups, the experimental group receiving Orff music lessons and the other (matched for age-, sex-, and mother's educational level) receiving no lessons The authors demonstrated 
that after participating in the Orff music program for 3 months, children had significantly higher scores on the visual abstract reasoning, verbal reasoning and short term memory subscales of the Stanford_Binet Intelligence Scale compared to children, who did not receive any musical lessons. Schellenberg (2011) [24] and Bergman Nutley et al. (2014) [35] also reported positive

associations between, respectively, music training and IQ and music training and nonverbal reasoning. In a longitudinal study, Moreno et al. (2011a) [25] used two subtests of the WPSI III (vocabulary and block design) to examine the influence of two interactive computerized training programs (music and visual arts) on, among other skills, verbal and spatial intelligence in 64 4-6 year-old children who were pseudo-randomly allocated to one of the two conditions. They found that children who participated in a computerized music training program showed enhanced performance on the measure of vocabulary knowledge. Not in line with above mentioned findings is the study of Mehr et al. (2013) [29]. They conducted an RCT to investigate the effects of parent-child music education on specific cognitive skills

in preschool children. In experiment one, four-year-old children were randomly assigned to a music group ( $n=15)$ or a visual arts group ( $n=14)$. In experiment two, 23 children were randomly allocated to a music group and 22 children to a control group who did not receive music classes. Analyses with a combined music group ( $n=38$ ), the visual arts group and the control group revealed no significant effects on spatialnavigational reasoning, visual form analysis, numerical discrimination, and receptive vocabulary. Rickard et al. (2012) [42] failed to find an effect of increased classroom based music education on various cognitive measures. Bugos \& Jacobs (2012) [26] evaluated the effects of a composition program, Composers in Public Schools (CiPS), on cognitive skills among 28 sixth-graders who were assigned to an experimental group ( $n=15)$, receiving the CiPS program or a control group ( $n=13)$, not participating in any musical courses. Results showed enhanced performance in arithmetic scores of the WISC-IV for the experimental group compared to the control group. No effect was found for vocabulary performance. Due to a relatively large variation in scores, enhancements for digit coding

and symbol search subtests were not significant. Only one out of the seven studies measuring the effects of music on intelligence, employed an RCT design including an active as well as a passive control group [29], which permits causal inferences to be made. No significant effects were found in that particular study. The two experimental 
studies reviewed [28] [42] yielded mixed results. While both used randomization [28] [sub experiment 2, 42], only one study, reporting no effect, included an active control group [42]. The remaining four studies, employed a quasi-experimental (longitudinal) design [24] [25] [26] or longitudinal developmental design [35], showed positive or partially positive effects. However, only one out of these four studies used pseudo-randomized group assignment, blinded outcome assessors and included an active control group. Schellenberg (2011) [24] and Bugos \& Jacobs (2012) [26] both included a passive control group. Neither study matched participants on baseline variables. Despite the large sample size and duration of the study, caution is needed in interpreting findings of Bergman Nutley et al. (2014) [35], due to attrition and the possible influence of practice effects.

\section{Memory}

A number of studies looked specifically at aspects of memory with mixed results. Degé et al. (2011) [31] demonstrated in a non-randomized, longitudinal design that after 2 years of extended music curriculum (ECM) training, short-term visual, and auditory memory scores for 16 9-11 year-old children, attending ECM training, had improved significantly, whereas no such increase was found in 25 children who did not attend ECM training. Roden et al. (2012) [33] conducted a quasi-experimental study where participants were allocated to a music program, a science program or a control group. Results showed that 25 children (mean age 7.73 years), who took part in a school-based music program, outperformed 25 children receiving extended natural science training and 23 children in a control group receiving no additional training, on verbal memory tasks. The authors failed to show a link between type of program and visual memory. Brodsky \& Sulkin (2011) [1] reported positive effects of classroom handclapping intervention (HCST) on verbal memory. Results of a longitudinal study by Rickard et al. (2010) [30] showed significant enhancement of verbal learning and immediate verbal recall scores in 82 children (mean age 8.62 years) after 1 year, but not 2 years after non-random allocation to an increased classroom-based instrumental music training, compared to 68 children (mean age 8.79 years), who did not receive training. In an experimental design, Martens et al. (2011) [32] focused on the effect of musical experience on verbal memory in 38 individuals with Williams syndrome, aged 6-59 years. Participants who had participated in formal music lessons scored significantly better on a verbal long-term memory task when the stimuli were sung than when they were spoken in comparison to those who did not have formal lessons, 
showing no benefit for either sung or spoken condition. Short-term memory did not appear to be affected by musical experience. The five studies reviewed yielded mixed results. One experimental study [32] showed improved performance of participants who had participated in formal music lessons. However, generalizability of findings is low by including only participants with Williams syndrome, making the participants a non-representative sample. The remaining four studies, reporting positive or partially positive results, employed quasi-experimental (longitudinal) designs [1] [30] [31] [33]. However, in none of these four studies, participants were randomized or matched on potentially influencing variables, decreasing validity of findings. Blinded outcome assessors were used in one study

[30]. Two out of the four studies included an active control group [1] or both an active and passive control group [33], allowing for a more detailed comparison. Although studies suggest potential benefits, the methodological limitations do not allow clear conclusions to be drawn about the effect of music and the part(s) of memory of which music can have an effect on.

\section{Attention and Other EF Skills}

The impact of music interventions on attention and several executive function skills was reported in seven studies with mixed evidence. One study of 102 7-12 year-olds Khalil et al. (2013) [37] found that, those, who were able to synchronize to a driving beat (in the context of a music class), were more attentive, showed less ADHD-like behaviours (rated by teachers) and performed better on an attention control task, in comparison to those who were less capable of synchronizing. Positive results have also been shown by Moreno et al. (2011a) [25], who reported enhanced performance on accuracy on a go/no-go task. Using a cross-sectional design, Zuk et al. (2014) [38] assessed (among other participants) 27 children (mean age 10 years) on a range of EF tasks. Fifteen instrumentally trained children, who started training on average at 5 years and had been studying their instruments on average 5.2 years, demonstrated heightened performance on coding, cognitive flexibility and processing speed

tasks in comparison with 12 children without musical training outside the requirements of the general music curriculum in school. In contrast, Roden et al. (2014) [27], using a quasi-experimental design, investigated, among other skills, the effects of music lessons on processing speed abilities and visual attention in 7-8 year-old children over a period of 18 months. In the study, 345 children were assigned to the music 
training group ( $n=192$ ) or the natural science training group ( $n=153)$. Children in the music group showed significant increases in information processing speed from T2 to T3. However, the

level of significance was only associated with a small effect size. Although both groups improved their visual attention scores over time, these increases were stronger from T1 to T2 and T2 to T3 in children with natural science training as compared to children with music training. In a quasi-experimental study,

Schellenberg (2011) [24] found that, with the exception of digit span, music training was independent of performance on phonological fluency, inhibition, problem solving, and planning and mental flexibility and rule switching. Bugos \& Jacobs (2012) [26] found no effect of participation in a 4-month composition program on verbal fluency. Using an intervention design, Janus et al. (2016) [39] pseudo-randomly assigned 57 4-6 year-old children (matched on age and cognitive scores) to a 20-day music training $(n=28)$ or conversational French training program $(n=29)$ to compare the effects on executive control abilities. The one training-specific outcome found was that children in the French group showed broader improvement in visual search than children in the music program. For verbal fluency, grammatical judgement and visual search, all children performed significantly better after training. Several studies suggested music training may improve various aspects of working memory. In one quasi-experimental, longitudinal study (Roden et al., 2014) [34], examined working memory performance in 25 7-10 year-old children who participated in a classroom-based, extended instrumental music training program and 25 children who participated in an extended science training program. Results showed significant gains in two out of three components of working memory performance in children who followed the music program for one-and-a-half-years in comparison to children who took part in the science training group. Positive associations between musical practice and working memory were also reported by Bergman Nutley et al. (2014) [35] and Zuk et al. (2014) [38]. Portowitz et al. (2014) [36] reported a significant enhancement in working memory scores in 62 9-10 year-old children after a 4-month participation in the (computerized) In Harmony program compared to 22 controls who did not participate in this program.

The results of the study of Janus et al. (2016) [39] showed no effect of a music training program on spatial working memory. The seven studies reviewed yielded mixed 
results of the influence of music interventions on attention and other EF skills. Positive correlations were shown by one study [37]. However, correlational studies do not allow for causal inferences. The remaining six studies were quasi-experimental (longitudinal) without randomization [24] [25] [26] [27] [38] [39]. Two of these six studies, reporting positive results, used pseudo random allocation of participants to groups [25] or matched participants on potentially confounding variables [38] but only one included an active control group [25]. Two other studies reported mixed and modest results, respectively [27] [24]. The sample size and the inclusion of an active control group can be considered as strength of one of them [27]. Of the remaining two studies [26] [39], reporting no evidence of beneficial effects of music, only one used blinded outcome assessors, pseudo randomization, and included an active control group [39]. Regarding working memory, there seems to be a hint of a positive influence of music based on the results of five studies [34] [35] [36] [38] [39]. However, studies were quasi-experimental (longitudinal) without randomization [34] [36] [38] [39] or longitudinal developmental [35]. Only three out of the five used pseudo random allocation [39] or matched participants on potentially confounding variables [36] [38]. An active control group was included by two out these five studies [39] [34], reporting no effects and mixed effects, respectively. The three other studies, all reporting positive findings, included a passive control group [36] [38] or compared the participants to themselves [35]. Although part of the evidence points to potential benefits, more research is needed to determine whether music can positively impact these skills.

\section{Academic Performance}

Studies exploring the effect of music on academic performance were subdivide into four categories: (1) school readiness, (2) classroom behaviour and academic skills and (3) language, and (4) mathematics.

\section{School Readiness}

One study focused, among other skills, on preschool children's school-readiness skills. The results of a quasi-experimental study of Ritblatt et al. (2013) [4] showed that participation in a music program had a positive effect on promoting a positive approach to learning. No effect was found for promoting academic skills. Methodological limitations of this study are the lack over control over assignments of 
participants to conditions and the fact the sample may not be representative of the population as whole (i.e. higher SES and higher educational level), creating threats to validity. Information about the blinding of outcome

assessors was not provided. The intervention was provided by trained teachers and parents, whose expectations may have influenced outcomes. Taking the limitations into account and the fact that the findings are based on one study only, accuracy and direction of the results should be interpreted with caution.

\section{Classroom Behaviour and Academic Skills}

There is no evidence that music can affect classroom behaviour and academic skills. Pelhamet al. (2011) [40] followed up 41 boys with ADHD and 26 normal comparison boys, who had never been referred for treatment of behaviour problems (mean age 9 years) to examine the effects of music and video on classroom behaviour and performance. Three distractor conditions (music, video, no-distractor) were randomly introduced for 24 days, varying on a daily basis (8 days in each distractor condition). Neither boys with ADHD or the control group were significantly distracted by music. Within the ADHD group, there were, however, considerable differences in response to the music such that some were adversely affected and others benefited relative to no-distractor. This study included males only, thereby eliminating a potential source of variability. Except for gender, participants were, however, not matched on any other variable. Outcome assessors were not blinded and the distractor conditions and nodistractor conditions may have been not much different. The accuracy and direction of the results should be interpreted with caution as findings are based on one study only.

\section{Language}

Several studies have explored the association between a music intervention or music training and performance on (specific) language skills respectively, with contradictory findings. With regard to first language skills, results of an RCT by Cogo-Moreira et al. (2013) [21] showed positive growing slopes in

Portuguese language in the children who completed a 5-month music education program in comparison to the control children. Findings were in contrast to the results of Yang et al. (2014) [43] who, using a non-randomized, longitudinal design, examined the relation between long-term music training and, among other skills, academic development of Chinese language among 250 Chinese elementary school 
students (mean age 78 months). Children who took part in formal music training out of school around the beginning of semester three, were categorized as musician children ( $n=77$ ) whereas the remaining children, who had not received formal music training throughout this study, were categorized as non-musician children ( $n=173)$. Music training was not related to the enhancement of performance on Chinese language. Regarding second language abilities, Swaminathan \& Gopinath (2013) [44] explored second-language abilities of musically trained children ( $n=37$ )(mean age 100.55 months), who reported at least 3 months of music training and speaking a language other than English at home, and untrained children ( $n=39)$ (mean age 98.89 months) and found that the musically trained children (mean length of training 17.63 months) performed significantly better on the tests of comprehension and vocabulary compared to their untrained counterparts. The advantage persisted even when the trained group only consisted of participants trained in Indian Classical music, indicating that the English L2 advantage was not merely because of an increased opportunity to learn new words from songs as Indian

Classical music is written in Indian languages. Positive findings were also reported by Yang et al. (2014) [43], who found that musician children outperformed nonmusician children on second language development. Two studies [21] [43] reported contradictory results on the potential benefit of music on first language development. However, only findings from Cogo-Moreira et al. (2013) [21], conducting an RCT, allow for conclusions to be drawn about causality. Although the duration and sample size of Yang et al. (2014) [43] can be considered as strengths, participants were not randomized and a passive control was included. Another two studies reported positive results on second language development [43] [44]. Both studies made a comparison of the music group with a control group, who had no previous musical training. However, only one study [44] controlled for several baseline variables and used blinded outcome assessors, thereby increasing the validity of their findings.

\section{Mathematics}

Four studies have explored the effects of music on mathematics. A longitudinal study of Bergman Nutley et al. (2014) [35] yielded a positive association between music training (i.e., the number of hours per week of practice on instruments played) and performance on mathematics. Cogo-Moreira et al. (2013)

[21] also observed positive growing slopes in math grades. In Yang et al's (2014) [43] 
study, however, music training was not related to performance on mathematics. Courey et al. (2012) [41] examined the efficacy of a music intervention aimed to teach fractions to third graders using a quasi-experimental design. Sixty-seven 8-11 year-olds were assigned by class to either a 6-week academic music intervention, administered during regularly scheduled mathematics instruction, or continued their regular mathematics instruction with their classroom teacher. The experimental group outperformed the comparison group on music notation knowledge and the mathematical fraction completion test (i.e., not previously introduced and improper fractions). No significant group differences were found on the mathematical fraction concept test. The four studies reviewed yielded mixed results. One RCT [21] reported positive results. The remaining three studies were (longitudinal) quasi-experimental without randomization [41] [43] and longitudinal developmental [35]. Of these three studies, one found a positive association [35], one found partial positive results [41], and one found no relation [43]. Only one of these three studies included an active control group [41]. The duration and sample sizes of two out of these three studies can be considered as strengths [43] [35]. Although possible causal relations could be tested more easily, caution is needed in interpreting findings of Bergman Nutley et al. (2014) [35], due to attrition and possible practice effects.

\section{Other, Non-musical, Related Skills}

Two studies were identified that examined the effects of music on other, specific skills. Slater et al. (2015) [46] conducted a controlled, longitudinal study to investigate the effect of music training on speech in noise perception in 38 eight year-old children, randomly assigned to the music training program $(n=19)$ or the wait-list control group $(n=19)$. The authors reported a significant improvement of hearing in noise after 2 years of music training (Slater et al., 2015). Another longitudinal study of François et al. (2013) [45] tracked 24 eight year-old children after they were pseudo-randomly assigned to either a music training program or a painting program. They found that performance on both behavioural and electrophysiological measures of speech segmentation (i.e., the ability to extract meaningless words from a continuous flow of non-sense syllables) steadily increased across the testing sessions for the music group compared to the painting group. Both studies, reporting positive results, employed a 2-year, longitudinal design and used valid (computer) measures to evaluate the performance of participants. 
Randomization, thereby reducing the risk of sampling bias, was used only in one study [46]. Information about the blinding of outcome assessors was not reported and only one out of the two studies employed an active control group [45]. Although sample sizes can be considered small, thereby limiting the external validity of findings, both studies propose an interesting direction for further research.

\section{Discussion}

This review analysed the evidence of 46 studies, dealing with five developmental domains, including the motor, social, cognitive, language, and academic domain. With regard to the motor domain, the two studies identified suggested a positive influence of music interventions on specific motor skills (eye-hand motor sequences, discrete and continuous movements) [1] [2]. Due to the quasi-experimental design of the studies, the limited sample of participants and the inclusion of an active control group in one subexperiment of one study only [1], clear conclusions cannot be drawn.

It cannot be concluded whether music interventions can positively influence social and emotional development as results of the nine studies reviewed [3] [4] [5] [6] [7] [8] [9] [42] are inconclusive. The findings of two experimental studies [3] [6] suggest a beneficial impact of music interventions on empathy and spontaneous cooperative and helpful behaviour. The merging of the active and passive control group into one control group and the small sample size in one of the two studies, should, however, be taken into consideration. Positive findings of another study [7] turned out to be related to the level of cognitive functioning of participants in the music group. Caution is needed in drawing conclusions from the partially positive findings of Ritblatt et al. (2013) [4] and Schellenberg et al. (2015) [5] due to the design used [5] and the representativeness of the sample [4]. Two other experimental studies [8] [42] found modest effects and no effects, respectively, on social skills and self-esteem. Regarding the language domain, 15 studies evaluating the impact of music interventions on phonological awareness and auditory processing and reading skills [12] [15] [16] [17] [18] [19] [20] [22] [23] [35], and no clear conclusions can be drawn in this area. The results of two randomized controlled trials are inconclusive. The results of four experimental studies with (stratified) randomization [13] [11] [20] [23] suggested beneficial effects of music interventions on reading skills [20] [23], however, not on phonological skills [11] [13]. Of these four studies, two included both an active and a passive control group [13] [23], allowing for a more comprehensive 
comparison. Of the remaining six studies, quasi-experimental (longitudinal) without randomization [10] [14] [16] [18] [22] and developmental longitudinal [35] in nature, three point to the beneficial effects of music [16] [18] [22]. The other three studies, including an active [10] or both an active and passive control group [14] or comparing participants to themselves [35], found no impact of music interventions.

With regard to the cognitive domain, seven studies reviewed provided insufficient information whether music can have a positive effect on intelligence. The results of an RCT [21] showed no effects and two experimental studies, only one of them including an active control group, yielded mixed results [30] [42]. Evidence of three quasiexperimental (longitudinal) studies [24] [25] [26] and Iongitudinal developmental study suggest a (partially) positive influence of music. However, an active control group was included in just one of these three studies [25]. Evidence of five (quasi-) experimental longitudinal studies seem to suggest potential benefits of music on memory. However, due to lowering generalizability of findings on one study [32], by including participants with Williams syndrome only, and methodological limitations of the other four studies (i.e., no randomization [1] [30] [31] [33] and/or no inclusion of an active control group [30] [31]), clear conclusions cannot be made. Among the six quasi-experimental studies exploring

the potential influence of music on attention and EF skills, only two studies [25] [38] reported positive results. An additional five studies on working memory also seemed to suggest a positive influence. Whether or not an active control was included, the lack of randomization and the fact that working memory, attention and EF skills are difficult concepts to define, may have influenced the results obtained.

Regarding academic performance, research suggests some possible beneficial effects of music, although precise conclusions cannot be reached on the basis of reviewed studies. It cannot be concluded whether participation in a music program had a positive effect on promoting a positive approach due to the lack of randomization, the representativeness of the sample, the potential influence of parental and teacher expectations and the fact that the findings are based one study only [4]. The studies evaluating the impact of music interventions on first and second language development showed mixed findings. Regarding first language development, an RCT showed a positive effect, whereas a longitudinal study of Yang et al. (2014) reported no effects. Another two quasi-experimental studies showed improvement in second language performance [43] [44]. However, both studies included a passive control group. Of the four studies 
exploring the influence of music interventions on mathematics,

one RCT reported positive effects [21]. Caution is needed in making causal inferences on the three remaining studies [41] [43] [35] due to the design used, the absence of randomization [41] [43] and, with regard to the study of Bergman Nutley et al. (2014) [35], attrition rate and possible practice effects. Evidence from the studies regarding the effectiveness of music on language and mathematics are reviewed separately. One can question whether there is a legitimate distinction between the two domains, as research suggest partial overlap between neural regions associated with language and arithmetic (Baldo \& Dronkers, 2007; Cummine et al., 2014).

Five studies used a correlational design [9] [12] [15] [19] [37], reporting (partially) positive correlations between duration of music intervention and performance on reading and phonological awareness tasks, attention behaviour, and self-esteem. Although correlational studies can provide an indication of a possible association between musical training and functioning domains, they do not allow for causal inferences.

The tool used for the methodological quality assessment allowed scoring between zero and five only. This makes a cut-off point difficult to determine. Although all domains included studies with lower quality scoring (two or less), these were more frequently found in the social and cognitive domain. This, however, does not mean that the results of these studies are invalid, but rather gives a direct for reading

and interpreting them. The lower score of the study could often be explained by either unbalanced baseline characteristics, absence of randomization or missing information about blinding of outcome assessors or attrition rate. When analysing the outcomes of the quality screening, one should take into

consideration that it can be assessed with a broad range of tools. Upon applying the chosen tool, it was found that some of the items were difficult to relate to the studies at hand, but were more suitable for classical medical trials. Several criteria (including concealment of allocation and intention to treat) were negatively assessed in almost all studies, as they were not designed for the specifics of educational studies, where often it is impossible to ensure the rigid methodological quality: i.e., create double blind randomized trials.

When assessing the quality of the studied, there are several considerations regarding study design, music interventions, and the role of the teacher. In reporting on the participants, we found that little is mentioned about the intrinsic motivation of participants 
in the context of the intervention. As intrinsic motivation is associated with initiation and persistence of activities, level of effort and improved performance (Patall et al., 2008), gaining insight into the motivation of participants is important to be able to determine its impact on outcome measures. In some studies, interventions were partially provided by the authors themselves [1] [3] [6] [10] [22] [28] [36], or by parents and teachers [4]. As their expectations can have an effect on the performance of participants (the "Rosenthal effect"), one needs to be aware that observer bias rather than the intervention could cause the observed changes. Results of several studies might also have been affected by the "Hawthorne effect" i.e., a tendency of participants to alter their behaviour because they are aware that they are studied. This effect cannot be ruled out or confirmed for diverse studies after screening.

Most of the study designs consisted of quasi-experimental and longitudinal designs and three studies were RCTs. An RCT is considered as providing the strongest evidence of determining whether a cause-effect relationship exists between an intervention and outcomes (Sibbald \& Roland, 1998) as assessment bias and confounding are minimalized. However, some research questions and settings don't permit random assignment of participants and questions may arise about the sample being representative enough of the population and the generalizability of findings to the field. As it is important to consider evidence from other methodologies as well to better understand the potential of music interventions in practice, only an RCT allows the observed effects to be causally attributed to differences between the intervention and the control group(s).

In reviewed studies, active and/or passive control groups were included in evaluating the effectiveness of a music intervention. Although showing whether participants benefit from an intervention compared to participants not receiving the intervention, passive control groups do not allow to test for intervention specific effects (Strobach \& Karbach, 2016). Inclusion of an active control group, engaging participants in some training and activities during the intervention, can provide evidence as to whether an intervention is relatively more efficient than participating in another program (Karlsson \& Bergmark, 2015), provided that the intervention and control group are matched on possible influencing factors and perform the same tasks.

Regarding the music interventions, studies were not uniform in their conceptualization of these music interventions. Some were very broadly defined and included listening, singing, instrumental playing, performing, movement, and musical creativity. While others, especially focused on the acquisition of non-musical skills, were more precisely 
defined and designed. Differences in musical content deserve attention in likely contributing to the outcomes of music interventions. Interventions in groups may have additional benefits of social interaction and motivation above the intervention itself compared to individual interventions which could have played a role in its final outcomes. In this review, the role of the teacher also emerged as a significant issue. Eighteen of the included studies employed (professional) music teachers and 16 reported at least partly positive outcomes. Teaching music requires many competencies. Strong teaching skills without musical skills and knowledge is not sufficient and vice versa. Research points not only to musical content knowledge, but also to pedagogical content knowledge and non-pedagogical professional knowledge (Ballantyne \& Packer, 2004). By the way they teach, they play an important role in the teacher-child relationship which may have in turn implications for children's behavioural and academic adjustment (Furrer \& Skinner, 2003). Therefore, teachers may also be an important factor in the context in which the effectiveness of music interventions is researched.

Another point of attention when describing the effects of music interventions on the development of children is the methodological accuracy and variety of different approaches the researchers took in their studies. Being the most powerful research design for evaluating interventions, further RCTs are needed to determine whether music interventions are effective in stimulating development in children. However, particularly in the domain of music interventions in schools, some requirements such as blinding, randomization, and controlling for potential sources of variability are often difficult if not impossible to

achieve and RCTs may create an artificial situation in which findings may not always be applied to everyday practice. While we acknowledge the need for high-quality research methodology, it is important to find a balance between the externally imposed methodological standards and the drive to investigate

a said phenomenon in its natural environment. As qualitative research can provide more insight into the characteristics of the intervention and can generate potential hypotheses for quantitative research, combining qualitative and quantitative research can give more comprehensive and integrated insights in potential effects of music interventions.

In conclusion, although the underlying mechanisms are not always clear, evidence of reviewed studies seems suggestive of some beneficial effects. Having a clearer view of effects and possible influencing factors may pave the way for further research on the influence of music on the developing child. 


\section{References}

Baldo, J. V., \& Dronkers, N. F. (2007). Neural correlates of arithmetic and language comprehension: a common substrate? Neuropsychologia 45(2), 229-235. DOI: 10.1016/j. neuropsychologia.2006.07.014

Ballantyne, J., \& Packer, J. (2004). Effectiveness of preservice music teacher education programs: perceptions of early-career music teachers. Music Education Research, 6(3), 299-312. DOI: 10.1080/1461380042000281749

Bergman Nutley, S., Darki, F., \& Klingberg, T. (2014). Music practice is associated with development of working memory during childhood and adolescence. Frontiers in Human Neuroscience, 7:926. DOI: 10.3389/fnhum.2013.00926

Besson, M., Chobert, J., \& Marie, C. (2011). Transfer of training between music and speech: common processing, attention, and memory. Frontiers in Psychology, 2:94. DOI: 10.3389/fpsyg.2011.00094

Bhide, A., Power, A., \& Goswami, U. (2013). A rhythmic musical intervention for poor readers: a comparison of efficacy with a letter-based intervention. Mind, Brain and Education, 7(2), 113123. DOl: $10.1111 / \mathrm{mbe} .12016$

Bonacina, S., Cancer, A., Lanzi, P. L., Lorusso, M. L., \& Antonietti, A. (2015). Improving reading skills in students with dyslexia: the efficacy of a sublexical training with rhythmic background. Frontiers in Psychology, 6:1510. DOI: 10.3389/fpsyg.2015.01510

Brodsky, W., \& Sulkin, I. (2011). Handclapping songs: a spontaneous platform for child development among 5-10-year-old children. Early Child Development and Care, 181(8), 1111-1136. doi: 10.1080/03004430.2010.517837

Bugos, J., \& Jacobs, E. (2012). Composition instruction and cognitive performance: results of a pilot study. Research and Issues in Music Education, 10:2. Available online at: http://ir.stthomas.edu/ rime/vol10/iss $1 / 2$

Cogo-Moreira, H., Andriolo, R. B., Yazigi, L., Ploubidis, G. B., Brandão de Ávila, C. R., \& Mari, J. J. (2012). Music education for improving reading skills in children and adolescents with dyslexia. Cochrane Database of Systematic Reviews, 8:15:CD009133. doi: 10.1002/14651858.CD009133.pub2

Cogo-Moreira, H., Brandão de Ávila, C. R., Ploubidis, G. B., \& Mari, J. D. J. (2013). Effectiveness of music education for the improvement of reading skills and academic achievement in young poor readers: a pragmatic cluster-randomized, controlled clinical trial. PLoS ONE 8:e59984. DOI: 10.1371/journal.pone.0059984

Corrigall, K. A., \& Trainor, L. J. (2011). Associations between length of music training and reading skills in children. Music Perception: An Interdisciplinary Journal, 29(2), 147-155. DOI: 10.1525/ mp.2011.29.2.147

Costa-Giomi, E. (2004). Effects of three years of piano instruction on children's academic achievement, school performance and self-esteem. Psychology of Music 32(2), 139-152. DOI: 10.1177/0305735604041491

Courey, S. J., Balogh, E., Siker, J. R., \& Paik, J. (2012). Academic music: music instruction to engage thirdgrade students in learning basic fraction concepts. Educational Studies in Mathematics, 81(2), 251-278. DOI: 10.1007/s10649-012-9395-9 
Cummine, J., Szepesvari, E., Chouinard, B., Hanif, W., \& Georgiou, G. K. (2014). A functional investigation of RAN letters, digits, and objects: how similar are they? Behavioural Brain Research, 275, 157165. DOI: 10.1016/j.bbr.2014. 08.038

Degé, F., \& Schwarzer, G. (2011). The effect of a music program on phonological awareness in preschoolers. Frontiers In Psychology, 2:124. DOl: 10.3389/fpsyg.2011.00124

Degé, F., Wehrum, S., Stark, R., \& Schwarzer, G. (2011). The influence of two years of school music training in secondary school on visual and auditory memory. European Journal of Developmental Psychology, 8(5), 608-623. DOI: 10.1080/17405629.2011.590668

Degé, F., Wehrum, S., Stark, R., \& Schwarzer, G. (2014). Music lessons and academic self-concept in 12-to 14-year-old children. Musicae Scientiae, 18(2), 203-215. DOI: 10.1177/1029864914523283

Escalda, J., Lemos, S. M. A., \& França, C. C. (2011). Auditory processing and phonological awareness skills of five-year-old children with and without musical experience. Jornal da Sociedade Brasileira de Fonoaudiologia, 23(3), 258-263. DOI: 10.1590/S2179-64912011000300012

Flaugnacco, E., Lopez, L., Terribili, C., Montico, M., Zoia, S., \& Schön, D. (2015). Music training increases phonological awareness and reading skills in developmental dyslexia: a randomized control trial. PLOS ONE, 10:e0138715. DOI: 10.1371/journal.pone.0138715

Fonseca-Mora, M. C., Jara-Jiménez, P., \& Gómez-Domínguez, M. (2015). Musical plus phonological input for young foreign language readers. Frontiers in Psychology, 6:286. DOI: 10.3389/ fpsyg.2015.00286

Forgeard, M., Winner, E., Norton, A., \& Schlaug, G. (2008). Practicing a musical instrument in childhood is associated with enhanced verbal ability and nonverbal reasoning. PLOS ONE, 3:e3566. DOI: 10.1371/journal.pone.0003566

François, C., Chobert, J., Besson, M., \& Schön, D. (2013). Music training for the development of speech segmentation. Cerebral. Cortex, 23(9), 2038-2043. DOI: 10.1093/cercor/bhs180

Furrer, C., \& Skinner, E. (2003). Sense of relatedness as a factor in children's academic engagement and performance. Journal of Educational Psychology, 95(1), 148-162. DOI: 10.1037/00220663.95.1.148

Gioia, G. A., Isquith, P. K., Guy, S. C., \& Kenworthy, L. (2000). Behavior Rating Inventory of Executive Function: Professional Manual. Lutz, FL: Psychological Assessment.

Grant, M. J., \& Booth, A. (2009). A typology of reviews: an analysis of 14 review types and associated methodologies. Health Information \& Libraries Journal, 26(2), 91-108. DOI: 10.1111/j.14711842.2009.00848.x

Habib, M., Lardy, C., Desiles, T., Commeiras, C., Chobert,. J., \& Besson, M. (2016).Music and Dyslexia: a new musical training method to improve reading and related disorders. Frontiers in Psychology, 7:26. DOI: $10.3389 /$ fpsyg.2016.00026

Herrera, L., Lorenzo, O., Defior, S., Fernandez-Smith, G., \& Costa-Giomi, E. (2011). Effects of phonological and musical training on the reading readiness of native-and foreign-Spanishspeaking children. Psychology of Music, 39(1), 68-81. DOI: 10.1177/0305735610361995

Ho, Y. C., Cheung, M. C., \& Chan, A. S. (2003). Music training improves verbal but not visual memory: cross-sectional and longitudinal explorations in children. Neuropsychology, 17(3), 439-450. DOI: 10.1037/0894-4105.17.3.439 
Janus,M., Lee, Y.,Moreno, S., \& Bialystok, E. (2016). Effects of short-term music and second-language training on executive control. Journal of Experimental Child Psychology, 144, 84-97. DOI: 10.1016/j.jecp.2015.11.009

Janzen, T. B., Thompson,W. F., \& Ranvaud, R. (2014). A developmental study of the effect of music training on timed movements. Frontiers in Human Neuroscience, 8:801. DOI: 10.3389/ fnhum.2014.00801

Jaschke, A. C., Eggermont, L. H., Honing, H., \& Scherder, E. J. (2013). Music education and its effect on intellectual abilities in children: a systematic review. Reviews in the Neuroscience, 24(6), 665-675. DOI: 10.1515/revneuro-2013-0023

Jentschke, S., \& Koelsch, S. (2009). Musical training modulates the development of syntax processing in children. Neuroimage 47(2), 735-744. DOI: 10.1016/j.neuroimage.2009.04.090

Karlsson, P., \& Bergmark, A. (2015). Compared with what? An analysis of control-group types in Cochrane and Campbell reviews of psychosocial treatment efficacy with substance use disorders. Addiction, 110(3), 420-428. DOI: 10.1111/add.12799

Kaviani, H., Mirbaha, H., Pournaseh, M., \& Sagan, O. (2014). Can music lessons increase the performance of preschool children in IQ tests? Cognitve Processing, 15(1), 77-84. DOI: 10.1007/ s10339-013-0574-0

Khalil, A. K., Minces, V., McLoughlin, G., \& Chiba, A. (2013). Group rhythmic synchrony and attention in children. Frontiers in Psychology, 4:564. DOI: 10.3389/fpsyg.2013.00564

Kirschner, S., \& Tomasello, M. (2010). Joint music making promotes prosocial behavior in 4-year-old children. Evolution and HumanBehavior, 31(5),354-364.DOI:10.1016/j.evolhumbehav.2010.04.004

Maloy, M., \& Peterson, R. (2014). A meta-analysis of the effectiveness of music interventions for children and adolescents with attention-deficit/hyperactivity disorder. Music, Mind, and Brain, 24(4), 328-339. DOI: 10.1037/pmu0000083

Martens, M. A., Jungers, M. K., \& Steele, A. L. (2011). Effect of musical experience on verbal memory in Williams syndrome: evidence from a novel word learning task. Neuropsychologia, 49(11), 30933102. DOI: 10.1016/j.neuropsychologia.2011.07.016

Mehr, S. A., Schachner, A., Katz, R. C., \& Spelke, E. S. (2013). Two randomized trials provide no consistent evidence for nonmusical cognitive benefits of brief preschool music enrichment. PLOS ONE, 8:e82007. DOI: 10.1371/journal.pone.0082007

Melnyk, B. M., \& Fineout-Overholt, E. (2005). Making the case for evidence based practice. In B. M. Melnyk \& E. Fineout-Overholt (Eds.), Evidence-Based Practice in Nursing and Healthcare: A Guide to Best Practice (3-24). New York, NY: Lippincott; Williams \& Wilkins.

Miendlarzewska, E. A., \& Trost, W. J. (2014). How musical training affects cognitive development: rhythm, reward and other modulating variables. Frontiers in Neuroscience, 7:279. DOI: 10.3389/ fnins.2013.00279

Moreno, S., Bialystok, E., Barac, R., Schellenberg, E. G., Cepeda, N. J., \& Chau, T. (2011a). Short-term music training enhances verbal intelligence and executive function. Psychological Sciences, 22(11), 1425-1433. DOI: 10.1177/0956797611416999

Moreno, S., Friesen, D., \& Bialystok, E. (2011 b). Effect of music training on promoting preliteracy skills: preliminary causal evidence. Music Perception: An Interdisciplinary Journal, 29(2), 165-172. DOI: 


\subsection{5/mp.2011.29.2.165}

Moritz, C., Yampolsky, S., Papadelis, G., Thomson, J., \& Wolf, M. (2013). Links between early rhythm skills, musical training, and phonological awareness. Reading and Writing, 26(5), 739-769. DOI: $10.1007 / \mathrm{s} 11145-012-9389-0$

Patall, E. A., Cooper, H., \& Robinson, J. C. (2008). The effects of choice on intrinsic motivation and related outcomes: a meta-analysis of research findings. Psychological Bulletin, 134(2), 270-300. DOI: $10.1037 / 0033-2909.134 .2 .270$

Pelham, W. E. Jr., Waschbusch, D. A., Hoza, B., Gnagy, E. M., Greiner, A. R., Sams, S. E., et al. (2011). Music and video as distractors for boys with ADHD in the classroom: comparison with controls, individual differences, and medication effects. Journal of Abnormal Child Psychology, 39(8), 10851098. DOI: 10.1007/s10802-011-9529-z

Portowitz, A., Peppler, K. A., \& Downton,M. (2014). In Harmony: a technology based music education model to enhance musical understanding and general learning skills. International Journal of Music Education, 32(2), 242-260. DOI: 10.1177/0255761413517056

Rabinowitch, T. C., Cross, I., \& Burnard, P. (2013). Long-term musical group interaction has a positive influence on empathy in children. Psychology of Music, 41(4), 484-498. DOI: $10.1177 / 0305735612440609$

Rautenberg, I. (2013). The effects of musical training on the decoding skills of German-speaking primary school children. Journal of Research in Reading, 38(1), 1-17. DOl: 10.1111/jrir.12010

Rickard, N. S., Appelman, P., James, R., Murphy, F., Gill, A., \& Bambrick, C. (2013). Orchestrating life skills: the effect of increased school-based music classes on children's social competence and self-esteem. International Journal of Music Education, 31(3), 292-309. DOI: 10.1177/0255761411434824

Rickard, N. S., Bambrick, C. J., \& Gill, A. (2012). Absence of widespread psychosocial and cognitive effects of school-based music instruction in 10-13-year-old students. International Journal of Music Education, 30(1), 57-78. DOI: 10.1177/0255761411431399

Rickard, N. S., Vasquez, J. T., Murphy, F., Gill, A., \& Toukhsati, S. R. (2010). Benefits of a classroom based instrumental music program on verbal memory of primary school children: a longitudinal study. Australian Journal of Music Education, 1, 36-47.

Ritblatt, S., Longstreth, S., Hokoda, A., Cannon, B. N., \& Weston, J. (2013). Can music enhance schoolreadiness socioemotional skills? Journal of Research in Childhood Education, 27(3), 257-266. DOI: $10.1080 / 02568543.2013 .796333$

Roden, I., Grube, D., Bongard, S., \& Kreutz, G. (2014). Does music training enhance working memory performance? Findings from a quasi-experimental longitudinal study. Psychology of Music, 42(2), 284-298. DOI: 10.1177/0305735612471239

Roden, I., Kreutz, G., \& Bongard, S. (2012). Effects of a school based instrumental music program on verbal and visual memory in primary school children: a longitudinal study. Frontiers in Psychology, 3:572. DOI: 10.3389/fpsyg.2012.00572

Särkämö, T., Ripollés, P., Vepsäläinen, H., Autti, T., Silvennoinen, H. M., Salli, E., et al. (2014). Structural changes induced by daily music listening in the recovering brain after middle cerebral artery stroke: a voxel-based morphometry study. Frontiers in Human Neuroscience, 8:245. DOl: 10.3389/fnhum.2014.00245 
Schellenberg, E. G. (2004). Music lessons enhance IQ. Psychological Science, 15(8), 511-514. DOI: 10.1111/j.0956-7976.2004.00711.x

Schellenberg, E. G. (2011). Examining the association between music lessons and intelligence. British Journal of Psychology, 102(3), 283-302. DOI: 10.1111/j.2044-8295.2010.02000.x

Schellenberg, E. G., \& Mankarious, M. (2012). Music training and emotion comprehension in childhood. Emotion, 12(5), 887-891. DOI: 10.1037/a0027971

Schellenberg, E. G., Corrigall, K. A., Dys, S. P., \& Malti, T. (2015). Group music training and children's prosocial skills. PLOS ONE, 10:e0141449. DOI: 10.1371/journal.pone.0141449

Sibbald, B., \& Roland, M. (1998). Understanding controlled trials: why are randomised controlled trials important? BMJ: British Medical Journal, 316(7126), 201. DOI: 10.1136/bmj.316.7126.201

Slater, J., Skoe, E., Strait, D. L., O'Connell, S., Thompson, E., \& Kraus, N. (2015). Music training improves speech-in-noise perception: longitudinal evidence from a community-based music program. Behavioural Brain Research, 291, 244-252. DOI: 10.1016/j.bbr.2015.05.026

Slater, J., Strait, D. L., Skoe, E., O'Connell, S., Thompson, E., \& Kraus, N. (2014). Longitudinal effects of group music instruction on literacy skills in low-income children. PLOS ONE, 9:e113383. DOI: 10.1371/journal.pone.0113383

Southgate, D. E., \& Roscigno, V. J. (2009). The impact of music on childhood and adolescent achievement. Social Science Quarterly, 90(1), 4-21. DOI: 10.1111/j.1540-6237.2009.00598.x

Standley, J. M. (2008). Does music instruction help children learn to read? Evidence of a meta-analysis. Update: Applications of Research in Music Education, 27(1), 17-32. DOI: 10.1177/8755123308322270

Strait, D. L., Kraus, N., Parbery-Clark, A., \& Ashley, R. (2010). Musical experience shapes top-down auditory mechanisms: evidence from masking and auditory attention performance. Hearing Research, 261(1-2), 22-29. DOI: 10.1016/j.heares.2009.12.021

Strobach, T., \& Karbach, J. (2016). Cognitive Training: An Overview of Features and Applications. Berlin: Springer-Verlag.

Suthers, L., \& Niland, A. (2007). An exploration of young children's engagement with music experiences. In K. Smithrim \& R. Upitis (Eds.), Listen to their Voices: Research and Practice in Early childhood Music (19-32). Waterloo, ON: Canadian Music Educators' Association.

Swaminathan, S., \& Gopinath,J. K. (2013). Music training and second-language English comprehension and vocabulary skills in Indian children. Psychological Studies, 58(2), 164-170. DOI: 10.1007/ s12646-013-0180-3

Yang, H., Ma, W., Gong, D., Hu, J., \& Yao, D. (2014). A Longitudinal study on children's music training experience and academic development. Scientific Reports, 4:5854. DOI: 10.1038/srep05854

Yazejian, N., \& Peisner-Feinberg, E. S. (2009). Effects of a preschool music and movement curriculum on children's language skills. NHSA Dialog, 12(4), 327-341. DOI: 10.1080/15240750903075255

Zuk, J., Benjamin, C., Kenyon, A., \& Gaab, N. (2014). Behavioral and neural correlates of executive functioning in musicians and non-musicians. PLOS ONE, 9:e99868. DOI: 10.1371/journal. pone.0099868 


\section{CHAPTER 3}

\section{Special Music Education: A Prelude to a New Perspective?}

\section{Published as:}

Dumont, E.H., van Hooren, S, Stuijts, M. \& Feron, F. (2015). Orthopedagogische Muziekbeoefening: een opmaat voor een nieuw perspectief? Tijdschrift voor Orthopedagogiek, 54, 373-383 [original article in Dutch] 


\section{Abstract}

This article offers a closer look into special music education (SME) and the potential which SME may hold for children with special educational needs. In this study, two focus groups were formed of SME teachers and SME students. The participants entered into discussions about views, attitudes and experiences regarding SME. Analyses showed that within SME, three core factors can be distinguished: (1) music, (2) the SME teacher and (3) the child. In contextualizing SME, the setting has also proved to be relevant. Results suggest a promising perspective for a positive influence of SME on the neurocognitive functions, self-image and motivation of children. 


\section{Introduction}

Primary schools offer the pedagogical and educational support that children need to develop their study skills to their full potential. Some children, however, have special educational needs. Due to behavioural problems, learning difficulties and/or other reasons, they need more intensive support than mainstream education can offer. Special primary education uses pedagogical methods to meet these special needs. Taking a child's specific difficulties and abilities into consideration, methods, instructions and (learning) activities are adapted to improve the child's learning and development. Music also seems to offer possibilities to improve a child's development. Studies into the influence of music education on primary school children show positive effects on cognition, including intelligence and memory (Ho, Cheung \& Chan, 2003; Schellenberg, 2004), musical skills (Hyde et al., 2009) and motor skills (Brodsky \& Sulkin, 2011). Studies also seem to indicate effects on language (Chobert, Marie, Francois, Schön \& Besson, 2011) and arithmetic (Johnson \& Memmott, 2006). Research into the possible effects of music education on the personal and social development of children point towards a positive influence of music lessons on their sense of self-worth (Rickard, Appelman, James, Murphy, Gill \& Bambrick, 2012; Costa-Giomi, 2005). Creating a sense of belonging to a group and giving a child responsibility during music lessons are listed as factors which may lead to a greater sense of self-worth.

Although music education can be of great importance to the development of a child with special educational needs, it is often not or no longer part of the curriculum. In many primary schools, music education has (all but) disappeared due to cutbacks (Haaij, Hiemstra \& Slob, 2012). It is not always a given that music education is provided by a specialist teacher, partly due to limited resources. Music lessons are often taught by class teachers. Research shows that many class teachers are insecure about their skills when it comes to providing music education for their class, partly because little attention is paid to the subject during teacher training (Haaij et al., 2012). This insecurity may cause teachers to pay less attention to the subject of music in general, or to a particular area of music, such as singing or moving to music (Haaij et al., 2012; Van Schilt-Mol, 2012). A specialist teacher trained in music education at a music academy can provide more purposeful music education. Particularly in special education, it is important to place music education within the framework of an educational question or aim (Rutten \& Stuijts, 2014). This is exactly what SME teachers do. As well as developing music skills, they stimulate children's social, cognitive and 
sensorimotor development. An SME teacher is capable of tailoring music lessons specifically to the development and abilities of a child with special educational needs.

In practice, SME teachers and SME students report positive experiences with the use of SME on children with special educational needs. In view of these experiences, as well as the scientifically proven effects of music, SME may be of great importance to this target group. Systematic research into SME and the possible contributing factors to achieving these positive effects is, however, absent. This study aims to create more clarity. The first objective of this study is to explore the methods and related lines of reasoning used in SME, and to make these more explicit. Our second objective was to examine what potential SME may hold for children with special educational needs.

\section{Methods}

Our chosen method was to conduct qualitative research using focus groups. This choice was connected with the open research question and the wish to gain insight into what a target group considers important and why. Within this qualitative method, the decision was taken to use the grounded theory approach (Wester, 1987; Corbin \& Strauss, 2008). The purpose of this approach is to develop a theory based on phenomena in the field. Instead of starting from pre-determined hypotheses, it starts from a rough idea which is defined and tested as the process unfolds.

In this study, two focus groups were formed in which participants discussed the methods and views regarding SME. The use of focus groups offered opportunities for insight into participants' (personal) experiences, motivations, expectations, and underlying views. The fact that they had the chance to respond to each other's statements enabled exploration of many aspects of the topic offered.

\section{Participants}

Focus group A consisted of four female students in the third year of the Music in Education programme at the Maastricht Academy of Music, specializing in SME. Their ages ranged from 20 to 22 years old. The average age of the students was 21.25 years old (SD 0.82). At the time of the study, all of these students were doing teaching practice in secondary and special primary education.

Focus group B consisted of five participants. Four of those five participants completed 
the Music in Education programme, specializing in SME, in the 2006-2011 period. One participant had a degree in music education and solo singing, as well as being qualified to work in creative therapy training. Their ages ranged from 23 to 54 years old. The average age of the participants was 36.4 years old (SD12.2). At the time of the study, all the participants worked in (special) primary and secondary education. Their target groups included children with physical or multiple impairments, children with language, speech or hearing problems, children with learning and behavioural problems and children with developmental issues.

\section{Interviews}

The SME students and SME teachers were asked to participate by email or in person in October 2012. The research question of this study was taken into account when selecting participants. Apart from enrolment or a degree in an SME programme, no inclusion or exclusion criteria were set. Before the start of the meetings, it was decided to form two separate groups of students and teachers, respectively. The reason for this was that students, as is inherent in their position within the programme and their teaching practice, experience educational situations from a different perspective than educators. The meetings of both groups were held in the period from February to June 2013. The participants were informed and took part on a voluntary basis. One researcher (ED) moderated the focus groups.

The meeting started with an open question around the concept of SME. Following a starter question, the dialogue in the groups was left to run its course as much as possible. The moderator only intervened when she thought the content required clarification. The first meetings centered around exploring the concept of SME. In subsequent meetings, characteristics and themes which the groups considered relevant were explored in more detail. Step by step, points of view were explored and formed, but not with the goal of reaching consensus. Different visions were allowed to co-exist and be understood as part of the complexity of individual, subjective perception (Flaton \& Taylor, 2006). The focus groups followed a cyclical pattern, alternating data collection with analysis. This cycle was repeated several times to test findings. The meetings continued until no new insights occurred. The SME teachers group met seven times, while the SME student group had five meetings. All the meetings were recorded on an audio recording device and transcribed. 


\section{Data analysis}

The transcriptions were entered into the software program Kwalitan (Peters, 2000). This was followed by coding. In the first phase, open coding was applied to label and code relevant text fragments. The second phase consisted of axial coding, naming codes on a more abstract level, identifying categories, and relating categories to each other. Selective coding was performed in the last phase, giving more structure to the codes and identifying connections between (core) concepts in order to eventually establish the theoretical framework (Boeije, 2008; Corbin \& Strauss, 2008). The students' and professionals' verbata were analysed and coded simultaneously. The verbata analyses showed very few differences between the two groups. Any detected differences seemed to be connected to the students' specific positions within the degree programme. The reliability of the analysis and coding was tested through peer review, with several project members reading the same transcripts and discussing analyses together to create a shared framework of analysis (Meadows \& Morse, 2001). With regard to certain findings, literature was consulted to find the state of the art. Using literature strengthens the theoretical framework from a scientific perspective (Goede \& De Villiers, 2003). In order to validate the analysis, the findings were presented to the participants, who were asked whether they understood the findings and could relate these to their own experiences and perceptions. They were also asked to provide specific feedback, also known as a 'member check' (Meadow \& Morse, 2001). 


\section{Results}

The data analysis shows that three core factors can be distinguished within the SME process: (1) music, (2) the SME teachers and (3) the child. These concepts will be discussed separately below. The setting will also be examined in order to contextualize the SME process.

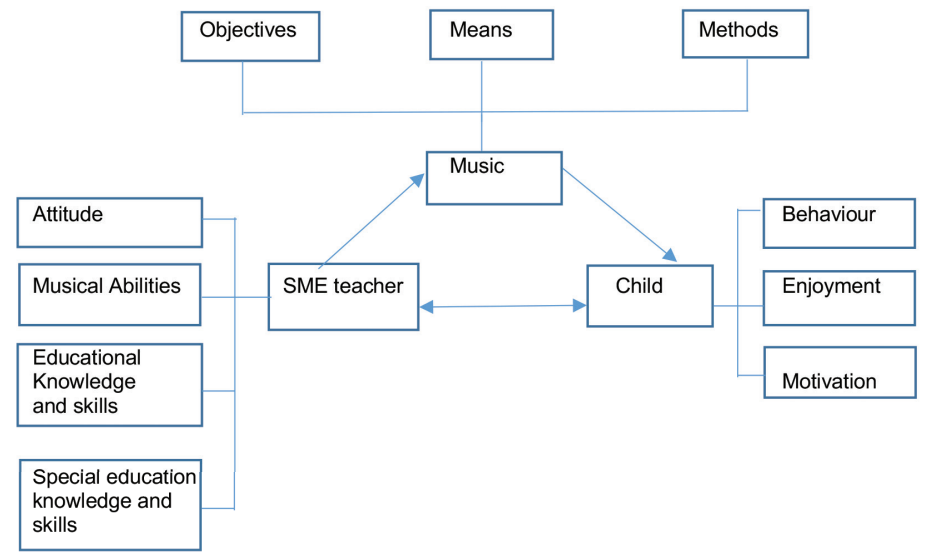

Figure 1 Visual representation of code relationships

\section{Music}

In SME, music is used as a way of stimulating a child's musical and extra-musical abilities. Apart from the fact that music can be a goal in itself, focusing on perception and enjoyment, it can also help children to develop musical as well as sensorimotor, social, and cognitive skills. The respondents underlined the versatility of music as a means to achieving these skills and goals. One of them phrased it as follows: What I like about music, is that you can use it in so many ways. You can do something with rhythm, do something with language, you can work on motor skills, focus on emotions. That makes music really accessible' (student, meeting 3, 29 May 2013).

SME teachers offer music activities individually as well as in a group, to work on musical and extra-musical objectives. All the respondents emphasized that differences in level, skills, and perception are inherent in a group in special education. That is why musical activities are adapted to the abilities, pace, and perception of the group, allowing each child to contribute at his/her own level to a shared musical product. For 
both the students and professionals, the focus is on making music together, rather than on what a child cannot do/finds difficult or where (s)he needs added support. When making music in a group, you can reach children at all levels. The great thing is that with music, you can create one product to which each child can contribute at its own level. In some things, that's just not possible. In an English test, the question and the answer to that question are set. With music, you can just... let him play only one note, but one that is really essential to the character of that song. You can choose that (song) specifically and make that child really happy, and it really adds somethings as well' (SME teacher, meeting 5, 8 May 2013). The respondents stated that making music can motivate and bring enjoyment. Listening to music can evoke associations or memories with linked emotions. Music also appeals to various functions; singing and playing rhythms and melodies, for example, engages aural perception processes, (working) memory, and concentration.

Music can be used in various ways; singing (together), playing an instrument, and moving or listening to music. These activities can be applied in a very structured or unstructured way. The respondents also pointed out that music has many components, including melody, rhythm, and dynamics, and that it can offer a clear structure, e.g. through a melody line.

\section{The SME teacher}

The respondents listed various skills which they feel an SME teacher should have. All respondents consider the attitude to be important. He/she must be able to create a learning environment in which students feel capable and are allowed to make mistakes. It is important for the SME teacher to make the child feel safe in this situation, to look out for verbal and non-verbal signals, try to understand these, and respond to them effectively. One respondent indicated: 'and constantly tuning in, right? Constantly checking whether you're still at the level of the child; is it lively, engaged, and if you see someone drifting off... that is SME... constantly tuning in' (SME teacher, meeting 1, 21 February 2013). Considering the wide range of problems in a class and the group dynamics present, it is also important for an SME teacher to show creativity and flexibility, and to be able to adjust his/her actions to the group without losing sight of the objective.

Apart from the right attitude, both the students and professionals feel it is essential for an SME teacher to have solid musical competencies, i.e. being able to play several 
instruments, having a good voice, knowing and being able to use music in various forms and methods, and having an extensive song repertoire. One respondent stated: 'That's a skill, it requires a lot of practice' (SME teacher, meeting 5, 8 May 2013). Apart from a technical command of the instruments and voice, both the SME students and SME teachers consider the ability to express oneself musically in sound and movement to be indispensable. '[..]. Being able to accompany songs in various keys, that's something you can learn. But you also need to be able to make contact. That contact, what you show of yourself in the music, that's where you touch each other (SME teacher, meeting 5, 8 May 2013).

Educational knowledge and teaching skills are considered important by all respondents. All respondents give whole-class instruction to a group. The children in this group, however, experience difficulties in different areas. SME teachers must be able to phrase and transfer information in such a way that it can be processed and understood by the child. An SME teacher also needs to be able to monitor and guide musical and other processes at both a group and individual level. Students as well as professionals feel that there is a lack of teaching materials for special primary education for them to fall back on. As their target group is heterogeneous, it is challenging to find one method that is suitable for the whole group. Partly using their experience, they tend to find their own solutions for this. Three quarters of the respondents adapt their lessons to the themes being discussed in school or in a particular class at that time, also to make sure they tie in with other subjects. In his/her actions, an SME teacher works towards that which he wants to achieve, both musically, with objectives being derived from the attainment targets, and extramusically, addressing children's difficulties and educational needs.

Knowledge and skills in the field of special education are deemed indispensable by all respondents. Students and teachers indicated that an SME teacher needs to be able to look into the (initial) situation of a child. He needs this information, obtained from his own (test) observations and/or consultations with colleagues, to put the child's behaviour into context. One respondent explains: 'because you have this background in special education, you know about a child's level of development, about disorders or developmental age. That tells you: for children of that developmental age, who are working on those things, it is important for me to tie in with what they are doing. If you don't, they won't be able to manage it' (SME teacher, meeting 4, 20 April 2013). Having background knowledge in itself, however, is not enough according to the respondents. An SME 
teacher also needs to know how to apply this information during a lesson, by using various, usually structured teaching formats.

\section{The child}

Special education serves children with a wide range of learning and/or behavioural problems. The result of this is a heterogeneous and complex target group. Respondents reported that nearly all children like and enjoy the subject of music. Both SME students and teachers indicated that music is a way for children to express and communicate feelings to each other. The child can literally make himself/herself heard and seen. It gives the child the opportunity to share experiences with other children, become motivated, and experience success. The child can make its own choices, show its individuality and contribute to a musical result. In short, this subject stimulates musical and extra-musical skills and gives the child the chance to show itself in a different way.

A safe class environment was listed as a condition by all respondents. Respondents see the added value of music lessons reflected in the motivation and behaviour of a child, among other things. One respondent indicated that 'children like working with music so much, it brings them so much, in terms of success, connection, experiences, that they are willing to take steps with regard to their behaviour..[...]. The power lies in what they experience when making music, that is what motivates them' (SME teacher, meeting 1, 21 February 2013).

All respondents stated that in music lessons, they had seen children being capable of doing things they found difficult before (in non-musical situations), without specifically practicing these. In terms of concrete behaviour, for example, some children are suddenly capable of bringing their things, being on time, 'or of taking responsibility by setting up or exchanging things' (SME teacher, meeting 1, 21 February 2013). One respondent indicated: 'when I have achieved something with a child, I didn't say to that child: this is what I plan to do with you and I'm going to use music for this. I get him involved in the music and suddenly something happens, and I think to myself: wait a minute, he had terrible trouble doing that earlier' (SME teacher, meeting 4, 20 April 2013). This points towards the SME teacher not consciously using musical activities a priori to stimulate certain behaviours in the child. The enjoyment the child experiences in the music lesson or while making music contributes to it almost inconspicuously. One respondent indicated: 'because they're having so much fun, they're not really aware that 
they're working on those things' (SME teacher, meeting 1, 21 February 2013).

As set out above, the SME teacher's attitude and responsiveness play a part in the interaction with the child. However, the child also influences this relationship. As one respondent put it: 'I just notice: whatever I offer them, musically as well, they will take it. They pick it up in their own way within their own abilities, and give it back to you' (student, meeting 1, 25 April 2013)

\section{Setting}

SME teachers are responsible for offering the subject of music in special education. Firstly, this comes with some practical requirements, such as a suitable space and instruments. Another important factor, according to the professionals, is consultation between an SME teacher and class teachers, as well as consultation with other disciplines, including the speech therapist, special education expert and school social worker. The target group within special (primary) education is diverse; children with learning difficulties, behavioural problems and/or physical impairments are placed together in a group, sometimes only temporarily. The group composition may change in the course of a single school year. On top of this, SME teachers see the children for an average of 45 minutes a week. Depending on the internal organisation of a school, the SME teacher or the class teachers may not have any influence on the group composition. Exchanging information about the group, the group dynamics and/or individual students with a class teacher, who sees the children on a daily basis, enables the SME teachers to use these findings in the approach he/she uses with the group. One respondent stated: 'I don't know everyone's files, but I exchange feedback with each class teacher every week. I think it's very important to hear the main points from them. It's important for me to know things like: parents who have split up, a child who has finally been diagnosed with an autistic spectrum disorder, or a child having ADHD or being on medication. These are things I feel are important to adjust to' (SME teacher, meeting 1, 21 February 2013). Both students and teachers indicated, however, that achieving this requires them to take an active role, and that weekly consultation with a class teacher is not a reality for all of them.

Within a school organisation, just like class teachers, SME teachers monitor their students' progress and have to be able to justify their interpretation of the subject. Respondents also reported that they feel the need to give their subject a (more) distinct profile within the school. This too requires them to take action. One of the 
respondents phrased it as follows: 'There comes a point where you have to stand up for your subject and show yourself...[.]. That was quite a struggle for me, getting on the Dot. com system with music because I want to be part of things. Writing it down over and over again, that suddenly made them take it a bit more seriously' (SME teacher, meeting 1, 21 February 2013). Two respondents felt that in their job, while there is scope for music education, it is not a high priority within the curriculum. One respondent stated: " sometimes have to put up a real fight just to be able to actually be there'. With regard to (justifying) their interpretation of the subject, one respondent feels a certain tension, because music is not that easy to fit into a common instructional model.

\section{Discussion}

The aim of the this study was to explore the concept of SME in more detail as well as to examine the potential added value of SME for children in special education. Respondents described experiences, elements they felt were important in SME, and their actions in their own words, without being offered a pre-structured list of topics. Results show that three core elements can be distinguished within SME: (1) music, (2) the SME teacher and (3) the child. The respondents perceive music as a means to reach children, with all their strengths and difficulties. Music is not only valuable when it comes to creating a musical end product, it is also an important means of stimulating musical and extra-musical skills. The respondents also stressed the importance of a solid musical background as well as the right attitude and the communication, observational, and teaching skills they feel an SME teacher should have. An SME teacher can introduce the child to various aspects of music and, based on this study, is the right person to join the child in its exploration, experimentation and stimulation during the music lessons. Due to a lack of suitable teaching materials, they often create their own lessons, setting both musical and non-musical objectives. The respondents stated that they can all see that children really enjoy music lessons and dare to show (more of) their individuality. Children learn to make and appreciate music (together). The schools where SME teachers work, vary in their endorsement of the importance of music education. All SME teachers feel the need to create a (more) distinct profile for their subject. The effects of SME were also explored. The respondents mentioned effects on memory, social interaction, and self-image; they see children being capable of being on time and remembering things. These experiences are in line with research. Research shows that music lessons have a 
positive effect on verbal memory (Brodsky \& Sulkin, 2011; Ho et al., 2003). They also see that children who take music lessons feel more (musically) competent. Although in some situations, musical activities can be used specifically to stimulate an area of development, the respondents stated that the above elements are not stimulated explicitly. Apart from a creative subject, SME also seems to be a subject in which children acquire extra-musical skills, such as skills related to attention and memory. Children seem to be unaware or hardly aware of this. Motivation seems to play an important part in the effects found. The influence of motivation is confirmed by the literature (Forgeard, Winner, Norton \& Schlaug, 2008; Hallam, 2010a). Hallam (2010a; 2010b) even states that many of the non-musical effects of music education only occur if a child enjoys these lessons. Motivation also plays an important part in school performance and is closely related to feelings of competence and ambition. If active participation in music education enhances feelings of competence and ambition, this may transfer to other domains and increase the child's motivation to persevere in other, (more) difficult tasks (Hallam, 2010a; 2010b).

Schools are free to decide what priority they give to music education (Van Hemel, 2009). Music education does not always take precedence in primary schools, partly because of the strong emphasis on arithmetic and language education (Haaij, 2012, Van Schilt-Mol, 2012). What is more, music lessons in mainstream and special primary education are often taught by class teachers. The problem, however, is that these teachers have not been specifically trained in music education and often feel insecure about their competence to teach the subject or a particular area of music (Hallam \& al., 2009). The question is whether specialist music teachers could fulfil this role in special primary education. Music teachers, after all, have the subject knowledge and skills required to provide music education. Although specialist music teachers have been thoroughly educated on the theories and methods of teaching music, SME teachers have additional knowledge about the development of children with learning difficulties and behavioural problems. They have also developed a basic attitude which is characterized by responsiveness, the ability to provide a safe (learning) environment, and class management. It is this attitude which enables the SME teacher to tailor his music lessons seamlessly to the social, cognitive and emotional abilities of the child. It is therefore preferable to have these music lessons taught by SME teachers.

SME teachers are capable of stimulating skills which are important for a child's development through musical activities. Apart from discovering and increasing their 
musical repertoire, children are encouraged to listen to each other, for example, to make choices and remember them. Children seem to be unaware or hardly aware of the fact that they are learning. This unconscious or implicit learning is the opposite of explicit learning, whereby the child is told before or during the learning process what it is expected to learn. Reber, Gitelman, Parrish \& Mesulam (2003) demonstrated that activity in subcortical areas, including the basal ganglia, supports the implicit component and the medial temporal cortex supports the explicit component. Children acquire skills through a mixture of implicit and explicit learning. Certain developments, such as the development of numeracy, do not occur automatically in most children. Teachers offer a structured approach and explicitly target (sub) skills. Music education allows children to learn while playing, in a more implicit way. Paying attention during play to skills such as making choices, expressing emotions, memorising and working together, can boost explicit learning and the acquisition of these and other skills.

This study was conducted with two aims: to explore SME in more detail and with more nuance on the one hand, and on the other to explore the potential of SME for children with special educational needs. Regarding the latter aspect, our findings seem to suggest a promising influence on neurocognitive functions, self-image, and motivation. These observations offer starting points for further research into the effects of SME in practice. Findings based on this study will be tested in a followup study examining the possible effects of SME on several neurocognitive functions, using both qualitative and quantitative methods. The follow-up study may contribute to increased clarification of the effectiveness and added value of SME. 


\section{References}

Boeije, H. (2008). Analyseren in kwalitatief onderzoek. Den Haag: Boom/Lemma.

Brodsky, W., \& Sulkin, I.(2011). Handclapping songs: Aspontaneous platform for child development. Early Child Development and Care, 181(8), 1111-1136. DOI: 10.1080/03004430.2010.517837

Chobert, J., Marie, C., Francois, C., Schön, D., \& Besson, M. (2011). Enhanced passive and active processing of syllables in musician children. Journal of Cognitive Neuroscience, 23(12), 38743887. DOI: 10.1162/jocn_a_00088

Corbin, J. M., \& Strauss, A. L. (2008). Basics of qualitative research: techniques and procedures for developing grounded theory. London: Sage Publications.

Costa-Giomi, E. (2005). Effects of three years of piano instruction on children's academic achievement, school performance and self-esteem. Psychology of Music, 32(2), 139-152. DOI: 10.1176305735604041491

Flaton, A., \& Taylor, S. J. (2006). "Who Would I Be Without Danny?" Phenomenological Case Study of an Adult Sibling. Mental Retardation, 44(2), 135-144.

Foregeard, M., Winner, E., Norton, A., \& Schlaug, G. (2008). Practicing a musical instrument in childhood is associated with enhanced verbal ability and nonverbal reasoning. Plos ONE, 3(10), 1-8. DOI: 10.1371/journal.pone.0003566

Goede, R., \& De Villiers, C. (2003). The applicability of grounded theory as research methodology in studies on the use of methodologies in IS practices. In Proceedings of the 2003 annual research conference of the South African Institute of Computer Scientists and Information Technologists on Enablement through Technology (pp. 208-217). South Africa: South African Institute of Computer Scientists and Information.

Haaij, S., Hiemstra, T., \& Slob, R. (2012). Muziek telt! Over muziekeducatie in het basisonderwijs. http://www.cultuurparticipatie.nl/reports/muziek_telt!_over_muziekeducatie_in_het_ basisonderwijs.pdf

Hallam, S. (2010a). The power of music: Its impact on the intellectual, social and personal development of children and young people. In S. Hallam, \& A. Creech (Eds.), Music education in the 21st century in the United Kingdom. Achievements, analysis and aspirations (pp. 2-17). London: Institute of Education.

Hallam, S. (2010b). The power of music: Its impact on the intellectual, social and personal development of children and young people. International Journal of Music Education, 28(3), 269-289. DOI: 10.1177/0255761410370658

Hallam, S., Burnard, P., Robertson, A., Saleh, C., Davies, V., Rogers, L., \& Kokotsaki, D. (2009). Trainee music primary-school teachers' perceptions of their effectiveness in teaching music. Music Education Research, 11(2), 221-240. DOI: 10.1080/14613800902924508

Hemel, A. van (2009). Naar een deltaplan voor het muziekonderwijs. Verkenningen van de mogelijkheden van muziekonderwijs in Amsterdam. Amsterdam: DMO/Kunst en Cultuur.

Hyde, K. L., Lerch. J., Norton, A., Foregeard, M., Winner, E., Evans, A.C., \& Schlaug, G. (2009). Musical training shapes structural brain development. The Journal of Neuroscience, 29(10), 3019-3025. DOI:10.1523/JNEUROSCI.5118-08.2009 
Ho, Y. C., Cheung, M. C., \& Chan, A.S. (2003). Music training improves verbal but not visual memory: Cross-sectional and longitudinal explorations in children. Neuropsychology, 17(3), 439-450. DOI: 10.1037/0894-4105.17.3.439

Johnson, C. M., \& Memmott, J. E. (2006). Examination of relationships between participation in school music programs of differing quality and standardized test results. Journal of Research in Music Education, 54(4), 293-307.

Meadows, L., \& Morse, J. M. (2001). Constructing evidence within the qualitative project. In J. M. Morse, J. Swanson, \& A. Kuzel (Eds.), The nature of evidence in qualitative inquiry (pp. 187202).Thousand oaks, CA: Sage.

Peters, V. (2000). Kwalitan 5.0.

Reber, P.J., Gitelman, D. R., Parrish, T. B., \& Mesulam, M. M. (2003). Dissociating explicit and implicit category knowledge with fMRI. Journal of Cognitive Neuroscience, 15(4), 574-583.

Rickard, N. S., Appelman, P., James, R., Murphy, F., Gill, A., \& Bambrick, C. (2012). Orchestrating life skills: the effect of increased school-based music classes on children's social competence and self-esteem. International Journal of Music Education, 31(3), 292-309. DOI: $10.1177 / 0255761411434824$

Rutten, M., \& Stuijts, M. (2014). Muziekstragie. [Music strategy] Maastricht, Nederland: Conservatorium Maastricht.

Schellenberg, E. G. (2004). Music lessons enhance IQ. Psychological Science, 15(8), 511-514.

Schilt-Mol, T. van (2012). Muziekles op de basisschool: meer en beter? In T. IJdens, M. van Hoorn, A. van den Broek \& C. van Rensen (Eds.), Jaarboek Actieve Cultuurparticipatie 2012. Doelen, middelen, effecten (pp. 39-52). Utrecht: Fonds voor Cultuurparticipatie.

Wester, F. (1987). Strategieën voor kwalitatief onderzoek. Muiderberg: Coutinho. 
A PRELUDE TO A NEW PERSPECTIVE

3 


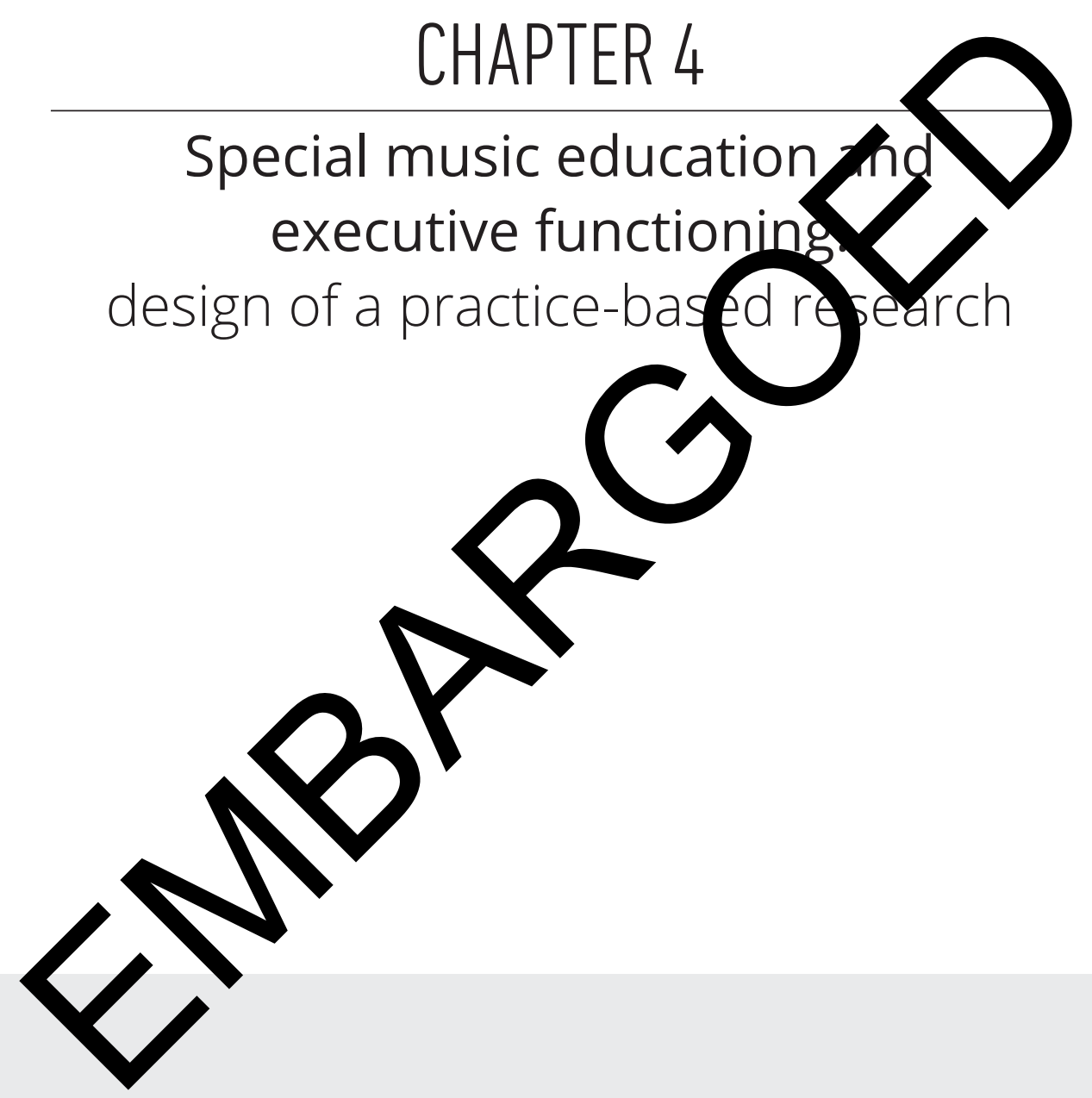

Elisabeth H. Dumont, Frans J.M. Feron, Miriam Stuijts, Elena V. Syurina, Susan van Hooren. Special music education and executive functioning: design of a practicebased research (Submitted for publication) 


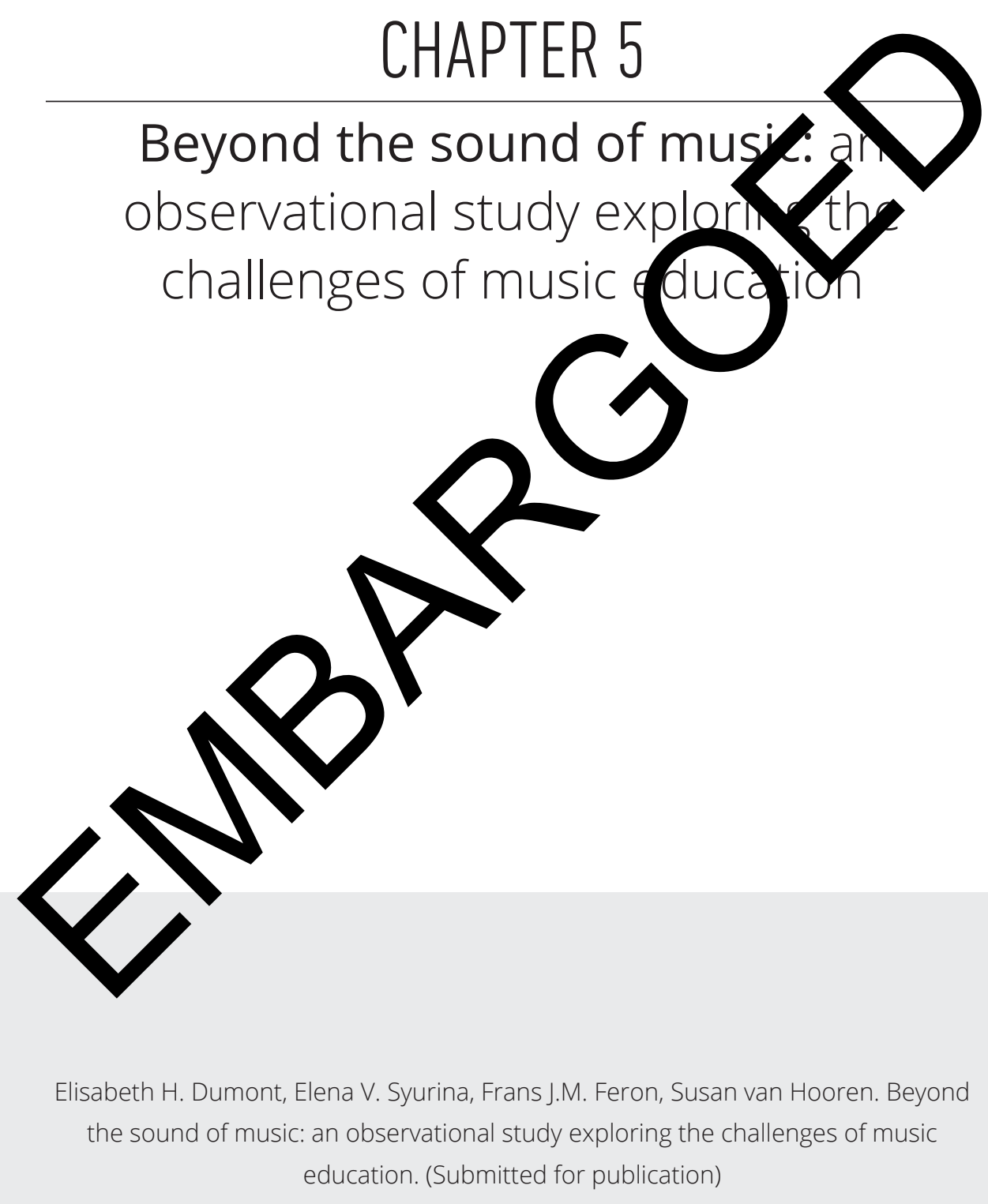




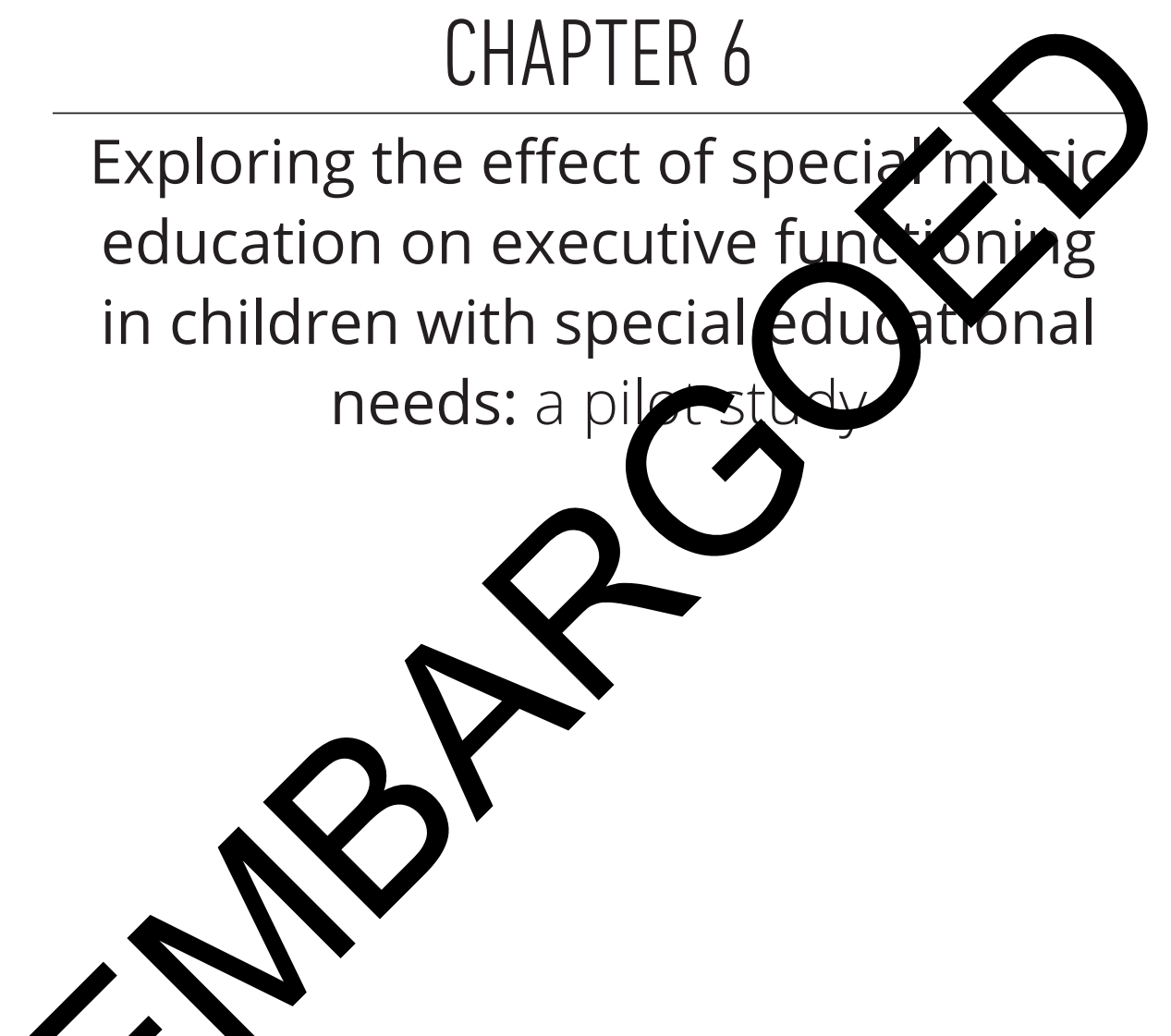

Elisabeth H. Dumont, Peter Verboon, Elena V. Syurina, Frans J.M. Feron, Susan van Hooren. The effect of special music education on executive functioning in children with special educational needs: a pilot study (Submitted for publication) 
CHAPTER 7

General discussion 
The goal of this dissertation was to investigate the potential of special music education lessons in stimulating developmental domains in children with special educational needs. The current chapter integrates the main findings of the studies within the framework of the dynamic biopsychosocial model of health, outlined in the introduction, and provides some reflections on these findings as well as the methods used. Subsequently, the implications of these findings for practice and for future research are discussed.

\section{Integration of findings into the dynamic biopsychosocial model of health}

Many interrelated factors can influence the practice as well as the research of SME, including child characteristics, teacher characteristics, the learning environment and the music, as demonstrated by the case study in the introduction. These factors are all important to consider, therefore, a holistic view of SME is required in order to enhance our understanding of relevant key concepts of SME lessons as well as the impact on the child's functioning. The dynamic biopsychosocial model, allowing for such a holistic view, was therefore used as a point of reference.

The dynamic biopsychosocial model of health (Lehman et al., 2017) can be viewed as an extended version of the biopsychosocial model (BPS) developed by Engel (1977). The BPS model is composed of three factors - biological (physical factors), psychological (cognitive, emotional and behavioural factors) and social (social contacts, social support) - and their reciprocal influence to understand health and illness. The dynamic biopsychosocial model of health extends the BPS model by including the impact of contextual aspects (broad-range culture, values) and the way these four components interact with each other as well as taking into consideration that these components can change over time (Lehman et al., 2017). In order to apply this model to the specific characteristics of SME, we adapted the content of the proposed components while leaving the framework of the model intact. 


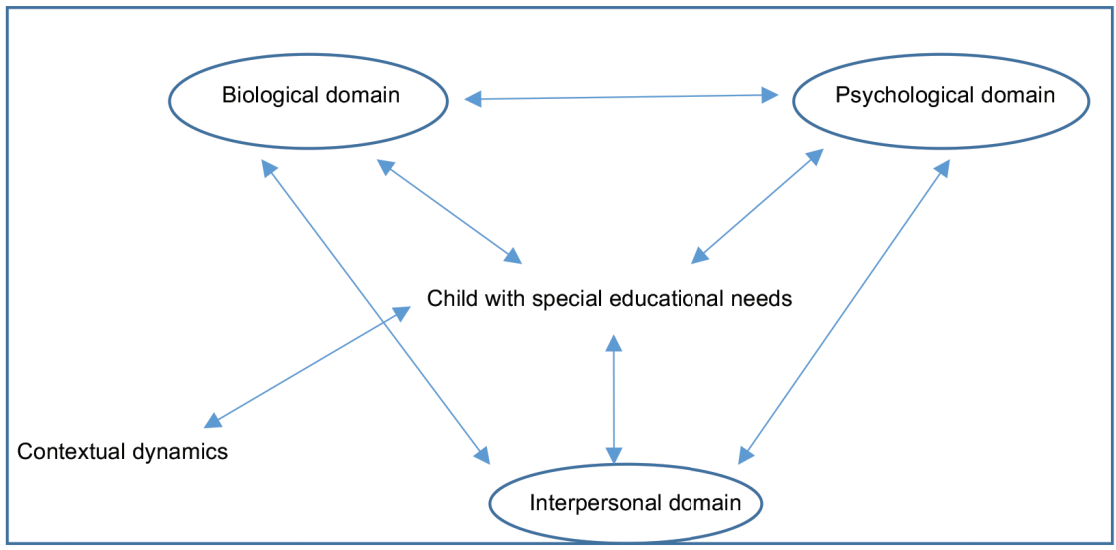

Time

Figure 1 Adapted from the dynamic biopsychosocial model (Lehman et al., 2017) showing the interaction of biological, psychological and interpersonal factors of SME lessons.

The biological domain represents the brain structures and functions involved in musical learning. Music making and musical learning are complex multimodal activities, engaging perceptual, (sensory) motor functions and association networks such as multisensory integration networks responsible for cognitive functions (Alluri \& al., 2012). The auditory modality is the primary pathway through which music is processed. Cortical auditory processing begins at core areas and progresses towards belt and parabelt areas, which correspond to primary and secondary auditory cortices. Loui, Zamm \& Schlaugh (2012) highlight the role of secondary auditory areas in sound extraction and categorization. The premotor cortex is involved in action selection, such as in the identification of rhythmic sequences (Janata \& Grafton, 2003). The motor cortices of the brain (posterior to the premotor areas) enable motor movements. Listening to metric rhythms is also shown to activate motor cortices (Grahn \& Brett, 2007). Occipital lobe regions are activated during musical imagery (Herholz, Halpern, \& Zatorre, 2012). Several networks have been suggested beyond the auditory cortices serving language, generalized auditory processing as well as music. According to the dual-stream model of language processing, a temporal-parietal-frontal network includes two streams: a dorsal stream is involved in phonological processing, while a ventral stream is involved in semantic processing (Hickok \& Poeppel, 2007). These regions are also activated in musical activities such as singing. A frontoparietal 
network, including the intraparietal sulcus and supramarginal gyrus in the parietal lobe, and the lateral and medial prefrontal cortices in the frontal lobe seem to be involved in (musical) memory and learning (Finke, Esfahani \& Ploner, 2012). Functions associated with the prefrontal cortex are attention, memory, tracking of tonal structure and musical syntax (Janata, Tillmann \& Bharucha, 2002b; Zarate \& Zatorre, 2010). Musical training (short-term and long-term) can also shape brain structure and functions. Evidence supporting these neuroplastic effects of music is derived from fMRI studies demonstrating that music training can be associated with changes in the brain, affecting both cortical and subcortical structures (Habib \& Besson, 2009; Schlaug, 2015; Herholz \& Zatorre, 2012).

The psychological domain represents a variety of processes that are involved in SME lessons, including the child's coping styles, expectations, motivation and executive functions. The term 'executive functions (EF)' is an umbrella term comprising a wide range of cognitive processes that regulate behaviour and cognition according to task demands (Diamond, 2016; Miyake \& Friedman, 2012). Despite variation amongst authors relating to conceptualization, there is agreement on complexity and interconnectivity as well as the importance of these functions for learning and development. They have also been shown to improve with practice (for a review, see Diamond, 2013). The literature review, focus group findings, the observational study as well as the pilot study in this dissertation help shed some light on these processes. Our review of the literature concerning the impact of music education and training on memory, attention and several other executive function skills as described in chapter 2 suggested potential benefits. These findings seem plausible considering the fact that active engagement in music training and education involve high demands on working memory, inhibition, attention and shifting (Hallam, Corss \& Thaut, 2011; Okada \& Slevc, 2018). Investigating whether music education and training may improve (specific) executive functions still poses some challenges. Finding a positive association between musical training and cognitive abilities could be evidence of transfer effects, but it could also reflect predispositions in cognitive abilities that influence who takes music lessons (Elpus, 2013). Another challenge in interpreting the literature is that any complex task focusing on executive functions may not only be measuring the construct of interest properly but will also be monitoring other types of processes as well (Miyake, Friedman, Emerson, Witzki, Howerter \& Wager, 2000). Furthermore, differences in conceptualization of music training and education as well as the methodology used, contribute to the difficulty in interpretation. 
Although, there has been recent developments in this research field since the literature review was published, therefore, new studies have been identified. One study found positive results of music training on concentration abilities (Barbaroux, Dittinger \& Besson, 2019). Other studies found that long-term experience in music is associated with enhanced working memory (D'souza, Moradzadeh \& Wiseheart, 2018) and improved self-control (Aleman \& al., 2017). Another study used both fMRI and neuropsychological tasks to evaluate the effect of music training on executive functioning. The authors found that children undergoing two years of music training, compared with children following sport training or without music training, showed stronger neural activation during a cognitive inhibition task in regions involved in response inhibition, despite no differences in performance on behavioural measures of executive function (Sachs, Kaplan, Der Sarkissian \& Habibi, 2017). Collaboratively, above-mentioned findings seem suggestive of some beneficial effects.

Focus group respondents in the study of this dissertation, presented in chapter 3, saw the added value of music lessons reflected in the motivation and the behaviour of a child. They also mentioned that in music lessons, they had observed children being capable of doing things they found (too) difficult before (in non-musical situations), without specifically practicing these, i.e. skills related to executive functioning. While our literature review presented mixed findings, respondents clearly underlined the versatility of music as a means to achieve cognitive goals. Observations of music lessons offered in special primary and regular primary schools in the Netherlands suggested during SME lessons, children seemed to have clear expectations of the activities they were supposed to complete and anticipated what was going to happen. Musical activities were arranged according to the child's level of ability. When noticing that a child was struggling and/or observing small changes in the child's (musical) behaviour, activities were adjusted in order to keep the child motivated and focused.

Observations, presented in chapter 5, also indicated potential benefits for children following SME lessons on the domain of self-expression as well as executive functioning. Observations of SME lessons revealed that musical activities were often repeated, thereby potentially stimulating the child's working memory. Musical activities were also expanded and/or varied, subsequently possibly stimulating cognitive flexibility. Chapter 6 described the pilot study that was designed to test the hypothesis of a potential influence of SME on executive functioning in children with special educational needs using a quasi-experimental design. Twenty-six children following 
SME lessons received weekly SME music lessons as part of the school curriculum, whereas thirty-four children in the non-SME group received their usual curriculumbased music lessons at school. Three domains of executive functions were evaluated: cognitive flexibility, working memory and attention. We decided to focus on these domains as studies have shown that sustained attention, working memory as well as shifting and planning develop considerably in the selected age group (Best, Miller \& Jones, 2009). The quasi-experimental study, however, did not show any statistically significant difference between the children following SME lessons and the children following regular music lessons with respect to development of executive functioning. Despite the absence of significant results, the pilot study showed that it was feasible to set up a longitudinal study to explore the potential of SME and provided insight into specific challenges.

The interpersonal domain represents interactions between the SME teacher, the individual child(ren) and the music. The results of two sub studies, i.e. the focus group study presented in chapter 3 and the observational study presented in chapter 5, provided some insight into the role of the SME teacher in establishing positive teacherchild relationships in the SME lessons. The importance of an SME teacher having knowledge and skills in the field of special education, teaching skills and solid musical competencies was highlighted by both SME students and teachers. Specifically, they pointed to the importance of the SME teacher being able to (1) choose musical activities and teaching methods that take into consideration the different learning styles and individual differences between children, (2) employvarying activities to create possibilities for children to experience success, (3) reward a child's (non) musical growth rather than achievement and (4) being responsive, sensitive, flexible and supportive. In accordance with the above-mentioned findings from the focus group study, observations of music lessons offered in special primary and regular primary schools in the Netherlands revealed that SME teachers had (1) thorough performance skills on instruments as well as aural, vocal skills which could be seen in his/her ability to play accompaniment and to improvise on the children's (non)musical responses, (2) a broader understanding about child development which could be observed in the teacher reading and responding to the signals of the children with understanding and sensitivity and (3) knowledge about didactics in general, but also, the ability to teach children with behavioural and/ or learning requirements by adapting activities to meet (individual) children's needs and strengths. Moreover, the teacher showing flexibility in meeting the general music aims posed by the child and constant awareness of how children experience the lesson. 
The two studies also indicated that the child and the SME teacher interact with the music itself. The SME teacher musically interacts with the child(ren) while, for example, singing, playing an instrument or using appropriate musical materials. Children explore (independently or in pairs or groups) the sounds instruments make, duration, melodies, thereby exploring and creating their own musical experiences.

Contextual factors comprise two components: elements inside (class dynamics, setting, musical material) and outside (friends, family relationships) the SME lessons. Observations presented in chapter 5 revealed two important elements inside the SME lessons influencing the way SME teachers translated their ideas into action; the physical classroom and the musical equipment. Schools providing SME lessons had a separate music room in their building, offering plenty of opportunities to move around and to interact in pairs/groups. Observations also revealed that schools providing SME lessons had extensive musical equipment. Besides accompanying activities with music, these resources allowed SME teachers to let children often work in pairs, encouraging social interaction (interpersonal domain), aural awareness (biological domain) as well as encouraging them to use problem solving skills (psychological domain).

As observed in the model, development and changes in one domain cannot be understood in isolation, it must be analysed holistically, by looking at the interaction of the other domains too. This becomes clear when regarding, for example, the choice of instrument in an SME lesson from a child's perspective. This choice can be motivated by whether or not the sound of the instrument is too sharp (biological), depending on the availability (context), whether the child feels confident with an instrument (psychological) or the particular activities the teacher selected for the lesson (interpersonal). Another example relates to a child's learning difficulties. Problems in executive functioning (psychological) can cause problems in getting along with other children in the class (interpersonal domain) and/or might result in emotional difficulties when struggling to find social support (contextual factors), which can impact a child's motivation (psychological domain). Meeting the child's educational needs is another example of how domains can be interrelated. As children receive SME lessons only once a week, the exchange of information about the group with other disciplines (e.g. psychologist, social work) as well as the class teacher is important in understanding the (changing) needs of the child and creating or adapting a tailored approach; this may be visible in a change in the teacher's attitude or instructions (interpersonal), the position of the child in relation to others/the teacher during the lesson (context) and whether or 
not the child feels challenged by an activity (psychological). Based on the information exchanged, SME should be provided in an adaptive and flexible way to meet the child's (changing) needs.

\section{Towards integrative educational practices}

When attempting to interpret and integrate above mentioned findings in the context of education and educational practices, it is important to remember the unique features of SME.

Special music education (SME) is an educational perspective, in which the child's musical development is stimulated and at the same time musical involvement is used to encourage cognitive, emotional and motor developmental and learning goals. This may raise questions about how SME attempts to meet specific needs of individual children in a classroom. In order to explain this, we make the distinction between regular school subjects and SME. Reading, writing and/or learning mathematics are subjects that are taught either implicitly or explicitly, requiring several complex accomplishments, i.e. forming a relationship between sounds and letters or connecting numerals to the quantities with dichotomous outcomes. How does SME differ from these subjects? In contrast to learning to read or learning mathematics, SME lessons offer more authentic learning experiences. Authentic learning experiences can be defined as experiences that allow the learner to share and experience learning in a context that is personally relevant (Herrington, Reeves \& Oliver, 2014). Although in SME lessons, the musical content is considered and provided by the SME teacher, the children apply the musical learning content in different ways and integrate these experiences in their own personal learning. They learn to cope with different forms of musical behaviour, i.e. sound (melody, dynamics), form (improvisation, couplet), and meaning (function, emotional meaning) through singing, playing, moving, or notating music, by listening and talking about music (reflecting), and by composing music. Within these contexts, the children may take different roles: for example, they may be a singer, a dancer, a part of the ensemble or a solo player. These roles allow children to focus on collaboration, being flexible with the application of their ideas with no fixed outcome in mind, to craft new, creative salutation and to guide their own learning. The use of real musical instruments is appealing and lifelike to them. By setting up or imitating the formation of a band / an ensemble / choir, children are 
able to master a deeper understanding of the musical material at hand and to make meaning of music and the musical material in ways that are personally relevant.

It was expected that SME lessons could positively influence a child's executive functions. Despite the fact that our quantitative study did not show statistically significant evidence for a beneficial effect of SME on executive functions, the results of the qualitative studies certainly provide a basis for this hypothesis. The results of different sub-studies showed that SME is promising and that it is worthwhile to examine this further. Firstly, SME teachers and students provided concrete examples which pointed to a positive influence of SME lessons on executive functioning. This became evident through the focus group study, in which positive improvements on skills related to attention and memory were mentioned by respondents. Secondly, the observational study revealed a certain amount of repetition and variation in musical activities during SME lessons, as well as their interconnection and the extension of activities by adding a layer of complexity to the activity once it had been mastered. These repetitions and variations could potentially stimulate children's developing working memory and flexibility. Thirdly, several studies have suggested potential benefits of music interventions on executive function skills, as was shown in the literature review. It was possible to test the impact of SME on a larger scale, as demonstrated in the pilot study. Although the results did not reveal significant differences in executive functioning across time when comparing children who followed SME lessons to children following regular music lessons, this study shows that it is feasible to explore the impact of SME in the complex context of school in more detail. The pilot provides new areas to investigate and offers a possible opportunity to explore these areas further within this specific context and population.

\section{Methodological reflections}

This paragraph will discuss several conceptual and practical aspects related to the quantitative and qualitative studies and provide some insights into the strengths and limitations of this research.

This research was exploratory in nature; therefore, a range of research methods were used to determine the research area worth pursuing and to gain a better understanding of the potential of SME when it is provided in daily practice. A literature 
review was conducted to capture a broad overview of the effects of music on child development. Focus groups and observations enabled us to identify important elements of SME as well as its potential. The results of these qualitative studies were used as input for the quasi-experimental study, which was conducted to determine the potential effect of SME. As (special) music education in (special) primary education constitutes a complex reality, we took educational practices as a starting point for increased ecological validity. The design used did not provide for full control of confounding variables, thereby lowering internal validity. However, conducting an experimental study in this naturalistic setting was not feasible due to the impossibility to randomly allocate children and the creation of an artificial situation that was no longer representative of reality.

With regard to conceptualization, the dynamic biopsychosocial model was useful as a way of viewing SME from an integral perspective. Although not a representation of the reality itself, the model helped us to infer how reality might work, allowing for the recognition of the reciprocal influences of biological, psychological and interpersonal factors over time. However, this model offered a very broad framework, not providing specific information regarding specific factors of influence. Therefore, other models have been considered, including neuropsychological (Luria, 1973) and didactic (Hiim \& Hippe, 1998; Van Gelder, Peters, Oudkerk Pool \& Sixma, 1973) models. While partially useful, these models turned out to be too specific and for some didactic models, little empirical evidence is available.

Another strength of the study is that the potential impact of SME was made explicit from a practice-based perspective; respondents of focus groups were asked to identify domains of outcomes they considered important in noticing the effects of SME. When analysing all domains potentially influenced, we selected one, i.e. executive functioning, and we pursued our research accordingly. It should however be noted that we included SME teachers only and not, for example, their class teacher colleague, who also have a clear perception of children's capabilities and needs. More diverse groups are needed to confirm our findings as well as to capture the potential domains of impact more fully. With regard to the execution of the research study, there are a number of aspects that need to be considered. We included both regular primary and special primary schools to better match the educational context of the Netherlands as, according to the national Appropriate Education Policy, both types of schools play an important role in meeting a range of educational and/or behavioural needs of a child. The number of schools 
included was, however, small. Although eighty-eight (special) primary schools in three provinces in the Netherlands, offering music as a separate subject in their curricula, were approached, the non-response rate was substantial and only five schools from a small area were included in the study.

The sample of children studied was also small. However, the purpose of this research was to examine the process of SME in depth from various perspectives, providing greater insight into its potential, insight on the feasibility of the current approach and variables to be included in a larger study to follow instead of presenting conclusive evidence.

Pragmatically, neuropsychological paper-and-pencil tasks were used to establish a profile of each child's strengths and weaknesses in the three executive functioning domains. Although providing a relatively objective way of collecting information about the child's cognitive functioning, it should be considered whether this form of neuropsychological evaluation was the most suitable approach to use to explore the impact of SME. One challenge lies in the fact that there is a great difference between performance on neuropsychological tasks and on naturalistic tasks encountered in real life (Chan, Shum, Toulopoulou \& Chen, 2008).

Apart from determining (a) suitable way(s) of measuring executive functions, the question arises which other domains could be of particular interest. As it is evident that executive functioning is not the only domain that could be considered, qualitative research could provide additional or new insights into the (search for) potential domains which can guide further exploration of SME.

The observations of music lessons were conducted by third-year students from the music education department. Unfortunately, there was no mechanism to disguise what type of school and educational background of the teacher they were observing, so there may have been an increased risk of reporting bias. Also, they might not have observed all important elements of a teachers' actions due to the fact that they were still in training. However, we decided that including observers who had thorough musical knowledge as well as context knowledge represented the most appropriate option to gather useful information on music education in the (special) primary school context. 


\section{Recommendations for further research}

In the present research, we evaluated the impact of SME lessons by analysing whether these lessons led to improved performance on several neuropsychological tasks. However, the impact could also be determined in different ways, for example by asking (parents and teachers of) children who currently follow SME lessons and/or children/ adults who participated in these lessons to describe and evaluate their experiences as well as (expected) outcomes. When asked about potential effects, respondents of focus groups also mentioned effects on social interaction and self-perception. Therefore, other ways to explore the impact of SME might be examining quality of life outcomes of children or an in-depth exploration of child-child interactions during (SME) lessons in school as well as in other situations outside the classroom. Process evaluation could provide another way of evaluating SME. Instead of focusing on outcomes of SME, this approach offers an opportunity to explore the expectations of participants and SME teachers, the delivery, the organization and the scope of SME, providing a base for making adjustments and resolving unforeseen problems in its implementation (Rubin, Pronovost \& Diette, 2001).

Although, it is not the essence of the present research, the (long-term) effects of SME on the developing brain remains an important topic in the approach and understanding of its impact. The outcomes of music training and education on development result from the interplay of psychological factors (personality traits, coping strategies), social factors (interactions, social class) within a particular context. In order to understand how these factors interact and potentially influence outcomes, we cannot exclude the biological factor as it also affects behaviour. The relationship between social, psychological and biological factors is interchangeable, for example, brain circuits are influenced by psychological and social factors. Functional neuroimaging techniques offer the possibility to explore and identify SME-related changes. Although correlations between brain activity and behaviour does not prove a causal link (Beck, Locke, Savine, Jimura \& Braver, 2010), an observed link can guide researchers as they further explore the impact (of components) of SME. Studies that include the simultaneous measurement of fMRI and neuropsychological tasks may improve the possibility of deducting causal inferences as well as a more holistic view of the impact of SME.

Considering SME, we explored it from a holistic approach. Although several key factors within SME were identified, in the next step, we need to identify more specific (critical) factors, which can be used to further investigate the impact on the child, on 
behavioural, cognitive and brain level. Adopting a realism paradigm as a conceptual framework, as opposed to a more fragmented vision, could be useful as a guideline for further exploring the concept of SME in a valid and appropriate manner. The impact of SME on behaviour and development of the child is difficult to study in a controlled environment as we cannot control all potential factors of influence. Furthermore, outcomes of one study are difficult to generalize to a wide and heterogeneous group of children regardless of if they have some similarities. Therefore, further research on the impact of SME should focus on disentangling what is applicable for different children in various circumstances. Moreover, findings provide suggestive insight into potentially important mechanisms and context variables that lead to outcomes of interest. This implies that not all influencing variables can and need to be controlled successfully since it may not be possible to control them independently from each other or their influence may not be detected yet. The building of (new) knowledge of SME should be viewed as cumulative; further studies build on one other, exploring various aspects of SME and each adding a new dimension to its understanding.

\section{Recommendations for practice}

An issue which merits attention is the explicit use of tacit knowledge of SME. We noticed that especially the older participants in the focus group seemed to provide the (non) musical content as an integral part of learning and practicing. They were, with regard to the beneficial effects of SME, sometimes unaware of the full range of expertise employed and their knowledge seemed more intuitive (tacit) and practice based. Their statements were in contrast to statements from SME students and younger SME teachers, who clearly point to conscious adaptation of teaching methodology and musical activities to the needs of the child. Also, observations suggested that SME teachers seemed to have an intuitive approach in the selection and use of musical instruments to engage the children. Uncovering and transmitting this tacit knowledge of SME in education is of great importance since it may result in mutual learning, valuable resources, reflection and the creation of new knowledge. Being able to elicit tacit knowledge from SME professionals or even older, more advanced students. This could help younger students to build awareness and competence as they develop their skills and knowledge not only in theory but also in fieldwork and the sharing of good practices. Tutorial groups, shared conversations and/or observations providing context that gives meaning to choices and actions is also beneficial. This 
is because it allows younger students to recognize the tacit knowledge behind the accomplishments during the SME lessons as well as to capture best practices.

In this thesis, we explored the association between SME and executive functions. These functions, their role in learning and the ways they potentially could be influenced by SME are not explicitly mentioned in the textbook of the educational program yet. While the current textbook is an important and valuable synthesis of the theoretical knowledge as well as the practical applications in SME, it could benefit from the results in this dissertation. Considering this aspect may result in updating teaching resources, which is essential to the perseveration of education.

\section{Final conclusion}

In this dissertation, we explored the potential influence of SME on executive functioning in children with special educational needs. Observations of SME lessons revealed repetition, expansion and variation in musical activities as important elements potentially contributing to stimulating executive functions in children following these lessons. From the focus group discussions, both SME teachers and students mentioned also the effects on the domain of executive functioning among others. In the quasi-experimental pilot study, we derived certain key principles, in particular about the feasibility of this design in a complex school context, the potential efficacy of SME on executive functioning as well as on methodological challenges encountered when carrying out the research, providing a base for further research. More research is needed to replicate and expand the evidence-based knowledge on SME as well as on the potential effects on different aspects of child development.

Although there are challenges across the provision of special music education, it is important to monitor/consider its ongoing access for children with special educational needs. Especially, when considering the complexity of learning and behavioural problems in special primary schools. Also, investment in teacher qualifications and continued development in methodology of special music education for these children are essential for further theory development of SME and its use in practice. 


\section{References}

Alemán, X., Duryea, S., Guerra, N., McEwan, P.J., Muñoz, R., Stampini, M., \& Williamson, A. (2017). The Effects of Musical Training on Child Development: a Randomized Trial of El Sistema in Venezuela. Prevention Science, 18(7), 865-878. DOI: 10.1007/s11121-016-0727-3

Alluri, V., Toiviainen, P., Jääskeläinen, I. P., Glerean, E., Sams, M., \& Brattico, E. (2012). Large-scale brain networks emerge from dynamic processing of musical timbre, key and rhythm. Neuroimage, 59(4), 3677-3689. DOI:10.1016/j.neuroimage.2011.11.019

Barbaroux, M., Dittinger, E., \& Besson, M. (2019). Music training with Démos program positively influences cognitive functions in children from low socio-economic backgrounds. PloS one, 14(5), e0216874. DOI: 10.1371/journal.pone.0216874

Beck, S. M., Locke, H. S., Savine, A. C., Jimura, K., \& Braver, T. S. (2010). Primary and secondary rewards differentially modulate neural activity dynamics during working memory. PloS one, 5(2), e9251. DOI: 10.1371/journal.pone.0009251

Best, J. R., Miller, P. H., \& Jones, L. L. (2009). Executive functions after age 5: Changes and correlates. Developmental review, 29(3), 180-200. DOI: 10.1016/j.dr.2009.05.002

Chan, R. C., Shum, D., Toulopoulou, T., \& Chen, E. Y. (2008). Assessment of executive functions: Review of instruments and identification of critical issues. Archives of clinical neuropsychology, 23(2), 201-216. DOI:10.1016/j.acn.2007.08.010

Diamond, A. (2013). Executive Functions. Annual Review of Psychology, 64, 135-168. DOI: 10.1146/ annurev-psych-113011-143750

Diamond, A. (2016). Why improving and assessing executive functions early in life is critical. In J. A. Griffin, P. McCardle, \& L. S. Freund (Eds.), Executive function in preschool-age children: Integrating measurement, neurodevelopment, and translational research. Washington, DC: American Psychological Association.

D'Souza, A. A., Moradzadeh, L., \& Wiseheart, M. (2018). Musical training, bilingualism, and executive function: working memory and inhibitory control. Cognitive research: principles and implications, 3(1), 11. DOI:10.1186/s41235-018-0095-6

Elpus, K. (2013). Is it the music or is it selection bias? A nationwide analysis of music and nonmusic students' SAT scores. Journal of Research in Music Education, 61(2), 175-194. DOI: $10.1177 / 0022429413485601$

Engel, G. L. (1977). The need for a new medical model: A challenge for biomedicine. Science, 196, 129-136. DOI: 10.1126/science.847460

Finke, C., Esfahani, N. E., \& Ploner, C. J. (2012). Preservation of musical memory in an amnesic professional cellist. Current Biology, 22(15), R591-R592.

Grahn, J. A., \& Brett, M. (2007). Rhythm and Beat Perception in Motor Areas of the Brain. Journal of Cognitive Neuroscience, 19(5), 893-906. DOI: 10.1162/jocn.2007.19.5.893

Habib, M., \& Besson, M. (2009). What do music training and musical experience teach us about brain plasticity?. Music Perception: An Interdisciplinary Journal, 26(3), 279-285. DOI:10.1525/ MP.2009.26.3.279 
Hallam, S., Cross, I., \& Thaut, M. (Eds.). (2011). Oxford handbook of music psychology. Oxford University Press.

Herholz, S. C., \& Zatorre, R. J. (2012). Musical training as a framework for brain plasticity: behavior, function, and structure. Neuron, 76(3), 486-502. doi.org/10.1016/j.neuron.2012.10.011

Herholz, S. C., Halpern, A. R., \& Zatorre, R. J. (2012). Neuronal correlates of perception, imagery, and memory for familiar tunes. Journal of cognitive neuroscience, 24(6), 1382-1397. DOI:10.1162/ jocn_a_00216

Herrington, J., Reeves, T. C., \& Oliver, R. (2014). Authentic learning environments. In Handbook of research on educational communications and technology (pp. 401-412). New York: Springer.

Hickok, G., \& Poeppel, D. (2007). The cortical organization of speech processing. Nature Reviews. Neuroscience, 8(5), 393-402. DOI: 10.1038/nrn2113

Hiim, H., \& Hippe, E. (1998). Laering gjennom opplevelse, forståelse og handling: En studiebok i didaktikk (2 ed.). Oslo: Universitetsforlaget

Janata, P., Tillmann, B., \& Bharucha, J. J. (2002b). Listening to polyphonic music recruits domaingeneral attention and working memory circuits. Cognitve, Affective \& Behavorial Neuroscience, 2(2), 121-140.

Janata, P., \& Grafton, S. T. (2003). Swinging in the brain: shared neural substrates for behaviors related to sequencing and music. Nature neuroscience, 6(7), 682.

Lehman, B. J., David, D. M., \& Gruber, J. A. (2017). Rethinking the biopsychosocial model of health: Understanding health as a dynamic system. Social and personality psychology compass, 11(8), e12328. DOI: $10.1111 /$ spc3.12328

Loui, P., Zamm, A., \& Schlaug, G. (2012). Enhanced functional networks in absolute pitch. Neurolmage, 63(2), 632-640. DOI: 10.1016/j.neuroimage.2012.07.030

Luria, A.R. (1973). The working brain. New York: Basic Books.

Miyake, A., \& Friedman, N. P. (2012). The Nature and Organization of Individual Differences in Executive Functions: Four General Conclusions. Current Directions in Psychological Science, 21(1), 8-14. DOI: 10.1177/0963721411429458

Miyake, A., Friedman, N. P., Emerson, M. J., Witzki, A. H., Howerter, A., \& Wager, T. D. (2000). The unity and diversity of executive functions and their contributions to complex "frontal lobe" tasks: A latent variable analysis. Cognitive psychology, 41(1), 49-100. DOI:10.1006/cogp.1999.073

Okada, B. M., \& Slevc, L. R. (2018). Musical training: Contributions to executive function. In M. Bunting, J. Novick, M. Dougherty, \& R. W. Engle (Eds.), An integrative approach to cognitive and working memory training: Perspectives from psychology, neuroscience, and human development. New York: Oxford University Press.

Rubin, H. R., Pronovost, P., \& Diette, G. B. (2001). The advantages and disadvantages of processbased measures of health care quality. International Journal for Quality in Health Care, 13(6), 469-474.

Sachs, M., Kaplan, J., Der Sarkissian, A., \& Habibi, A. (2017). Increased engagement of the cognitive control network associated with music training in children during an fMRI Stroop task. PloS one, 12(10), e0187254. DOI: 10.1371/journal.pone.0187254 
Schlaug, G. (2015). Musicians and music making as a model for the study of brain plasticity. In Progress in brain research (Vol. 217, pp. 37-55). Elsevier. DOI: 10.1016/bs.pbr.2014.11.020

Van Gelder, L., Peters, J., Oudkerk Pool, T., \& Sixma, J. (1973). Didactische Analyse Werk-en Studieboek. Groningen: Wolters-Noordhoff

Vaughn, S., Schumm, J. S., \& Sinagub, J. M. (1996). Focus group interviews in education and psychology. Thousand Oaks, CA: Sage.

Zarate, J. M., Wood, S., \& Zatorre, R. J. (2010). Neural networks involved in voluntary and involuntary vocal pitch regulation in experienced singers. Neuropsychologia, 48(2), 607-618. 


\section{Summary}

Samenvatting

\section{Valorisatie \\ Dankwoord}

Curriculum Vitae

Publications 


\section{SUMMARY}

Special music education is an educational perspective, in which the child's musical development is stimulated and at the same time musical participation is used to encourage cognitive, emotional and motor developmental and learning goals (Rutten \& Stuijts, 2014). Teaching methodology, musical activities and participation involvement are adapted to the educational needs of the individual child as well as the class. Although experiences of special music educators and special music education students as well as research findings on the wider potential of music seem to suggest that special music education may be beneficial to children with special educational needs, scientific evidence in this field is absent.

The goal of this dissertation was to provide insight into the potential of special music education in addressing developmental domains in children with special educational needs. It aimed to explore the concept of special music education and its potential in stimulating development in children following these lessons from a practice-based perspective. Such insights will contribute to a better understanding of its significance within the special educational context.

In order to reach this aim, this study used a mixed method design. The first phase of the research involved a literature review focusing on the effect of music interventions on the development of children. It also included focus groups in order to explore the concept of special music education and its possible added value for children in special primary education. The second phase of the research consisted of a quasiexperimental study that explored the impact of special music education in children with special educational needs in five Dutch (special) primary schools.

The following questions were formulated as initial starting points for the research:

1. What are the effects of music training and education on learning and development of children, described in the literature?

2. What are methods and lines of reasoning used in special music education and what potential may it hold for children with special educational needs?

3. How is music education offered in (special) primary schools in the Netherlands presently and what factors influence this provision?

4. What is the potential of special music education on executive functioning in children with special educational needs, compared to regular music education? 
Answers to these research questions are provided in the chapters 2 to 6 of this thesis

Chapter 1 provides the introduction to this dissertation. It describes the role of a specific type of music education, namely special music education, and its potential applicability for children with special educational needs. First, the characteristics of children with special educational needs and the Dutch (special) primary education system are explained. Secondly, the wider potential of music in education and the role of special music education are discussed. Thirdly, a description of the dynamic biopsychosocial model of health is provided, containing a number of factors which are considered to be relevant in researching special music education lessons and its impact on the child's functioning. Finally, the aim and research questions are outlined.

In chapter 2, a literature review is outlined on the effect of musical interventions across various domains of development of primary school-aged children. Four electronic databases were searched from January 2010 to June 2016 using music, music instruction, music education, music lesson, music training, development, child, student, and pupil as keywords for the search. Two reviewers independently evaluated the studies to determine whether they met the stated inclusion criteria. Studies were compared to study design, methodological quality, intervention components, outcome variables, and efficacy. Results suggested a positive influence of music interventions on specific motor skills. Research also suggested a positive influence of music on academic performance, although precise conclusions are hard to form. No clear conclusions can be drawn about the language, social and cognitive domains due to the wide heterogeneity of study designs and findings. Overall, results of reviewed studies seemed to suggest some beneficial effects of music interventions on child development, including executive functioning, but still remained inconclusive partly due to differences in conceptualization of music training and education as well as the methodology used.

In chapter 3, the concept of special music education is explored in more detail, as well as the potential which special music education may hold for children with special educational needs. Two focus groups were conducted with special music educators and special music education students, who participated in discussions about views, attitudes and experiences regarding special music education. Analyses showed that within special music education, three core factors can be distinguished: (1) music, (2) personal characteristics of the special music teacher and (3) the child. In contextualizing special music education, practical requirements and consultation with other disciplines also proved to be relevant. Results seemed to suggest a promising perspective for a positive influence of special 
music education on the neurocognitive functions, self-image and motivation of children. Chapter 4 presents the study design in order to examine the potential effects of special music education lessons on executive functioning in children aged six to nine attending (special) primary education. This chapter describes the use of a mixed method design, in which both qualitative and quantitative research methods are used to explore the potential of special music education within the complexity of the school context. Theoretical and practical implications of the proposed design are discussed.

In chapter 5, the current provision of music education offered in (special) primary schools in the Netherlands is explored as well as factors influencing this provision. This qualitative study employed observational research methods. A total of 16 music lessons were observed at five different schools over the course of ten months. Of the five participating schools, two were primaryschools and threewerespecial primaryschools. An observational schema based on the outcomes of the focus groups was used in order to structure the observations. Results revealed similarities between the schools in terms of (1) the active participation of the child, (2) the duration of musical activities and (3) (non-)verbal communication and non-verbal encouragement from the teacher. Differences between schools were observed in (1) the music equipment and space available to teach music, (2) the child's enjoyment, expectations and own contribution, (3) the musical domains considered, the amount of variation and repetition of musical activities as well as how activities were connected and expanded, (4) teacher behaviour and musical abilities and (5) the way teachers organized instruction and employed teaching methods. A number of elements of good practice were derived from the observations i.e. (1) the teacher having thorough performance skills on instruments as well as oral, vocal skills as could be seen in his/her ability to improvise and to accompany the children playing instruments or their singing, (2) the teacher having a deep understanding about child development as could be observed in the teacher observing, signalling and responding to the signals of the children with understanding and sensitivity and (3) the teacher having knowledge about didactics in general as well as the teaching of children with behavioural and/or learning needs as could be seen in the teacher adapting activities to meet (individual) children's needs and strengths as well as general musical aims. All elements were applicable to the teaching of special music education lessons in the special primary schools. Observations also indicated potential benefits for children following special music education lessons on the domain of self-expression as well as executive functioning. 
Chapter 6 describes a pilot study, designed to explore the potential influence of special music education on executive functioning in children with special educational needs using a quasi-experimental design. Data on executive functioning was collected from 60 children between the ages of six and nine years at five different schools for regular and special primary education four times during one school year. Twenty-six children following special music education lessons received weekly special music education lessons as part of the school curriculum, whereas 34 children in the regular music education-group received their usual curriculum-based music lessons at school. Three domains of executive functions were evaluated: cognitive flexibility, working memory and attention. Multilevel analyses revealed different patterns of executive functioning across time for regular primary schools and special primary schools. However, results did not show statistically significant differences between the children following special music education lessons and the children following regular music lessons with respect to executive functioning. Despite the absence of significant results, the pilot study showed that was feasible to set up a longitudinal study to explore the potential of special music education and provided insight into specific challenges, which could serve as a basis for further research.

Chapter 7 comprises the general discussion of this dissertation. First, the main research findings are discussed and integrated in the dynamic biopsychosocial model. Topics evaluated include the biological, psychological, interpersonal and contextual factors as well as their interaction relevant to understanding the potential of special music education. Subsequently, these findings are placed into educational practice. Methodological strengths and limitations are considered, in particular the conceptual and practical aspects related to the qualitative and quantitative studies, providing a broader perspective on the research of special music education. Finally, recommendations for future research and for practice are offered.

This dissertation helps show that special music education has the potential to stimulate children with special educational helps to their non-musical development. Many factors contribute to children's learning and development and may play a part in determining how (musical) activities in special music education lessons should be shaped to ensure that the needs of the individual child as well as the group are addressed. A personalized approach that aims at giving the child the (musical) building blocks needed to grow or to overcome his/her learning and/or behavioural difficulties, is essential. 


\section{References}

Rutten, M., \& Stuijts, M. (2014). Muziekstragie [Music Strategy]. Maastricht, Nederland: Conservatorium Maastricht. 


\section{SAMENVATTING}

Orthopedagogische muziekbeoefening is een manier van handelen binnen een muziekeducatieve dan wel -vormende pedagogische situatie waarin de muzikale ontwikkeling van een kind wordt gestimuleerd en tegelijkertijd muzikale participatie wordt gebruikt om te werken aan doelstellingen op sociaal-emotioneel, cognitief en/ of sensomotorisch gebied (Rutten \& Stuijts, 2014). Didactiek, muzikale activiteiten en de wijze van participatie worden aangepast aan de onderwijsbehoeften van het individuele kind en de klas als geheel. Hoewel ervaringen van zowel studenten orthopedagogische muziekbeoefening en orthopedagogisch muziekbeoefenaars suggereren dat orthopedagogische muziekbeoefening een gunstige uitwerking kan hebben op kinderen met speciale onderwijsbehoeften, ontbreekt tot nu toe wetenschappelijk bewijs hiervoor.

Het doel van deze thesis is het verkrijgen van inzicht in de potentie van orthopedagogische muziekbeoefening in het stimuleren van ontwikkelingsdomeinen van kinderen met speciale onderwijsbehoeften. De hiermee verkregen inzichten zouden kunnen bijdragen aan een beter begrip van de relevantie van orthopedagogische muziekbeoefening binnen de context van het speciaal onderwijs.

Om dit doel te bereiken is in dit onderzoek gebruik gemaakt van diverse onderzoeksmethodologieën, waarbij een praktijk-gebaseerd perspectief werd gehanteerd. De eerste fase van het onderzoek betrof een literatuurstudie gericht op de effecten van muziekonderwijs en -training op de ontwikkeling van kinderen. ook werden focusgroepinterviews gehouden om het concept van orthopedagogische muziekbeoefening te exploreren en de mogelijke meerwaarde voor kinderen binnen het speciaal basisonderwijs te verkennen. In tweede fase van het onderzoek werd een quasi-experimentele studie uitgevoerd met als doel de impact van orthopedagogische muziekbeoefening op kinderen met speciale onderwijsbehoeften in vijf scholen voor speciaal en regulier onderwijs in Nederland te bepalen.

De volgende onderzoeksvragen zijn geformuleerd:

1. Welke effecten van muziekonderwijs en -training op het leren en de ontwikkeling van kinderen worden beschreven in de literatuur?

2. Welke werkwijzen en daaraan gelieerde gedachtegangen worden toegepast binnen orthopedagogische muziekbeoefening en wat kan de mogelijke 
meerwaarde van orthopedagogische muziekbeoefening voor kinderen met speciale onderwijsbehoeften zijn?

3. Hoe wordt muziekonderwijs in het (speciaal) basisonderwijs in Nederland aangeboden en welke factoren zijn hierop van invloed?

4. Wat is het effect van orthopedagogische muziekbeoefening op het executief functioneren van kinderen met speciale onderwijsbehoeften, vergeleken met regulier muziekonderwijs?

In de hoofdstukken 2 tot en met 6 van dit proefschrift wordt antwoord gegeven op deze onderzoeksvragen.

Hoofdstuk 1 leidt het proefschrift in, wat betreft de rol van een bepaald type muziekonderwijs, namelijk orthopedagogische muziekbeoefening, en de mogelijke meerwaarde van orthopedagogische muziekbeoefening voor kinderen met speciale onderwijsbehoeften. In dit hoofdstuk wordt het speciaal basisonderwijs in Nederland beschreven en worden de kenmerken van kinderen met speciale onderwijsbehoeften besproken. Vervolgens wordt ingegaan op de meerwaarde van het vak muziek binnen het (speciaal) onderwijs waarbij meer specifiek wordt gekeken naar de rol van orthopedagogische muziekbeoefening. Verder wordt er een beschrijving van het geïntegreerde biopsychosociaal model gegeven. Dit model onderscheidt een aantal factoren die als relevant worden beschouwd bij het exploreren en onderzoeken van orthopedagogische muziekbeoefening en de mogelijke impact van orthopedagogische muziekbeoefening op het functioneren van een kind. Tot slot worden de onderzoeksvragen en het doel van dit proefschrift beschreven.

Hoofdstuk 2 beschrijft de bevindingen van een systematische review met betrekking tot de effecten van muzikale interventies op verschillende ontwikkelingsdomeinen bij kinderen in de leeftijd van 6 tot 12 jaar. De elektronische databases PubMed, PsychInfo, EMBASE en EBSCO werden doorzocht voor relevante artikelen die zijn gepubliceerd vanaf januari 2010 tot juni 2016 met behulp van relevante sleutelwoorden. Ook werd handmatig gezocht. Twee reviewers beoordeelden onafhankelijk van elkaar of studies voldeden aan gestelde inclusiecriteria. Studies werden geanalyseerd op basis van onderzoeksopzet, methodologie, type interventie, uitkomstmaten en efficiëntie. De resultaten suggereren een positieve invloed van muzikale interventies op specifieke motorische vaardigheden en academische vaardigheden, hoewel het beeld in laatstgenoemd domein minder eenduidig is. Ten aanzien van de effecten op de taal-, 
de sociale en de cognitieve ontwikkeling kunnen vanwege heterogeniteit in studie opzet en bevindingen geen eenduidige conclusies worden getrokken.

Hoofdstuk 3 beschrijft de bevindingen uit een kwalitatieve studie die als doel had inzicht te krijgen in het kader van orthopedagogische muziekbeoefening gevolgde werkwijzen en daaraan gelieerde gedachtegangen en in de mogelijke meerwaarde van orthopedagogische muziekbeoefening voor kinderen met speciale onderwijsbehoeften. Twee focusgroepen werden gevormd met orthopedagogische muziekbeoefenaars en studenten orthopedagogische muziekbeoefening, die met elkaar in discussie gingen over opvattingen, standpunten en ervaringen rondom orthopedagogische muziekbeoefening. Analyses laten zien dat er binnen orthopedagogische muziekbeoefening drie kernfactoren te onderscheiden zijn: (1) de muziek, (2) de de orthopedagogisch muziekbeoefenaar en (3) het kind. Daarnaast blijken zowel de rol van de setting als ook overleg met andere disciplines relevant. Resultaten wijzen erop dat orthopedagogische muziekbeoefening als een veelbelovend perspectief wordt gezien dat een positieve invloed kan hebben op neurocognitieve functies, zelfbeeld en motivatie van het kind.

In hoofdstuk 4 wordt het onderzoeksdesign om de mogelijke effecten van orthopedagogische muziekbeoefening-lessen op het executief functioneren van kinderen in de leeftijd van 6 tot 9 jaar binnen het (speciaal) basisonderwijs te onderzoeken uiteengezet en gemotiveerd. Het mixed methods design wordt beschreven, waarbij zowel kwalitatieve en kwantitatieve onderzoeksmethoden worden aangewend om de meerwaarde van orthopedagogische muziekbeoefening binnen deze complexe onderwijscontext te verkennen. Theoretische en praktische implicaties van voorgestelde methodologie worden besproken.

Hoofdstuk 5 richt zich op de vraag hoe muziekonderwijs in het (speciaal) basisonderwijs in Nederland wordt aangeboden en op mogelijke factoren die hierop van invloed zijn. Hiervoor werd een observationele studie opgezet waarbij 16 muzieklessen zijn geobserveerd op twee reguliere basisscholen en drie scholen voor speciaal basisonderwijs over een periode van tien maanden. Het observatieschema was gebaseerd op de uitkomsten van de in hoofdstuk 3 genoemde focusgroepen. Observaties werden vervolgens getranscribeerd en geanalyseerd. Resultaten lieten overeenkomsten tussen scholen zien in termen van (1) participatie van het kind, (2) de lengte van de muzikale activiteit en (3) de non-verbale communicatie van docenten. Verschillen tussen scholen werden waargenomen in termen van (1) de 
muzikale materialen en de beschikbare ruimte voor muziekonderwijs, (2) het plezier, de verwachtingen en de mogelijkheid tot eigen inbreng van het kind, (3) de muzikale domeinen die aan bod komen in de les, de variatie en herhaling van activiteiten en de manier waarop deze onderling met elkaar verbonden zijn en worden uitgebreid, (4) de attitude en de muzikale vaardigheden van de docent en (5) de gehanteerde didactiek. Aan de hand van de observaties konden ook een aantal best practices worden geïdentificeerd, namelijk (1) de docent die diepgaande muzikale kennis bezit, zoals bleek uit zijn/haar vermogen om te improviseren en kinderen muzikaal te kunnen begeleiden, (2) diepgaande kennis over de ontwikkeling van kinderen zoals werd waargenomen in het interpreteren van en het afstemmen op signalen van het kind en (3) grondige kennis van (ortho)didactiek, zoals werd geobserveerd in het vormgeven van (muzikale) activiteiten afgestemd op de sterktes en zwaktes van een kind als ook de algemene muzikale doelen. Alle bovengenoemde elementen werden geobserveerd in de orthopedagogische muziekbeoefening-lessen. Observaties lieten ook potentiële positieve effecten zien op het gebied van expressie en executieve functies bij kinderen die deze lessen volgden.

Hoofdstuk 6 beschrijft een pilotstudie. In een quasi-experimenteel design werd de mogelijke invloed van orthopedagogische muziekbeoefening op het executief functioneren van kinderen met speciale onderwijsbehoeften onderzocht. Van 60 kinderen (6-9 jaar), afkomstig van vijf verschillende scholen voor regulier en speciaal basisonderwijs, werden gedurende één schooljaar vier maal data met betrekking tot het executief functioneren verzameld. Zesentwintig kinderen in de orthopedagogische muziekbeoefening groep volgden wekelijks orthopedagogische muziekbeoefeninglessen als onderdeel van het school curriculum, terwij 34 kinderen in de reguliere groep hun gebruikelijke muziekles volgden. Drie domeinen van executieve functies werden geëvalueerd, te weten cognitieve flexibiliteit, werkgeheugen en aandacht. Er werden multilevel analyses uitgevoerd. Analyses lieten verschillende patronen van executief functioneren over de tijd zien voor reguliere basisscholen en scholen voor speciaal basisonderwijs. Er werden geen significante verschillen gevonden met betrekking tot het executief functioneren tussen kinderen die orthopedagogische muziekbeoefening-lessen volgden en kinderen die reguliere muzieklessen volgenden. Ondanks het uitblijven van significante resultaten toont deze studie de haalbaarheid aan om een longitudinale studie op te zetten om de meerwaarde van orthopedagogische muziekbeoefening te verkennen. Daarnaast biedt de studie inzicht in specifieke uitdagingen, die als aanbevelingen voor toekomstig onderzoek dienen. 
Hoofdstuk 7 omvat de algemene discussie van dit proefschrift. Eerst worden de belangrijkste onderzoeksresultaten besproken en geïntegreerd binnen de context van het geïntegreerde biopsychosociaal model. Onderwerpen die worden geëvalueerd zijn onder meer de biologische, psychologische, interpersoonlijke en contextuele factoren en hun interacties die relevant zijn voor het begrijpen van de potentie van orthopedagogische muziekbeoefening. Vervolgens worden deze gegevens besproken vanuit een onderwijskundig perspectief. Methodologisch sterke punten en beperkingen worden beschouwd, in het bijzonder de theoretische en praktische aspecten van de kwalitatieve en kwantitatieve studies. Hierdoor is een bredere kijk op het onderzoek naar orthopedagogische muziekbeoefening mogelijk. Tenslotte zijn er aanbevelingen voor toekomstig onderzoek en de praktijk. 
VALORISATIE

\section{Referenties}

Rutten, M., \& Stuijts, M. (2014). Muziekstrategie. Maastricht, Nederland: Conservatorium Maastricht. 


\section{VALORISATIE}

Orthopedagogische muziekbeoefening is een manier van handelen binnen een muziekeducatieve dan wel -vormende pedagogische situatie waarin de muzikale ontwikkeling van een kind wordt gestimuleerd en tegelijkertijd muzikale participatie wordt gebruikt om te werken aan doelstellingen op sociaal-emotioneel, cognitief en/of sensomotorisch gebied (Rutten \& Stuijts, 2014). De meerwaarde van orthopedagogische muziekbeoefening-lessen voor kinderen binnen het speciaal basisonderwijs, specifiek op het vlak van executieve functies, is in deze dissertatie onderzocht. De resultaten die zijn verkregen, zijn relevant voor zowel de opleiding als voor de praktijk. Het valorisatie-addendum bespreekt achtereenvolgens de relevantie voor de praktijk van orthopedagogische muziekbeoefening, kennisdeling in de (onderwijs)praktijk en het belang van samenwerking in de praktijk.

\section{Relevantie voor praktijk van orthopedagogische muziekbeoefening}

Orthopedagogische muziekbeoefening vindt plaats binnen verschillende werkvelden waaronder het speciaal (basis)onderwijs. Binnen deze tak van het onderwijs hebben zich verschillende veranderingen voltrokken. De meest belangrijke verandering is de invoering van Passend onderwijs in 2014. Dit proefschrift biedt nieuwe inzichten en aanknopingspunten waarmee orthopedagogische muziekbeoefening kan inspelen op de actualiteit van deze veranderde onderwijscontext.

Het uitgangspunt van passend onderwijs is dat reguliere scholen een adaptief onderwijsaanbod kunnen bieden voor elke leerling die op school wordt aangemeld. Alleen wanneer de (onderwijs)situatie van een leerling te complex is voor een reguliere school en deze zelf geen passend onderwijs kan bieden, zoekt de school een plek die deze zorg wel kan bieden. In de praktijk blijven kinderen met leer- en/of gedragsproblemen echter lang(er) op de reguliere basisschool (van der Helm, 2020), met als gevolg dat het kind niet altijd de begeleiding krijgt die het nodig heeft. Langer blijven op de basisschool legt druk op een klas; er zitten leerlingen met uiteenlopende hulpvragen. Leraren komen binnen de reguliere setting niet altijd toe aan het aanpassen van hun werkwijze op deze leerlingen. Daarnaast bezitten leraren niet altijd voldoende kennis om om te gaan met de diverse leer- en gedragsproblemen (van der Helm, 2018). Binnen het speciaal basisonderwijs worden eveneens veranderingen gesignaleerd, waaronder een toename in gedragsproblemen bij leerlingen (de Boer, 2020). 
Gezien de verdichting van de problematiek en een groeiende heterogeniteit van de leerlingenpopulatie, zowel binnen het reguliere basisonderwijs als binnen het speciaal basisonderwijs, wordt devraag naar adequate,(meer)complexe onderwijsondersteuning groter. Binnen beide onderwijssituaties kan orthopedagogische muziekbeoefening van grote waarde zijn doordat er in de lessen aan verschillende ontwikkelingsdomeinen wordt gewerkt en de verwachtingen van elk kind afzonderlijk vertaald kunnen worden in een of meerdere doelen op bijvoorbeeld het gebied van het concentratievermogen, het uitbreiden van de woordenschat of het zelfvertrouwen. Orthopedagogische muziekbeoefening biedt veel mogelijkheden om te differentiëren door het aanpassen van muzikaal domein, instructie, tempo, materiaal, uitvoering en/of verwerking, zodat een kind op zijn of haar eigen niveau kan worden aangesproken. Vanuit de muziek en het orthopedagogisch perspectief kan er binnen orthopedagogische muziekbeoefening aandacht worden gericht op meerdere aspecten van de ontwikkeling van het kind, zoals muzikale, cognitieve en emotionele aspecten.

Wileen kind opschoolkunnenfunctionerenentotlerenkomen, dan moethetaan bepaalde voorwaarden voldoen. Algemene leervoorwaarden verwijzen ontwikkelingsfactoren die van belang zijn en invloed hebben op schoolse leerprestaties van een kind (Verheij \& van Doorn, 2002). Deze factoren hebben betrekking op de lichamelijke ontwikkeling van een kind zoals de gezondheid, de (ontwikkeling van) motoriek en waarneming, de cognitieve ontwikkeling, waaronder het concentratievermogen, het geheugen, de taal, de visuele/auditieve waarneming, het vermogen tot planmatig werken en informatie te organiseren, de sociale en emotionele ontwikkeling, zoals het functioneren met andere kinderen, het kunnen samenwerken en zich aanpassen aan de geldende regels, de relatievorming van het kind met andere kinderen en de afstemming tussen kind en leerkracht. Naast bovengenoemde factoren spelen aspecten als de relatievorming met ouders en de mate waarin een leerkracht in staat is passend onderwijs te verzorgen afgestemd op het leerniveau van het kind een belangrijke rol. De relaties van het kind met andere kinderen en de afstemming tussen kind en leerkracht zijn eveneens van belang. Naast bovengenoemde factoren blijkt de omgeving meebepalend i.c. de relatievorming met ouders en de mate waarin een leerkracht in staat is passend onderwijs te verzorgen afgestemd op het leerniveau van het kind.

Orthopedagogische muziekbeoefening kan een belangrijke bijdrage leveren aan het stimuleren van leervoorwaarden die bijdragen aan de (schoolse) ontwikkeling van een kind. Door middel van verschillende zang-, bewegings- en/of instrumentale activiteiten 
kan de fijne- en/of grove motoriek gestimuleerd worden. Het stimuleren van het ritmegevoel en toonhoogte kan helpen bij het onderscheiden van verschillende klanken in taal. Het zingen en het herhalen van liedjes stimuleren de woordenschat, auditieve waarneming en verbale geheugen. Daarnaast kunnen orthopedagogische muziekbeoefening-lessen bijdragen aan de ontwikkeling van sociale en emotionele vaardigheden i.c. zichzelf leren uiten, het benoemen en ervaren van gevoelens, samenwerken om iets te bereiken, wachten op een beurt, naar elkaar luisteren of alleen durven spelen voor een groep. Een bijkomend voordeel is dat een kind deze lessen niet als therapie of onderwijs lijkt te ervaren, waarbij expliciete aandacht is voor minder ontwikkelde vaardigheden en deze nadrukkelijk geoefend worden.

De orthopedagogische muziekbeoefening-lessen kunnen een positieve invloed hebben op cognitieve vaardigheden waaronder executieve functies, zoals concentratievermogen, geheugen, flexibiliteit en planning. Deze vaardigheden zijn van groot belang bij het aansturen van gedrag en bij het leren en het functioneren op school, waar een kind steeds nieuwe dingen leert, moet samenwerken en kritisch leert denken. Wetenschappelijk onderzoek onderstreept het belang van executieve functies bij leerprocessen en schoolprestaties van kinderen (Fuhs, Farran \& Nesbitt, 2015; Nelson et al., 2017; Zelazo, Blair \& Willoughby, 2016; Nguyen \& Duncan, 2019). Bevindingen in dit proefschrift laten het belang van deze functies zien binnen een orthopedagogische muziekbeoefening-les in relatie tot muziekonderwijs op school. Deze zijn in focusgroepen ter sprake gebracht waarbij door respondenten een positieve invloed van orthopedagogische muziekbeoefening op deelaspecten van executieve functies zijn genoemd. Vanuit de observaties van orthopedagogische muziekbeoefening-lessen lijkt de manier waarop activiteiten worden vormgegeven aspecten van executief functioneren te stimuleren. Observaties toonden aan dat muzikale activiteiten vaker werd herhaald, uitgebreid en/of gevarieerd, hetgeen het werkgeheugen en de flexibiliteit bij kinderen zou kunnen bevorderen.

Het geïntegreerde biopsychosociaal model werd in dit proefschrift in aangepaste vorm, toegepast op orthopedagogische muziekbeoefening. Dit biedt de mogelijkheid om vanuit verschillende perspectieven te beschouwen en te begrijpen hoe de verschillende biologische, psychologische en interpersoonlijke factoren en de context voortdurend op elkaar inspelen. Biologische factoren staan voor de verschillende hersengebieden die betrokken zijn bij muzikaal leren. Psychologische factoren representeren verschillende cognitieve vaardigheden waar in een orthopedagogische muziekbeoefening-les een 
beroep op wordt gedaan. Interpersoonlijke factoren weerspiegelen interacties tussen de orthopedagogisch muziekbeoefenaar, het kind, de muziek en de klasgenoten waarmee gemusiceerd wordt. De elementen die onder context worden geschaard betreffen o.a. het materiaal, de ruimte en groepsdynamiek tijdens de orthopedagogische muziekbeoefening-les. Het model maakt zichtbaar dat bij het ontstaan en/of voortbestaan van bepaald gedrag van een kind binnen de orthopedagogische muziekbeoefeningles meerdere factoren een rol kunnen spelen en specifieke (muzikale) aanpassingen, passend bij zijn of haar ontwikkeling, worden verlangd.

Door oog te hebben voor deze (wisselwerking tussen) verschillende factoren kan orthopedagogisch muziekbeoefening vanuit meerdere perspectieven een bijdrage leveren aan de ontwikkeling van een kind, niet alleen binnen het speciaal basisonderwijs maar (juist) ook binnen het reguliere basisonderwijs.

\section{kennisdeling in de (onderwijs)praktijk en wetenschap}

De uitkomsten van de studies in dit proefschrift zijn met verschillende betrokkenen gedeeld en op verschillende manieren in de praktijk gedeeld. Zo zijn bevindingen besproken met docenten en studenten van de opleiding orthopedagogisch muziekbeoefening en met de meewerkende scholen. De resultaten van de verschillendestudieszijninvakliteratuur enwetenschappelijkeliteratuurgepubliceerd of worden nog gepubliceerd. Daarnaast zijn er verschillende presentaties van de onderzoeksbevindingen gegeven op een internationaal congres, symposia en verschillende bijeenkomsten. Onderzoeksbevindingen kunnen worden geïntegreerd in het curriculum van de opleiding orthopedagogische muziekbeoefening, in de vorm van het toevoegen van het aangepaste biopsychosociale model met nieuwe (neuro)wetenschappelijke inzichten aan de bestaande kennisbronnen over orthopedagogische muziekbeoefening. Integratie in het reeds bestaande curriculum draagt bij aan het vergroten van de reeds aanwezige kennis en vaardigheden, het evalueren en eventueel bijstellen van inzichten en verdere verkenning van handelingswijzen van studenten orthopedagogische muziekbeoefening. Verworven inzichten kunnen tevens worden toegepast in nascholing, door nieuwe inzichten en vertaling naar onderliggende handelingswijzen kunnen orthopedagogisch muziekbeoefenaars ervaringen opdoen, ervaringen uitwisselen en op die manier bijdragen aan de ontwikkeling van het vakgebied. De focus van dit proefschrift lag 
op de meerwaarde van orthopedagogische muziekbeoefening binnen het speciaal basisonderwijs. Orthopedagogische muziekbeoefening wordt echter in verschillende werkvelden toegepast, bijvoorbeeld in de kinder- en jeugdpsychiatrie, in de zorg voor mensen met een verstandelijke beperking, verpleeghuiszorg of het voortgezet speciaal onderwijs. Wat orthopedagogische muziekbeoefening bij verschillende doelgroepen en in verschillende settings kan bijdragen, zijn interessante vragen om verder te onderzoeken. Op die manier kan een meer coherent beeld worden gevormd van de meerwaarde van orthopedagogische muziekbeoefening en (potentiële) factoren van invloed.

\section{Het belang van samenwerking in de praktijk}

$\mathrm{Er}$ is in toenemende mate aandacht voor executieve functies binnen het (basis) onderwijs. De impact van (problemen met) executieve functies wordt steeds meer erkend en herkend. Voor de groepsleerkracht is (methodisch) materiaal voorhanden om deze functies te versterken, variërend op het niveau van instructies voor planning tot de inrichting van het klaslokaal. Door aandacht te besteden aan het gericht oefenen van specifieke zwakke executieve functies kan een groepsleerkracht een kind helpen bij het ontwikkelen c.q. versterken van deze functies en het verminderen van angst en onzekerheid (Dawson \& Guare, 2011). Samenwerking met betrokken collega's is hierbij essentieel aangezien er geen gestandaardiseerd plan van aanpak voorhanden is. Het ondersteunen van een kind met zwakke executieve functies vraagt daarentegen om een gedeelde, responsieve aanpak waarbij problemen c.q. moeilijkheden die een kind ervaart, worden opgevolgd en zoveel mogelijk ondervangen.

Een orthopedagogisch muziekbeoefenaar is in staat om de les muzikaal zodanig in te richten dat hij of zij eveneens een bijdrage kan leveren aan het doelgericht stimuleren van executieve functies (zoals blijkt uit de voorbeelden die hieronder worden genoemd). Door een orthopedagogisch muziekbeoefenaar (nog meer) te betrekken bij het individuele leerplan van een kind en door wederzijdse afstemming met de groepsleerkracht aangaande specifieke ondersteuningsbehoeften op het vlak van executief functioneren, kan tegenmoet worden gekomen aan de individuele begeleiding en onderwijsbehoeften van een kind op school.

De leerlingen zitten op hun stoel en de orthopedagogisch muziekbeoefenaar vraagt hen de ogen te sluiten. Vervolgens neemt de orthopedagogisch muziekbeoefenaar een triangel, 
loopt door de ruimte en laat de triangel op verschillende plekken klinken. Vervolgens openen de leerlingen de ogen. Eén van hen mag vervolgens met de triangel door de ruimte lopen en deze laten klinken op dezelfde punten in de ruimte. Met deze activiteit wordt onder meer de aandacht gestimuleerd (geconcentreerd blijven op de taak), het werkgeheugen (onthouden uit welk punt van de ruimte het geluid komt) en de inhibitie (ogen gesloten houden). Bij een andere activiteit laat de orthopedagogisch muziekbeoefenaar de leerlingen rondom een trommel staan. Hij of zij heeft stokken vast. Pas als de orthopedagogisch muziekbeoefenaar een stok op de trommel laat vallen, mogen de leerlingen klappen. Bij deze activiteit trainen leerlingen aandacht (opletten wanneer de stok gaat vallen), werkgeheugen (op tijd klappen) en inhibitie (niet klappen als er geen stok valt). Een derde voorbeeld is een activiteit waarbij de orthopedagogisch muziekbeoefenaar verschillende leerlingen een xylofoon met 1 klankstaaf geeft. De docent laat vervolgens een schema zien met de volgorde waarin de noten gespeeld worden, waarbij telkens maar 1 noot mag klinken. Vervolgens verandert de docent het schema, waarbij de reeks niet van voren naar achteren wordt gespeeld maar andersom. Deze activiteit vraagt wederom aandacht (gericht blijven op het schema), werkgeheugen (leerling moet onthouden welke noot hij of zij moet spelen), inhibitie (niet spelen als er andere noten klinken) en flexibiliteit (uitvoering aanpassen aan een veranderd schema). (Packbier, persoonlijke communicatie, 24 oktober 2020).

Een orthopedagogisch muziekbeoefenaar mag, door zijn of haar brede muzikale basis, kennis van normale en atypische kindontwikkeling en (ortho)didactiek, ook binnen een multidisciplinair overleg als volwaardige gesprekspartner worden beschouwd. Door gerichte observaties en weloverwogen keuzes in de focus op een bepaald ontwikkelingsdomein en concrete doelen, die vervolgens vertaald worden naar keuzes voor een of meerdere muzikale domein(en) en activiteiten, didactiek en pedagogisch klimaat, kan binnen orthopedagogische muziekbeoefening-les, spelenderwijs, gewerkt worden aan uitbreiding en stimulering van vaardigheden. Vanuit deze vakinhoudelijke deskundigheid kan een orthopedagogisch muziekbeoefenaar binnen een multidisciplinair overleg bijdragen aan het gepersonaliseerd stimuleren van de ontwikkeling van leren en gedrag van een kind. 


\section{Referenties}

Dawson, P., \& Guare, R. (2011). Slim maar... Help kinderen hun talenten benutten door hun executieve functies te versterken. Amsterdam: Hogrefe.

De Boer, A. (2020). Evaluatie passend onderwijs. Sectorrapport speciaal onderwijs. Groningen: Rijksuniversiteit Groningen.

Fuhs, M.W., Farran, D.C., \& Nesbitt, K.T. (2015). Prekindergarten children's executive functioning skills and achievement gains: the utility of direct assessments and teacher ratings. Journal of Educational Psychology, 107(1), 207-221.

Nelson, T. D., Nelson, J. M., James, T. D., Clark, C. A., Kidwell, K. M., \& Espy, K. A. (2017). Executive control goes to school: Implications of preschool executive performance for observed elementary classroom learning engagement. Developmental psychology, 53(5), 836-844. DOI: $10.1037 /$ dev0000296.

Nguyen, T., \& Duncan, G. J. (2019). Kindergarten components of executive function and third grade achievement: A national study. Early Childhood Research Quarterly, 46, 49-61. DOI:10.1016/j.ecresq.2018.05.006.

Rutten, M., \& Stuijts, M. (2014). Muziekstrategie. Maastricht, Nederland: Conservatorium Maastricht.

Van der Helm, G.H.P. (2020). Evaluatie van de wet passend onderwijs: wat is niet waargemaakt en waarom niet? Retrieved from http://www.hsleiden.nl/residentiele-jeugdzorg/publicaties/ publicaties

Van der Helm, G.H.P., \& Lindemulder, J. (2018). Weeffouten in de wet Passend Onderwijs. Retrieved from http://www.sociale vraagstukken.nl/weeffouten-in-de-wet-passendonderwijs/Verheij, F., \& van Doorn, E.C. (2002). Ontwikkeling en leren: Psychiatrie op school. Assen: Koninklijke Van Gorcum.

Zelazo, P. D., Blair, C. B., \& Willoughby, M. T. (2016). Executive function: Implications for education (No. NCER 2017-2000). Washington, DC: National Center for Education Research, Institute of Education Sciences, U.S. Department of Education. 


\title{
Dankwoord
}

\section{The little things? The little moments? They aren't little}

\author{
John Kabat-Zinn
}

Promoveren doe je niet alleen, een leuke en leerzame tijd hebben al helemaal niet. Daar wil ik iedereen voor bedanken en een aantal mensen in het bijzonder.

Allereerst mijn grote dank aan de leerlingen, de ouders van leerlingen, de leerkrachten, de vakleerkrachten en de directeuren van de deelnemende scholen, die tussen alle drukte door al die testen hebben voltooid, vragenlijsten hebben ingevuld en hun muzieklessen opstelden voor observaties. Zonder jullie medewerking en inzet zou er helemaal geen onderzoek zijn.

Prof. dr. F.J. M. Feron, beste Frans, ik ben je dankbaar voor de manier waarop jij mij door dit promotietraject geloodst hebt. Dank je wel dat ik zo veel van je mocht leren. In die jaren hebben we veel overlegd en gepraat; niet alleen over het onderzoek, maar ook over muziek en of piano spelen wel of niet moeilijker is dan promoveren (daar zijn de meningen nog steeds over verdeeld). Bedankt voor je enthousiasme, humor, scherpe beschouwingen waardoor ik alles weer in de juiste context kon plaatsen, deskundige begeleiding, maar bovenal het vertrouwen.

Prof. dr. S.A.H. van Hooren, beste Susan, als ik door de bomen het bos niet meer zag, was jij mijn routeplanner. Dankzij jouw begeleiding, opbouwende feedback, concrete aanwijzingen en geduldige uitleg voelde ik me gesteund in het hele traject. Bijzonder is de manier waarop jij schijnbaar zonder moeite met een aantal zinnen of aanpassingen een artikel 'af' kan maken. Ik vond het een voorrecht om als promovenda met jou samen te werken. 
Dr. E.V. Syurina, beste Elena, zonder jou was dit nooit wat geworden. Jij weet als geen ander dat er bij het schrijven van dit proefschrift mooie en ook moeilijkere momenten zijn geweest. Door jouw inzet en steun kon dit een afgerond geheel worden. Bedankt voor het delen van lief en leed op promotie- en niet-promotiegebied.

Dr. M. Stuijts, beste Miriam, je kennis, ervaringen en vaardigheden maken jou tot een onderzoeker waar iedereen veel van kan leren. Samen hebben we vele uren gewerkt aan de opzet en het coderen. Dank voor al je hulp.

De leden van de leescommissie, Prof. dr. T.A.M.J. van Amselsvoort, Prof. dr. J. Jolles, Prof. dr. X. M. H. Moonen en Prof. dr. C. M. van Heugten dank ik voor de tijd besteed aan het lezen en kritisch beoordelen van het manuscript.

Mare de Groote, directeur van conservatorium Maastricht, Zuyd Hogeschool en Marc Rutten, bij start van het onderzoek hoofd opleiding Docent Muziek, dank ik voor de mogelijkheden die jullie en de opleiding hebben gecreëerd om dit promotieonderzoek uit te voeren.

Anne Schreurs en Charelle Campagne, in het kader van jullie afstudeerproject voor de master psychologie aan de UM hebben jullie voor mijn onderzoek vele testen afgenomen en onderzoeksgegevens verzameld. Dank voor jullie inzet en nauwkeurigheid.

Ik bedank ook Yolande Eymael, Annick Keehnen, Lars van den Oever, Sielke Smeets, Karel Verlaek, Maud Lemmens, Eveline Struelens, Suzan Hambuckers en Joyce Strijbos voor hun deelname aan de focusgroepen. Dank voor jullie bereidwilligheid en openheid. Ik heb veel van jullie geleerd.

Dank aan dr. Peter Verboon voor de geboden statische hulp en bijdrage aan de totstandkoming van het artikel over de pilot studie.

Dr. Petra Hurks, dank voor alle adviezen rondom de neuropsychologische onderzoeken. Leon Packbier, dank je wel voor alle antwoorden op mijn praktische vragen.

Collega's van de opleiding Docent Muziek van Conservatorium Maastricht wil ik bedanken voor hun interesse, feedback, geduld, begrip, inspiratie en fijne samenwerking.

Dank aan Ione Haddock en Rachel Brenner voor hun controle op de Engelse taal en waardevolle adviezen, aanvullingen en correcties.

Lieve vriendinnen uit Maastricht en daarbuiten, dank voor jullie interesse, geduld, steun en plezier tijdens het lange promotietraject. 
Papa en mama, bedankt voor jullie vertrouwen in mijn kunnen en alle mogelijkheden die jullie mij hebben geboden. Zonder jullie zou dit proefschrift niet bestaan.

Trix en Ruud, bedankt voor vele oppasuren hetgeen mij in staat stelde om dit onderzoek af te ronden.

Jasmina, Nové, Charissa, Robin, Thorsten, dank voor jullie betrokkenheid.

Berry en Jolanda, dank je wel dat jullie mijn paranifm willen zijn.

Björn, met je engelengeduld, humor en relativeringsvermogen heb je een onmisbare bijdrage geleverd aan dit proefschrift. Door en met jou ben ik gelukkig.

Olivia en Nina, mijn lieve meisjes. Tijdens het promotietraject kwamen jullie om de hoek kijken en plaatsten alles in perspectief. 


\section{CURRICULUM VITAE}

Elisabeth Hubertina Dumont was born on June 26th 1980 in Heerlen, the Netherlands. After obtaining her Gymnasium diploma at the Bernardinus college in Heerlen in 1998, she studied developmental psychology and neuropsychology at Maastricht University. After graduation in 2003, she started working as a psychologist in special primary education, and at Virenze, an institution for Outpatient Mental Healthcare, focusing on children with behavioural and/or learning disabilities. In 2011, she obtained a Master's degree in Piano Accompaniment/Instrumental \& Vocal Coaching. In 2012, she started as a lecturer at the Music in Education department, Conservatorium Maastricht, Zuyd University of Applied Sciences and also started her PhD project. Her main aim was to explore the relationship between Special Music Education $(\mathrm{OMB})$ and the development of executive functions in children (aged 6-9) in special and mainstream primary education. The research was conducted in collaboration with KenVaK, research centre for arts therapies, Maastricht University, Faculty of health, medicine and life sciences and Vrije Universiteit Amsterdam, Athena Institute. Elisabeth lives with her partner and two children in Woerden, the Netherlands. 


\section{PUBLICATIONS}

\section{Present thesis:}

Chapter 2: Dumont, E., Syurina, E. V., Feron, F., \& Van Hooren, S. (2017). Music Interventions and Child Development: A Critical Review and Further Directions. Frontiers in psychology, 8, 1694.

Chapter 3: Dumont, E., van Hooren, S., Stuijts, M. \& Feron, F. (2015). Orthopedagogische muziekbeoefening: een opmaat voor een nieuw perspectief? [Dutch article]. Tijdschrift voor Orthopedagogiek, 54, 373-383.

Chapter 4: Dumont, E., Feron, F., Stuijts, S., Syurina, E.V., \& Van Hooren, S. (2015). Special music education and executive functioning: design of a practice-based research (submitted for publication).

Chapter 5:Dumont, E., Syurina, E.V., Feron, F. \& Van Hooren, S. (2018). Beyond the sound of music: an observational study exploring the challenges of music education (submitted for publication).

Chapter 6:Dumont, E., Verboon, P., Syurina, E.V., Feron, F. \& Van Hooren, S. (2019). Exploring the effect of special music education on executive functioning in children with special educational needs: a pilot study (submitted for publication).

\section{Presentations}

Orthopedagogische Muziekbeoefening in het speciaal onderwijs. Presentatie "symposium opleiding docent muziek, conservatorium Maastricht", Maastricht, Nederland (oktober 2012).

Taalontwikkeling en muziekeducatie. Presentatie "symposium opleiding docent muziek, conservatorium Maastricht", Maastricht, Nederland (mei 2014).

Orthopedagogische muziekbeoefening en executieve functies. Presentatie "symposium opleiding docent muziek, conservatorium Maastricht", Maastricht, Nederland (maart 2019).

Special Music Education: a Prelude to a new Perspective? Presentatie "EUSUHM Congress", Rotterdam, Nederland (september 2019).

Useful or not? A critical review of effects of music interventions on child development. Posterpresentatie "EUSUHM Congress", Rotterdam, Nederland (september 2019).

Beyond the sound of music: an observational study exploring the challenges of music education. Posterpresentatie "EUSUHM Congress", Rotterdam, Nederland (september 2019). 
